\title{
Review
}

\section{Biofuel cells and their development}

\author{
R.A. Bullen ${ }^{\text {a }}$, T.C. Arnot ${ }^{\text {b }}$, J.B. Lakeman ${ }^{\text {c }}$, F.C. Walsh ${ }^{\mathrm{a}, *}$ \\ ${ }^{a}$ Engineering Chemistry Group, School of Engineering Sciences, University of Southampton, Highfield, Southampton SO17 1BJ, United Kingdom \\ ${ }^{\mathrm{b}}$ Department of Chemical Engineering, University of Bath, Claverton Down, Bath BA2 7AY, United Kingdom \\ ${ }^{\mathrm{c}}$ Power Sources and Energy Storage Team, Physical Sciences Department, Dstl, Porton Down, Salisbury, Wiltshire SP4 OQR, United Kingdom
}

Received 20 October 2005; received in revised form 26 January 2006; accepted 26 January 2006

\begin{abstract}
This review considers the literature published since 1994 on microbial and enzymatic biofuel cells. Types of biofuel cell are classified according to the nature of the electrode reaction and the nature of the biochemical reactions. The performance of fuel cells is critically reviewed and a variety of possible applications is considered. The current direction of development of biofuel cells is carefully analysed. While considerable chemical development of enzyme electrodes has occurred, relatively little progress has been made towards the engineering development biofuel cells. The limit of performance of biofuel cells is highlighted and suggestions for future research directions are provided.
\end{abstract}

(C) 2006 Elsevier B.V. All rights reserved.

Keywords: Biofuel cell; Enzymatic fuel cell; Microbial fuel cell; Enzyme electrode

\section{Contents}

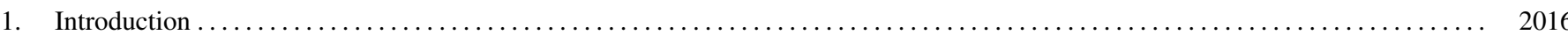

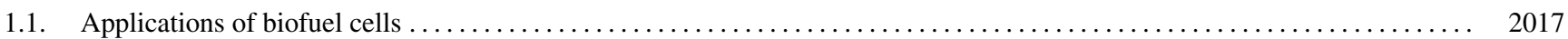

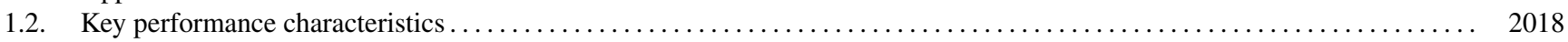

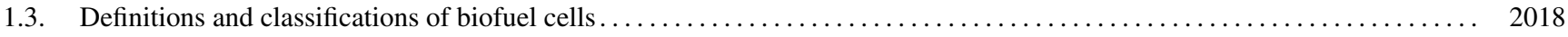

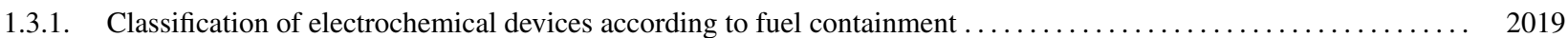

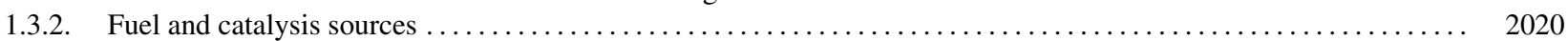

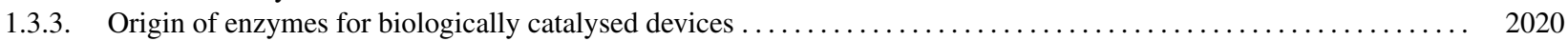

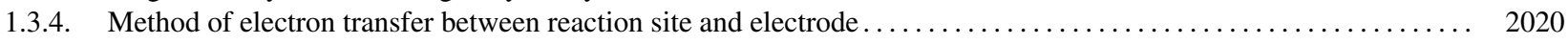

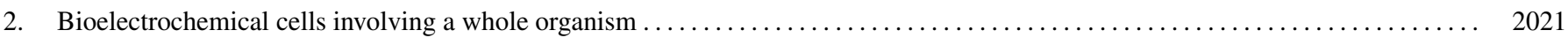

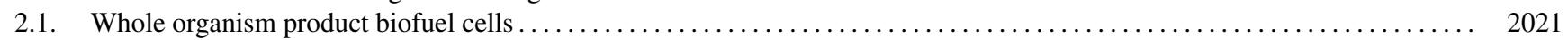

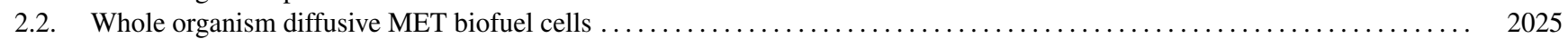

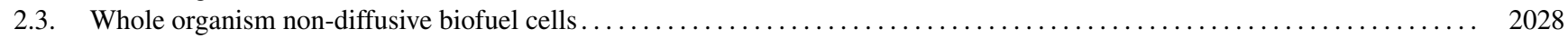

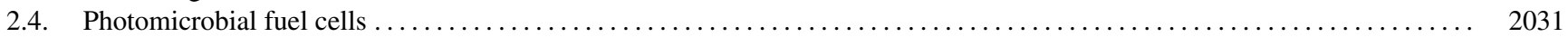

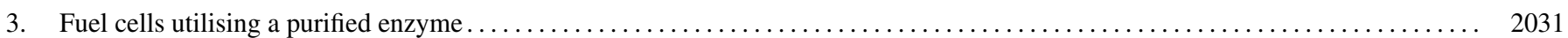

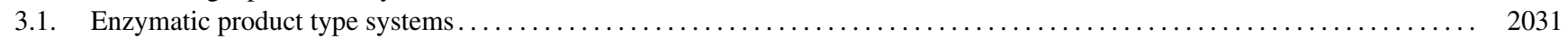

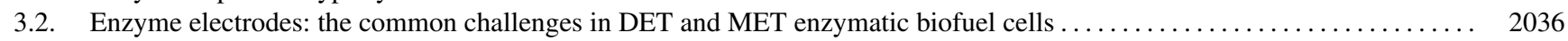

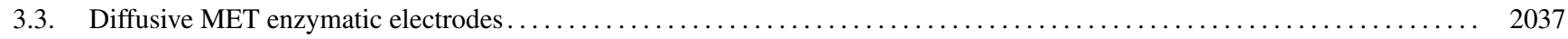

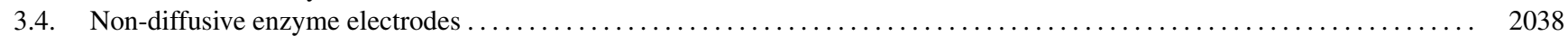

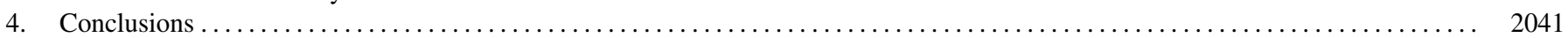

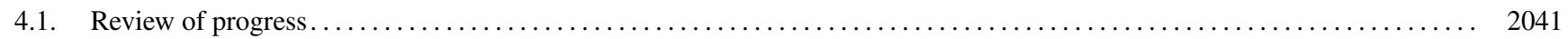

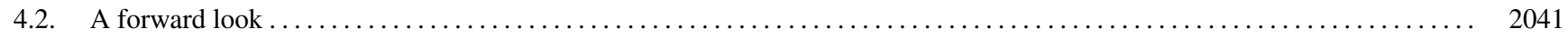

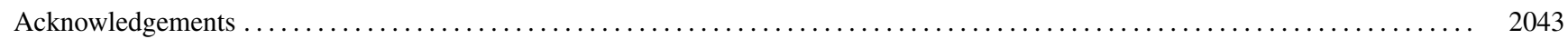

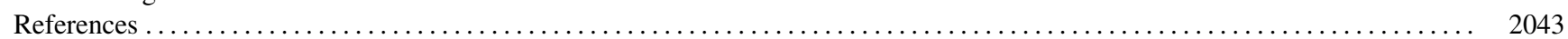

* Corresponding author. Tel.: +44 2380598 752; fax: +44 2380598754.

E-mail address: F.C.Walsh@ soton.ac.uk (F.C. Walsh). 


\begin{tabular}{|c|c|}
\hline \multicolumn{2}{|c|}{ Nomenclature } \\
\hline$A$ & geometric area of electrode $\left(\mathrm{cm}^{2}\right)$ \\
\hline$A_{\mathrm{e}}$ & area of electrode per unit volume $\left(\mathrm{cm}^{2} \mathrm{~cm}^{-3}\right)$ \\
\hline$c_{i}$ & concentration of species $i\left(\mathrm{~mol} \mathrm{dm}^{-3}\right)$ \\
\hline E & $\begin{array}{l}\text { electrode potential versus a reference electrode } \\
\text { (V) }\end{array}$ \\
\hline$E_{\text {cell }}$ & cell potential $(\mathrm{V})$ \\
\hline$E_{\mathrm{e}}$ & equilibrium potential (V) \\
\hline$F$ & Faraday constant $\left(\mathrm{C} \mathrm{mol}^{-1}\right)$ \\
\hline$I$ & current (A) \\
\hline$j$ & current density $\left(\mathrm{A} \mathrm{cm}^{-2}\right)$ \\
\hline$k$ & $\begin{array}{l}\text { rate constant for a chemical reaction (first order } \\
\mathrm{s}^{-1} \text {, etc.) }\end{array}$ \\
\hline$k_{\max }$ & $\begin{array}{l}\text { maximum rate constant for an enzyme reaction } \\
\text { (first order } \mathrm{s}^{-1} \text {, etc.) }\end{array}$ \\
\hline$K_{\mathrm{m}}$ & Michaelis-Menten constant (mol) \\
\hline$m$ & mass $(\mathrm{g}$ or $\mathrm{kg})$ \\
\hline$P_{\text {cell }}$ & power output of cell (W) \\
\hline$R$ & molar gas constant $\left(\mathrm{J} \mathrm{K}^{-1} \mathrm{~mol}^{-1}\right)$ \\
\hline$R_{\mathrm{e}}$ & resistance $(\Omega)$ \\
\hline$t$ & time $(s)$ \\
\hline$T$ & temperature $(\mathrm{K})$ \\
\hline$V_{\mathrm{e}}$ & electrode volume $\left(\mathrm{cm}^{3}\right)$ \\
\hline$z$ & $\begin{array}{l}\text { number of electrons involved in electrode } \\
\text { reactions }\end{array}$ \\
\hline \multicolumn{2}{|c|}{ Greek symbol } \\
\hline$\eta$ & overpotential, $=E-E_{\mathrm{e}}(\mathrm{V})$ \\
\hline \multicolumn{2}{|c|}{ Subscripts } \\
\hline A & anode \\
\hline $\mathrm{C}$ & cathode \\
\hline $\mathrm{O}$ & oxidised species \\
\hline $\mathrm{R}$ & reduced species \\
\hline
\end{tabular}

\section{Introduction}

Biological fuel cells (biofuel cells) have been defined as fuel cells that rely on enzymatic catalysis for at least part of their activity (Palmore and Whitesides, 1994). A broader definition would consider biofuel cells as those fuel cells which use biocatalysts, which includes systems utilising non-enzyme proteins as well. In the broadest sense, we would define biological fuel cells are devices capable of directly transforming chemical to electrical energy via electrochemical reactions involving biochemical pathways.

The connection between biology and electricity has been known since the experiments of Galvani in the 1780s (Galvani, 1791), when it was discovered that current from a static electricity generator could cause a severed frog's leg to twitch, revolutionising the understanding of the nervous system. The fuel cell has been known for almost as long, since Grove successfully reversed the action of the electrolysis of water, recombining hydrogen and oxygen to produce water and electrical current (Grove, 1839). Given the early nature of these two discoveries it is perhaps surprising that a half cell using microorganisms was not demonstrated until 1910, when M.C. Potter, a professor of Botany at the University of Durham observed electricity production by $E$. coli (Potter, 1910). These results were not widely reported until the experiments of Cohen in 1931 who demonstrated a voltage greater than $35 \mathrm{~V}$ from microbial fuel cells connected in electrical series (Cohen, 1931).

The expansion of interest in fuel cells triggered by the USA space program, in the late 1950 s and early 1960 s, led to the development of microbial biofuel cells as a possible technology for a waste disposal system for space flights that would also generate power. Also in the late 1960s, the biofuel cell using cell-free enzyme systems began to be used, with the early goal of a power supply for a permanently implantable artificial heart (Kreysa et al., 1990; Wingard et al., 1982) and references within).

In a fuel cell, an oxidation reaction occurs at the anode and a reduction reaction at the cathode. The oxidation releases electrons, which travel to the cathode via the external circuit doing electrical work. The circuit is completed by the movement of a compensating charge through the electrolyte often in the form of positive ions.

Conventionally, fuel cells operate using relatively simple inorganic chemistries, taking such fuels as hydrogen or methanol $(\mathrm{MeOH})$, and producing energy, water and carbon dioxide (in the case of methanol). Other fuels, such as other lower order alcohols and alkanes, are also used, but they are frequently reformed to produce hydrogen before the fuel cell process (Mitsos et al., 2004; Vielstich et al., 2003).

Conventional fuel cells are regarded as 'low temperature' if they operate in the region of $80^{\circ} \mathrm{C}$ and typically require expensive p-group catalysts (Larminie and Dicks, 2000). A summary of the main types of inorganic fuel cell is presented in Table 1 .

Biofuel cells use enzymes as catalysts (alone or within an organism) and tend operate under mild conditions $\left(20-40^{\circ} \mathrm{C}\right.$,

Table 1

Inorganic fuel cell properties (after Larminie and Dicks, 2000)

\begin{tabular}{|c|c|c|c|}
\hline Type of fuel cell & Mobile ion & Operating temperature $\left({ }^{\circ} \mathrm{C}\right)$ & Application \\
\hline Proton exchange membrane (PEMFC) & $\mathrm{H}^{+}$ & $50-100$ & $\begin{array}{l}\text { Especially suitable for vehicles and mobile applications but also for low } \\
\text { power CHP systems }\end{array}$ \\
\hline Phosphoric acid (PAFC) & $\mathrm{H}^{+}$ & $\approx 220$ & Large numbers of $200 \mathrm{~kW}$ CHP systems in use \\
\hline Molten carbonate (MCFC) & $\mathrm{CO}_{3}{ }^{2-}$ & $\approx 650$ & Suitable for medium to large scale CHP systems up to MW capacity \\
\hline Solid oxide (SOFC) & $\mathrm{O}^{2-}$ & $500-1000$ & Suitable for all sizes of CHP systems, $2 \mathrm{~kW}$ to multi-MW \\
\hline
\end{tabular}


near-neutral $\mathrm{pH})$. These properties make biofuel cells an attractive development prospect for use in applications where generating high temperatures is difficult, or where harsh reaction conditions are undesirable. Biofuel cells are not, in theory at least, limited to these mild conditions as extremophile organisms or enzymes derived from them should be able to operate under a wide variety of reaction conditions. Also the variety of reactions able to be catalysed by enzymes makes the use of a much wider range of fuel substances possible (in some systems, up to the use of molecules as large as soluble starches). Biocatalysts, either protein, enzyme or whole organism, can also offer cost advantages over metallic catalysts, although this is not likely to be the case until the consumption of the enzyme is sufficient to merit large scale production. Widespread usage of a biocatalyst would however tend to lower the cost of producing it, while this is not true of transition metal catalysts. Previous review papers pertaining to biofuel cells or relevant similar technologies are summarised in Table 2. This paper seeks to collate descriptions and performance information for all biofuel cells reported since 1994.

\subsection{Applications of biofuel cells}

Presently there are two practically applied systems; a test rig operating on starch plant wastewater (microbial fuel cell system), which has been operating for at least 5 years has been demonstrated as a bioremediation method (Gil et al., 2003) and as a biological oxygen demand (BOD) sensor (Kim et al., 2003a), and also a biofuel cell has been employed as the stomach of a mobile robotic platform 'Gastronome', designed as the precursor to autonomous robots that can scavenge their fuel from their surroundings (gastrobots). The original Gastronome 'eats' sugar cubes fed to it manually (Wilkinson, 2000), but other groups have refined the concept somewhat to produce predators consuming slugs (Kelly and Melhuish, 2001), or flies (Ieropolous et al., 2004), although so far they both still require manual feeding. Many applications have been suggested however, and several of these are in varying stages of development.

The most obvious target for biofuel cells research is still for in vivo applications where the fuel used could be withdrawn virtually without limit from the flow of blood to provide a long-term

Table 2

Previous papers reviewing biofuel cells or related technologies

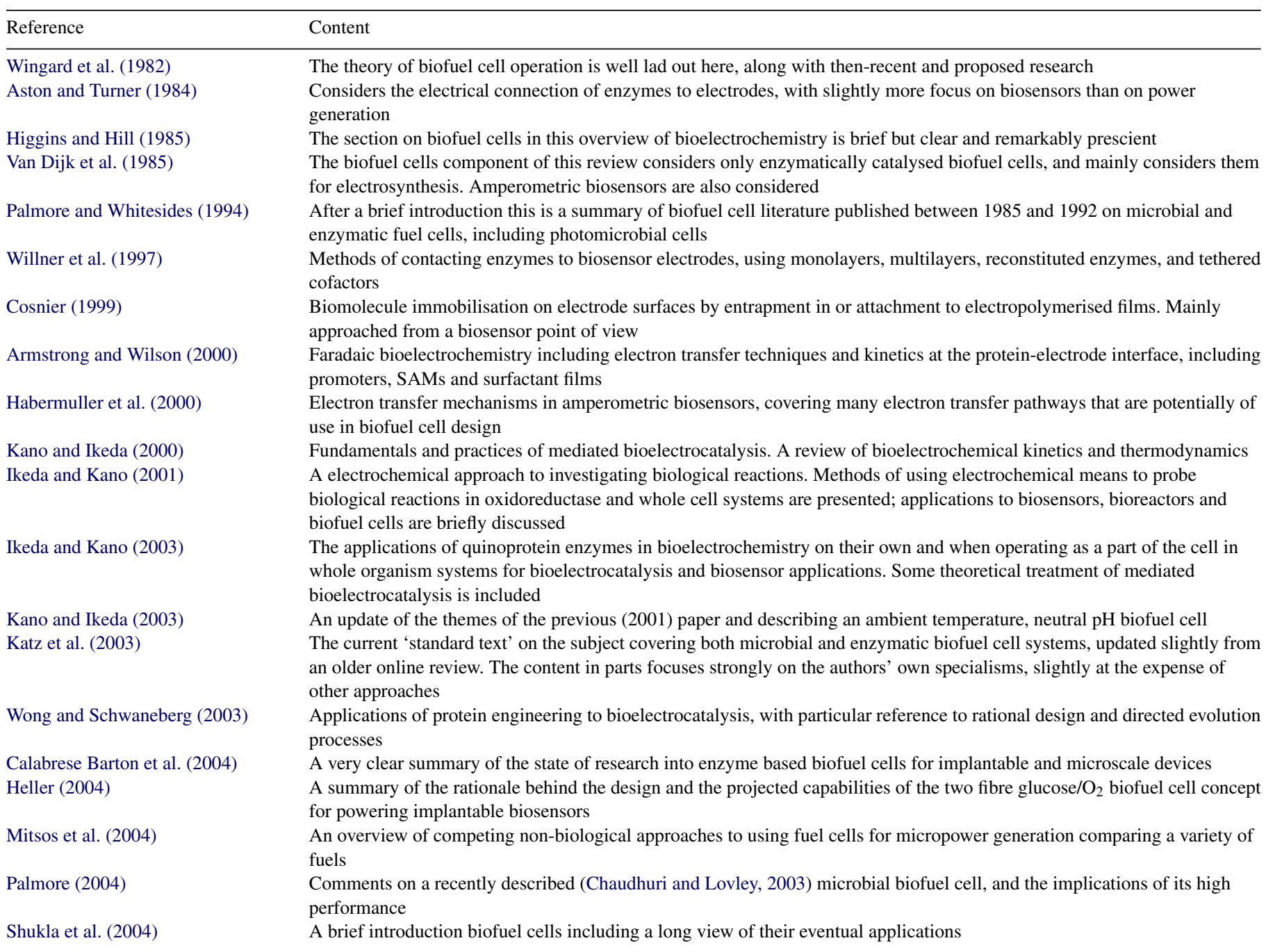


or even permanent power supply for such devices as pacemakers, glucose sensors for diabetics or small valves for bladder control. The early goal of powering an artificial heart has been abandoned as the difficulty of realising a functioning implant has become more apparent. Once small systems are in place and functioning, this challenge may well be revisited. A biofuel cell capable of operation implanted in a grape (Mano et al., 2003a) shows that progress is being made in this. The challenge of biocatalysis over a suitably long period is particularly problematic in these areas, where surgical intervention could be required to change over to a new cell and ethical constraints are paramount.

Ex vivo proposed applications are diverse. The large scale is represented by proposed power recovery from waste streams with simultaneous remediation by bioelectrochemical means, or purely for power generation in remote areas, the medium scale by power generating systems for specialist applications such as the gastrobot above, and perhaps of greatest potential the small scale power generation to replace battery packs for consumer electronic goods such as laptop computers or mobile telephones. The larger scale applications tend to be organism based and the smaller scale ones more likely to be enzymatic. In the case of enzymatic fuel cells, at least, the major barrier to any successful application is component lifetime, particularly in view of the limited enzyme lifetime and problems of electrode fouling/poisoning.

\subsection{Key performance characteristics}

For any fuel cell the power output, $P_{\text {cell }}$ is likely to be the bottom line determining its value.

$P_{\text {cell }}=E_{\text {cell }} \int I \mathrm{~d} t$

Or, if the current is constant $P_{\text {cell }}=E_{\text {cell }} I$.

The overall cell voltage that can be derived from any electrochemical system is given by:

$E_{\text {cell }}=E_{\mathrm{C}}-E_{\mathrm{A}}-\sum I R_{\mathrm{e}}$

$E_{\mathrm{C}}$ and $E_{\mathrm{A}}$ are experimental potentials of the cathode and anode, respectively. These electrode potentials can be related to the equilibrium potential for the couple by:

$\eta=E-E_{\mathrm{e}}$

The equilibrium potential is in turn related to the formal potential $E_{\mathrm{e}}^{0}$ for the couple (the potential when the reduction and oxidation potentials are equal) by:

$E_{\mathrm{e}}=E_{\mathrm{e}}^{0}+\frac{R T}{z F} \ln \left(\frac{c_{\mathrm{O}}}{c_{\mathrm{R}}}\right)$

To obtain an optimal voltage from a cell it is desirable to maximise the driving force $\left(E_{\mathrm{C}}-E_{\mathrm{A}}\right)$ and to minimise the ohmic resistance losses, $\sum I R$. The latter can be achieved through appropriate cell design considerations such as minimising the inter-electrode gap or operating at low current density. Low current density operation is, however, counter to the generation of a high power density.
For a fuel cell to be viable, its total energy budget (power output from the cell minus power consumed by pumping, stirring, sparging and any other 'utilities') must be positive. The utility costs must be minimised by appropriate chemical or physical design or economies of scale, or may be eliminated altogether in some situations (a conventional battery has no pumping costs, relying purely on diffusion, an implanted biofuel cell in vivo could rely on the heart to perform the pumping duty, etc.).

As one of the target applications for biofuel cells is portable power (particularly for enzymatic cells) consideration must be given to the size of a proposed device. For the fuel cell itself

Power density $=\frac{P_{\text {cell }}}{A}$

and

Volumetric power $=\frac{P_{\text {cell }}}{V_{\mathrm{e}}}=\frac{A_{\mathrm{e}}}{A} P_{\text {cell }}$

For a complete fuel cell system it is also necessary to consider the fuel as adding volume and, for man-portable systems especially, weight. Another useful metric to consider is:

Specific power $=\frac{P_{\text {cell }}}{\sum m_{\text {cell,fuel(s), utilities }}}$

\subsection{Definitions and classifications of biofuel cells}

It is important to review the fundamental definitions relevant to biofuel cells. A generalised schematic of a biofuel cell half cell is presented in Fig. 1, and an overview of different types of power generating electrochemical devices is presented in Fig. 2. This overview allows us to consider the different definitions that a device has to conform to in order to be a biofuel cell, and allows the characterisation of different biofuel cell-like devices.

Electrochemical devices convert energy directly from a chemical to an electrical form. This allows them to bypass the thermodynamic limitations of combustion based power cycles. Furthermore, in an electrochemical system, the rate of energy production can be finely controlled through an external circuit.

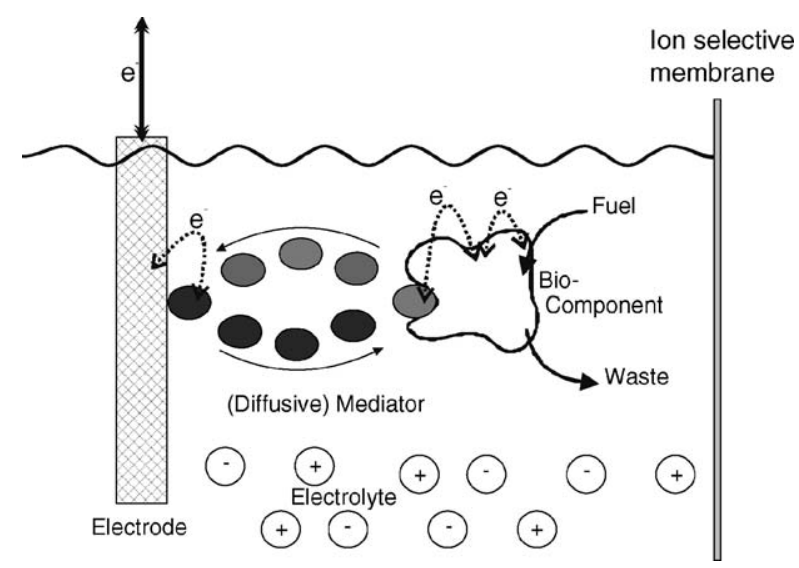

Fig. 1. Schematic of a generalised half-biofuel cell. A fuel is oxidised (or oxidant reduced) at a biological component (enzyme or organism), and electrons are transferred to (or from) a mediator, which either diffuses to or is associated with the electrode and is oxidised (reduced) to its original state. 




Fig. 2. A classification of biofuel cells.

\subsubsection{Classification of electrochemical devices according to fuel containment}

A battery is an electrochemical device that allows a reaction to occur at an anode and a cathode, the fuel being contained internally by the battery housing (Gileadi, 1993).

A fuel cell is a similar device in which fuel is supplied from outside the housing and wastes resulting from a spent fuel are removed. It is not a requirement that the fuel is added continuously, merely that it is stored and supplied from outside the reaction chambers (Gileadi, 1993).
Bridging the gap between batteries and fuel cells are hybrid devices and redox flow cells. Hybrid devices such as metal-air cells are batteries in the anode compartment, oxidising metals to their ions in solution while being fuel-cell-like in the cathode compartment with air from the atmosphere supplying oxygen to be reduced to form hydroxyl ions (Haas et al., 2003; Vielstich et al., 2003). Redox flow cells are composed of an electrochemical cell with large volumes of liquid fuel stored locally but externally in a closed loop. Power can be supplied to the cell to drive a charging set of reactions. The energy can be stored in chemical form until the cell is discharged to 
generate current. As the charged chemical is stored outside the main body of the electrochemical cell this can be considered as resembling a fuel cell but it cannot truly be fuelled indefinitely (Divisek and Emonts, 2003).

\subsubsection{Fuel and catalysis sources}

Any type of electrochemical device will require both a fuel and a catalyst, and by considering these, further definitions can be arrived at:

Inorganic devices utilise inorganic chemistries and usually employ metals as catalysts (Palmore and Whitesides, 1994), for example the classic Pt-catalysed $\mathrm{H}_{2} / \mathrm{O}_{2}$ fuel cell $\left(E_{\text {cell }}^{0}=\right.$ $1.23 \mathrm{~V})$,

$\mathrm{H}_{2} \stackrel{\mathrm{Pt} / \text { anode }}{\longrightarrow} 2 \mathrm{H}^{+}+4 \mathrm{e}^{-}$

$\frac{1}{2} \mathrm{O}_{2}+2 \mathrm{H}^{+}+4 \mathrm{e}^{-\stackrel{\mathrm{Pt} / \text { cathode }}{\longrightarrow}} \mathrm{H}_{2} \mathrm{O}$

or an Al/Air hybrid battery.

Organically fuelled devices operate using more complex chemicals as fuel sources, but still rely on inorganic catalysts to achieve the reactions as in, for example, the direct methanol fuel cell (DMFC) $\left(E_{\text {cell }}^{0}=1.20 \mathrm{~V}\right)$.

$\mathrm{CH}_{3} \mathrm{OH}+\mathrm{H}_{2} \mathrm{O} \stackrel{\text { inorganic_anode }}{\longrightarrow} \mathrm{CO}_{2}+6 \mathrm{H}^{+}+6 \mathrm{e}^{-}$

$\frac{3}{2} \mathrm{O}_{2}+6 \mathrm{H}^{+}+6 \mathrm{e}^{\stackrel{\text { inorganic_cathode }}{\longrightarrow}} 3 \mathrm{H}_{2} \mathrm{O}$

Biologically catalysed devices (usually also organically fuelled) utilise biological molecules as catalysts for achieving their redox reactions (in at least one half cell), either as purified enzymes (or enzyme derivatives) to catalyse a specific reaction, or through the use of whole organisms (Palmore and Whitesides, 1994). For methanol oxidation (11) a nicotinamide adenine dinucleotide (NAD) mediated sequence of reactions is (Palmore et al., 1998):

$$
\begin{aligned}
& \mathrm{CH}_{3} \mathrm{OH}+2 \mathrm{NAD}^{+} \stackrel{\text { alcohol_dehydrogenase }}{\longrightarrow} \mathrm{CH}_{2} \mathrm{O}+2 \mathrm{NADH} \\
& \mathrm{CH}_{2} \mathrm{O}+\mathrm{H}_{2} \mathrm{O}+2 \mathrm{NAD}^{+} \stackrel{\text { aldehyde_dehydrogenase }}{\longrightarrow} \mathrm{HCOOH} \\
& +2 \mathrm{NADH}
\end{aligned}
$$

$$
\begin{aligned}
& \mathrm{HCOOH}+2 \mathrm{NAD}^{+} \stackrel{\text { formate_dehydrogenase }}{\longrightarrow} \mathrm{CO}_{2}+2 \mathrm{NADH} \\
& 3 \mathrm{NADH}+6 \mathrm{Mediator}_{\text {red }} \stackrel{\text { diaphorase }}{\longrightarrow} 3 \mathrm{NAD}^{+}+6 \text { Mediator }_{\mathrm{Ox}} \\
& 6 \mathrm{Mediator}_{\mathrm{ox}} \stackrel{\text { anode }}{\longrightarrow} 6 \text { Mediator }_{\mathrm{red}}+6 \mathrm{e}^{-}
\end{aligned}
$$

In practice, working cell voltages tend to be $\ll 0.5 \mathrm{~V}$ due to kinetic restrictions.

This latter category combined with the various types of electrochemical device allows for the definition of the biological battery (biobattery) and biological fuel cell (biofuel cell). A bio-redox flow cell has not yet been demonstrated, nor has any suitable chemistry for such a device been proposed.

\subsubsection{Origin of enzymes for biologically catalysed devices}

Biologically catalysed devices can be divided according to the source of the biocatalysts (usually enzymes) used to perform the catalysis.
Microbially catalysed systems use whole living organisms as the source of complete enzyme pathways. These are generally robust systems that can operate on variable feedstocks and are resistant to poisoning due to being living systems, and are usually capable of oxidising the substrate completely to carbon dioxide and water. For example direct electrochemical communication of Shewanella putrefaciens with an anode via membrane cytochromes (Kim et al., 2002a).

Lactate $\stackrel{\text { microbial_metabolism }}{\longrightarrow}$ wastes $+(\text { membrane_cytochrome })^{-}$

(membrane_cytochrome $) \stackrel{\text { anode }}{\longrightarrow}($ membrane_cytochrome $)+\mathrm{e}^{-}$

Enzymatically catalysed systems use isolated and purified enzyme proteins to perform specific reaction catalysis (reactions (13)-(17)). This generally gives a better defined system and several enzymes can be combined to completely oxidise the substrate, although structuring the enzymes so that the different reactions can occur in the right order is problematic. In some cases protein units smaller than complete enzymes can be used as catalysts, but these cases can be treated as enzymes for fuel cell purposes.

\subsubsection{Method of electron transfer between reaction site and electrode}

Electrons can transfer between the reaction site and the electrode through the diffusion of a secondary fuel, via a mediator molecule that repeatedly cycles or via a direct electron transfer (DET) between the reaction site and the electrode.

There has been some variation in the literature on how to define these types of systems. Aston and Turner (1984) define a system in which a secondary fuel for the electrode is generated by the biological reaction as indirect biofuel cells, with cases involving electron-shuttling reversible mediators or direct electron transfer between the biological component and the electrode being direct biofuel cells. However Palmore and Whitesides (1994) define indirect biofuel cells as any that include a diffusive component, hence according to their definition a system involving diffusing reversible mediators is indirect, but one involving non-diffusing mediators is direct. Higgins and Hill (1985) defined three categories; product type (organisms or enzymes convert electrochemically inactive species to electrochemically active species), regenerative type (organisms or enzymes regenerate redox compounds which in turn carry out the electrochemical reaction) or depolariser type (organisms or enzymes act as catalysts of the electrochemical reactions at the electrode, or themselves diffuse to the electrode and transfer electrons directly). These definitions, while internally consistent and comprehensive are unsatisfactory, particularly the use of the word 'depolariser' which is misleading in the context of electrochemistry.

Enzymatic cells have been divided into mediated electron transfer (MET) and direct electron transfer (DET), with DET covering only systems where the electron tunnels directly from the active site fixed in the enzyme to the electrode, and MET 
encompassing all forms of regenerative mediation whether diffusive or non-diffusive (Calabrese Barton et al., 2004). Product type operation was not covered.

This paper will also consider DET in the case using whole microorganisms where electrons transfer directly between the surface of a microorganism and an electrode. MET will similarly be used to describe microbiological fuel cells where a mediator molecule is used as an electron relay.

\section{Bioelectrochemical cells involving a whole organism}

The use of whole organisms as a biofuel cell system allow multiple enzymes and hence multiple substrates (or mixed substrates) to be used, with the organisms contained in the fuel cell system acting as micro-reactors providing appropriate conditions for each enzyme to act optimally. Recent examples of biofuel cells making use of whole organisms as catalysts are tabulated in Table 3.

Evolution has produced highly efficient electron control systems within living organisms. This informs a search for a mediating system that can either transport readily across the cell membrane in both directions, exchanging electrons with the metabolic system inside the cell and the electrode outside it, or that can contact the membrane and collect electrons without penetrating the cell. The former approach tends to lead to indirect electron transfer systems with freely diffusing mediator molecules (diffusive MET), and the latter to indirect transfer systems with the mediator incorporated into the electrode or the cell membrane (non-diffusive MET). In MET cases, it is desirable for a mediator to have a reaction potential as close to that of the biological component to minimise potential losses. (The overall cell potential is determined by the terminal electron transfer to or from the electrode.)

In some organisms, DET can be achieved through the existence of electron transferring capacity within the cell membrane (Kim et al., 1999; Kim et al., 2002a), occurring either naturally or through genetic engineering.

The third mode of operation, product type, relies on the microbial metabolism releasing a secondary fuel product that then diffuses to the electrode and is oxidised or reduced (as appropriate) to form a final waste product, which is discharged. In practice, product operation has many similarities to conventional fermentation processes, with the fermentation product being the fuel used at the electrode. Indeed, product systems could be separated into two entirely separate processes with the products of the microbial reaction being stored and fed to a fuel cell process as the fuel. Such systems are not biofuel cell systems, but the distinction is not as certain when the vessels are directly connected.

\subsection{Whole organism product biofuel cells}

Product systems producing hydrogen gas were recently reviewed by Das and Veziroglu (2001). In general they are nonelectrochemical processes, consisting of the photosynthetic or fermentative generation of hydrogen in a vessel entirely separate from that containing the electrolytic fuel cell system. Maness and Weaver achieved the water-gas shift reaction (20) producing $\mathrm{H}_{2}$ and $\mathrm{CO}_{2}$ from $\mathrm{CO}$ and $\mathrm{H}_{2} \mathrm{O}$ using photosynthetic bacteria Rhodocyclus gelatinosus and Rhodospirillum rubrum.

$\mathrm{CO}+\mathrm{H}_{2} \mathrm{O} \stackrel{\text { bacteria }}{\longleftrightarrow} \mathrm{H}_{2}+\mathrm{CO}_{2}$

In particular they were able to use bacterial strains that would incorporate $\mathrm{CO}$ into their cell mass, leaving almost pure hydrogen ( $0.1 \mathrm{ppm} \mathrm{CO}$ at equilibrium) which could be fed directly to an (inorganic) fuel cell (Maness and Weaver, 1994) and isolate an oxygen tolerant, CO-linked terminal hydrogenase enzyme (Maness and Weaver, 1999) which may lead to the genetic engineering of a cyanobacterium capable of producing hydrogen from water in photosynthetic conditions (Fig. 3A).

Other fuels can also be produced by product processes; by definition biofuels are obtained from the manipulation of organic processes. Microbial product processes to generate a fuel from waste products have been developed such as methane mass production from food wastes (Kim et al., 2002b). These systems are essentially not biofuel cells, although the overall process when such a system is connected to an appropriate fuel cell system

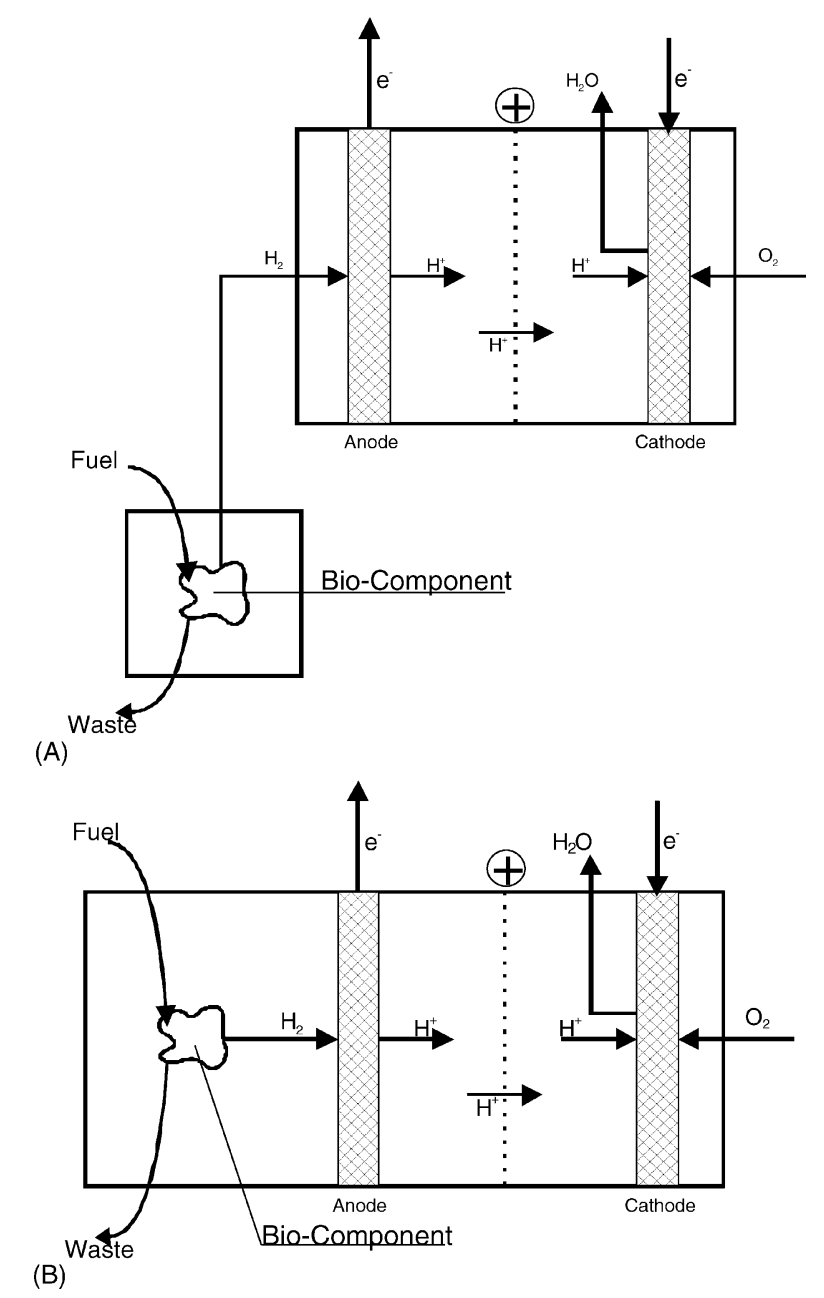

Fig. 3. Schematic illustrating product type systems. (A) External fermenter feeding hydrogen to $\mathrm{H}_{2} / \mathrm{O}_{2}$ inorganic fuel cell (after Maness and Weaver, 1994). (B) Single compartment fermenter/electrode biofuel cell anode (after Niessen et al., 2004). 
Summary of microbial bioelectrochemical devices

\begin{tabular}{|c|c|c|c|c|c|c|c|c|}
\hline $\begin{array}{l}\text { System } \\
\text { (oxidation/reduction) }\end{array}$ & Organism & Electrodes $\left(\right.$ area $\left./ \mathrm{cm}^{2}\right)$ & Electrolyte & $\mathrm{OCV}(\mathrm{V})$ & $\begin{array}{l}\text { Current } \\
\text { density } \\
\left(\mu \mathrm{Acm}^{-2}\right)\end{array}$ & $\begin{array}{l}\text { Power density } \\
\left(\mu \mathrm{Acm}^{-2}\right)\end{array}$ & Comments & Reference \\
\hline \multicolumn{9}{|c|}{ (A) Fueled primarily by glucose oxidation } \\
\hline $\begin{array}{l}\text { MET } \\
\text { glucose/ferricyanide } \\
\text { (at RVC cathode) or } \\
\mathrm{O}_{2} \text { (at PCP cathode) }\end{array}$ & $\begin{array}{l}\text { Proteus vulgaris } \\
\text { immobilised on anode } \\
\text { surface by an amide link, } \\
\text { anaerobic }\end{array}$ & $\begin{array}{l}1 \mathrm{~g} \text { graphite felt anode } \\
(49.5), \text { RVC (not given) } \\
\text { or PCP cathode (20.25) }\end{array}$ & $\begin{array}{l}\text { HNQ diffusing mediator, } \\
50 \mathrm{mmol} \mathrm{dm}^{-3}, \mathrm{pH} 7.0 \\
\text { potassium phosphate } \\
\text { buffer at anode. } \\
50 \mathrm{mmol} \mathrm{dm}^{-3} \text { potassium } \\
\text { ferricyanide in buffer or } \\
500 \mathrm{mmol} \mathrm{dm}^{-3} \\
\text { phosphate buffer at } \\
\text { cathode }\end{array}$ & $\begin{array}{l}0.7 \text { with air } \\
\text { cathode }\end{array}$ & 8.1 & 3.2 & $\begin{array}{l}\text { Controlled by glucose } \\
\text { addition when cell } \\
\text { voltage dropped below } \\
0.4 \mathrm{~V} \text {, maintained for } 5 \\
\text { days. Stable coulombic } \\
\text { efficiency } 25 \%\end{array}$ & $\begin{array}{l}\text { Allen and } \\
\text { Bennetto (1993) }\end{array}$ \\
\hline $\begin{array}{l}\text { MET (various) } \\
\text { sugar/ferricyanide }\end{array}$ & $\begin{array}{l}\text { Suspended Proteus } \\
\text { vulgaris, anaerobic }\end{array}$ & $\begin{array}{l}\text { RVC anode (30.4), } \\
\text { platinum cathode (16) }\end{array}$ & $\begin{array}{l}37^{\circ} \mathrm{C} \text {, thionin diffusing } \\
\text { mediator, } \mathrm{pH} 7.0\end{array}$ & N/A & 13.8 & 5.8 & $\begin{array}{l}1 \mathrm{k} \Omega \text { external load. } \\
\text { Maximum coulombic } \\
\text { efficiency } 56 \% \text { oxidising } \\
\text { glucose after culture on } \\
\text { galactose }\end{array}$ & $\begin{array}{l}\text { Kim et al. } \\
(2000 b)\end{array}$ \\
\hline $\begin{array}{l}\text { MET (various) } \\
\text { sugar/ferricyanide }\end{array}$ & $\begin{array}{l}\text { Suspended Proteus } \\
\text { vulgaris, anaerobic }\end{array}$ & $\begin{array}{l}\text { RVC anode (30.4), } \\
\text { platinum cathode (16) }\end{array}$ & $\begin{array}{l}\text { Thionin diffusing } \\
\text { mediator, phosphate } \\
\text { buffer, } \mathrm{pH} 7.0 \text {. } \\
0.1 \mathrm{~mol} \mathrm{dm}^{-3} \text { ferricyanide } \\
\text { in catholyte }\end{array}$ & $\begin{array}{l}0.52 \text { (with } \\
1 \mu \mathrm{A})\end{array}$ & 13.2 & 5.26 & $\begin{array}{l}\text { Maximum efficiency at } \\
37^{\circ} \mathrm{C} \text {. OCV, current and } \\
\text { power densities extracted } \\
\text { from figures }\end{array}$ & $\begin{array}{l}\text { Kim et al. } \\
\text { (2000a) }\end{array}$ \\
\hline $\begin{array}{l}\text { MET } \\
\text { glucose/ferricyanide }\end{array}$ & $\begin{array}{l}\text { Suspended } E \text {. coli or } A \text {. } \\
\text { succinogenes or mixed } \\
\text { culture sewage sludge, } \\
\text { anaerobic }\end{array}$ & $\begin{array}{l}12 \mathrm{~g} \text { woven graphite felt } \\
\text { anode, } 12 \mathrm{~g} \text { woven } \\
\text { graphite felt cathode. } \\
47 \mathrm{~cm}^{2} \mathrm{~g} \text { (superficial area } \\
\text { unknown) }\end{array}$ & $\begin{array}{l}\text { Organism, glucose, } \\
100 \mu \mathrm{mol} \mathrm{dm} \mathrm{dm}^{-3} \mathrm{NR} \text { or } \\
300 \mu \mathrm{mol} \mathrm{dm}-3 \text { thionin } \\
\text { mediator, } 50 \mathrm{mmol} \mathrm{dm}^{-3} \\
\text { phosphate buffer } \mathrm{pH} 7.0 \\
\text { at anode. } 100 \mathrm{mmol} \mathrm{dm}^{-3} \\
\text { phosphate buffer } \mathrm{pH} 7.0 \\
\text { containing } 50 \mathrm{mmol} \mathrm{dm}^{-3} \\
\text { ferricyanide at cathode }\end{array}$ & 0.85 & 8.5 & 5.3 & $\begin{array}{l}\text { Current and power } \\
\text { densities on the basis of } \\
\text { non-superficial area }\end{array}$ & $\begin{array}{l}\text { Park and Zeikus } \\
(2000)\end{array}$ \\
\hline $\begin{array}{l}\text { DET } \\
\text { glucose/ferricyanide }\end{array}$ & $\begin{array}{l}\text { Rhodoferax ferrireducens, } \\
\text { anaerobic }\end{array}$ & $\begin{array}{l}\text { Graphite rod }(0.65) \text {, foam } \\
\text { (0.61) or felt }(2.0) \\
\text { electrodes }\end{array}$ & $\begin{array}{l}80: 20 \mathrm{~N}_{2} / \mathrm{CO}_{2} \text { flushed, } \\
10 \mathrm{mmol} \mathrm{dm} \mathrm{dm}^{-3} \text { glucose } \\
\text { solution at anode (more } \\
\text { information N/A), } \\
\text { water-saturated air flushed } \\
30 \mathrm{mmol} \mathrm{dm}{ }^{-3} \text { Tris buffer } \\
\text { pH } 7.0 \text { cathode with } \\
\text { potassium ferricyanide }\end{array}$ & N/A & $\begin{array}{l}3.1 \text { with } \\
1000 \Omega \\
\text { external load }\end{array}$ & N/A & $\begin{array}{l}81 \% \text { coulombic efficiency } \\
\text { observed for glucose } \\
\text { oxidation. Current } \\
\text { production not affected by } \\
\text { medium replacement } \\
\text { (DET by } \\
\text { anode-associated cells } \\
\text { implied) }\end{array}$ & $\begin{array}{l}\text { Chaudhuri and } \\
\text { Lovley (2003) }\end{array}$ \\
\hline MET glucose $/ \mathrm{O}_{2}$ & $\begin{array}{l}\text { Suspended } E . \text { coli } \text { or } \\
\text { sewage sludge, anaerobic }\end{array}$ & $\begin{array}{l}\text { Woven graphite }\left(^{*}\right) \text {, } \\
\text { NR-woven graphite }(80) \\
\text { or } \mathrm{Mn}^{4+} \text {-graphite plate } \\
\text { anode }(80), \text { woven } \\
\text { graphite }\left(^{*}\right) \text { or } \\
\mathrm{Fe}^{3+} \text {-graphite plate }(80) \\
\text { cathode }\end{array}$ & $\begin{array}{l}100 \mathrm{mmol} \mathrm{dm}^{-3} \\
\text { phosphate buffer, } \\
10 \mathrm{~g} \mathrm{dm}^{-3} \text { sodium lactate, } \\
5 \mathrm{~g} \mathrm{dm}^{-3} \text { peptone, and } \\
5 \mathrm{~g} \mathrm{dm}^{-3} \text { yeast extract. } \\
\text { pH } 7.0\end{array}$ & N/A & $\begin{array}{l}109(\mathrm{NR}- \\
\text { woven/Fe } \\
175 \\
\left(\mathrm{Mn}^{4+} / \mathrm{Fe}^{3+}\right)\end{array}$ & $\begin{array}{l}84.5(\mathrm{NR}- \\
\left.\text { woven } / \mathrm{Fe}^{3+}\right), \\
78.8 \\
\left(\mathrm{Mn}^{4+} / \mathrm{Fe}^{3+}\right)\end{array}$ & $\begin{array}{l}\text { Single compartment } \\
\text { design. Best current and } \\
\text { power densities obtained } \\
\text { with sewage sludge. } \\
\text { *Woven graphite anodes } \\
\text { are } 1.27 \mathrm{~m}^{2} \\
\text { non-superficial area }\end{array}$ & $\begin{array}{l}\text { Park and Zeikus } \\
\text { (2003) }\end{array}$ \\
\hline
\end{tabular}




\begin{tabular}{|c|c|c|c|c|c|c|c|c|}
\hline $\begin{array}{l}\text { MET and DET } \\
\text { glucose/oxygen }\end{array}$ & $\begin{array}{l}\text { Mixed culture derived } \\
\text { from anaerobic } \\
\text { methanogenic sludge, } \\
\text { some experiments with } \\
\text { purified isolates, } \\
\text { anaerobic }\end{array}$ & $\begin{array}{l}\text { Graphite plate electrodes } \\
(50)\end{array}$ & $\begin{array}{l}\text { 'Oxoid' nutrient broth at } \\
\text { anode } \\
0.5-5 \mathrm{~g} \mathrm{dm}^{-3} \text { day }^{-1} \\
\text { glucose, nitrogen purged, } \\
100 \mathrm{mmol} \mathrm{dm}{ }^{-3} \\
\text { phosphate buffer, } \\
100 \mathrm{mmol} \mathrm{dm}^{-3} \\
\text { potassium } \\
\text { hexacyanoferrate, } \\
\text { continuous aeration at } \\
\text { cathode }\end{array}$ & N/A & N/A & 360 & $\begin{array}{l}\text { Four cells to a block, } \\
\text { two blocks operated } \\
\text { in parallel }\end{array}$ & $\begin{array}{l}\text { Rabaey et al. } \\
(2003)\end{array}$ \\
\hline $\begin{array}{l}\text { DET } \\
\text { glucose/ferricyanide }\end{array}$ & $\begin{array}{l}\text { Suspended E. coli, } \\
\text { anaerobic }\end{array}$ & $\begin{array}{l}\text { Woven graphite cloth } \\
\text { (7.5) platinised and } \\
\text { polyaniline modified as } \\
\text { anode, unmodified woven } \\
\text { graphite cloth cathode } \\
\text { (7.5) }\end{array}$ & $\begin{array}{l}10 \mathrm{~g} \mathrm{dm}^{-3} \text { glucose, } \\
5 \mathrm{~g} \mathrm{dm}^{-3} \text { yeast extract, } \\
10 \mathrm{~g} \mathrm{dm}^{-3} \mathrm{NaHCO}_{3} \text { and } \\
8.5 \mathrm{~g} \mathrm{dm}^{-3} \mathrm{NaH}_{2} \mathrm{PO}_{4} \text { at } \\
\text { anode, } 50 \mathrm{mmol} \mathrm{dm}^{-3} \\
\text { ferricyanide solution, } \\
10 \mathrm{~g} \mathrm{dm}^{-3} \mathrm{NaHCO}_{3} \text { and } \\
8.5 \mathrm{~g} \mathrm{dm}^{-3} \mathrm{NaH}_{2} \mathrm{PO}_{4} \text { at } \\
\text { cathode }\end{array}$ & 0.895 & 2600 & 1200 & $\begin{array}{l}5 \mathrm{~s} \text { oxidative pulses } \\
\text { every } 1000 \mathrm{~s} \text { can be } \\
\text { used to regenerate the } \\
\text { anode. Current and } \\
\text { power are 'steady } \\
\text { state' values but the } \\
\text { stabilisation time is } \\
\text { not defined }\end{array}$ & $\begin{array}{l}\text { Schroder et al. } \\
\text { (2003) }\end{array}$ \\
\hline $\begin{array}{l}\text { Product biofuel cell } \\
\text { using starch, glucose } \\
\text { or molasses to } \\
\text { generate } \\
\mathrm{H}_{2} / \text { ferricyanide }\end{array}$ & $\begin{array}{l}\text { Clostridium butyricum or } \\
\text { Clostridium beijerinckii }\end{array}$ & $\begin{array}{l}\text { Woven graphite cloth } \\
\text { (7.5) platinised and } \\
\text { poly(tetrafluoroaniline) } \\
\text { modified as anode, } \\
\text { unmodified woven } \\
\text { graphite cathode ( } 7.5)\end{array}$ & $\begin{array}{l}10 \mathrm{~g} \mathrm{dm}^{-3} \text { substrate, } \\
5 \mathrm{~g} \mathrm{dm}^{-3} \text { yeast extract, } \\
10 \mathrm{~g} \mathrm{dm}^{-3} \text { peptone, } \\
0.5 \mathrm{~g} \mathrm{dm}^{-3} \\
\mathrm{~L} \text {-cysteine- } \mathrm{HCl} \text {, } \\
8 \mathrm{mg} \mathrm{dm}^{-3} \mathrm{CaCl}_{2} \text {, } \\
8 \mathrm{mg} \mathrm{dm}^{-3} \mathrm{MgSO}_{4} \text {, } \\
40 \mathrm{mg} \mathrm{dm}^{-3} \mathrm{KHSO}_{4} \text {, } \\
80 \mathrm{mg} \mathrm{dm}^{-3} \mathrm{NaCl} \\
0.4 \mathrm{~g} \mathrm{dm}^{-3} \mathrm{NaHCO}_{3} \text { and } \\
1 \mathrm{mg} \mathrm{dm}^{-3} \text { resazurine, } \\
\text { nitrogen purged at anode. } \\
50 \text { mmol dm}^{-3} \\
\text { ferricyanide solution in } \\
\text { phosphate buffer pH } 7.0 \\
\text { at cathode }\end{array}$ & 0.759 & $\begin{array}{l}5070 \text { (steady } \\
\text { state) or } \\
16,000 \text { (peak } \\
\text { value) }\end{array}$ & $\begin{array}{l}4000 \text { (at } \\
0.473 \mathrm{~V} \text { ) }\end{array}$ & $\begin{array}{l}\text { Steady state } \\
\text { stabilisation time not } \\
\text { defined }\end{array}$ & $\begin{array}{l}\text { Niessen et al. } \\
(2004)\end{array}$ \\
\hline $\begin{array}{l}\text { MET and DET } \\
\text { glucose/ferricyanide }\end{array}$ & $\begin{array}{l}\text { Mixed culture from } \\
\text { anaerobic methanogenic } \\
\text { sludge, some experiments } \\
\text { with purified isolates, } \\
\text { anaerobic }\end{array}$ & $\begin{array}{l}\text { Graphite plate electrodes } \\
\text { (50) }\end{array}$ & $\begin{array}{l}\text { Anolyte 'nutrient broth' } \\
\text { with glucose fed at } \\
1 \mathrm{~g} \mathrm{dm}^{-3} \mathrm{day}^{-1} \text {. } \\
\text { Catholyte } 50 \mathrm{mmol} \mathrm{dm}^{-3} \\
\text { potassium ferricyanide } \\
\text { solution in } \\
100 \mathrm{mmol} \mathrm{dm}^{-3} \text { potassium/ } \\
\text { phosphate buffer pH } 7.0\end{array}$ & sodium & N/A & $\begin{array}{l}431 \\
\text { (maximum, at } \\
0.66 \mathrm{~V})\end{array}$ & $\begin{array}{l}\text { A long-term study } \\
\text { over several months, } \\
\text { with many } \\
\text { investigations into the } \\
\text { bacterial and } \\
\text { electrochemical cell } \\
\text { behaviour }\end{array}$ & $\begin{array}{l}\text { Rabaey et al. } \\
\text { (2004) }\end{array}$ \\
\hline \multicolumn{9}{|c|}{ B) Primarily using other fuels } \\
\hline $\begin{array}{l}\text { MET lactate and } \\
\text { pyruvate/- }\end{array}$ & $\begin{array}{l}\text { Desulphovibrio } \\
\text { desulphuricans, anaerobic }\end{array}$ & Activated charcoal anode & $\begin{array}{l}\text { Sulphate/sulphide } \\
\text { mediator, } \mathrm{pH} 7.8\end{array}$ & N/A & 1980 & N/A & $\begin{array}{l}\text { Lactate gives a higher } \\
\text { specific current } \\
\text { density but pyruvate } \\
\text { used } 40 \% \text { less } \\
\text { sulphate }\end{array}$ & $\begin{array}{l}\text { Cooney et al. } \\
\text { (1996) }\end{array}$ \\
\hline
\end{tabular}




\begin{tabular}{|c|c|c|c|c|c|c|c|c|}
\hline $\begin{array}{l}\text { System } \\
\text { (oxidation/reduction) }\end{array}$ & Organism & Electrodes $\left(\right.$ area $\left./ \mathrm{cm}^{2}\right)$ & Electrolyte & OCV (V) & $\begin{array}{l}\text { Current } \\
\text { density } \\
\left(\mu \mathrm{Acm}^{-2}\right)\end{array}$ & $\begin{array}{l}\text { Power density } \\
\left(\mu \mathrm{Acm}^{-2}\right)\end{array}$ & Comments & Reference \\
\hline $\begin{array}{l}\text { DET lactate (also } \\
\text { pyruvate and for- } \\
\text { mate)/ferricyanide }\end{array}$ & $\begin{array}{l}\text { Suspended Shewanella } \\
\text { putrefaciens, anaerobic }\end{array}$ & $\begin{array}{l}\text { Carbon felt anode (9.3), } \\
\text { RVC cathode (21.6) }\end{array}$ & $\begin{array}{l}0.05 \mathrm{~mol} \mathrm{dm}^{-3} \text { phosphate } \\
\text { buffer containing } \\
0.1 \mathrm{~mol} \mathrm{dm} \mathrm{dm}^{-3} \mathrm{NaCl}, \mathrm{pH} \\
\text { 7.0. Anode also contains } \\
\text { FeOOH }\end{array}$ & N/A & 0.645 & N/A & $\begin{array}{l}500 \Omega \text { external resistance. } \\
\text { Biosensor, rate of current } \\
\text { increase approximately } \\
\text { proportional to lactate } \\
\text { concentration }\end{array}$ & Kim et al. (1999) \\
\hline MET acetate $/ \mathrm{O}_{2}$ & $\begin{array}{l}\text { Suspended E. coli, } \\
\text { anaerobic }\end{array}$ & $\begin{array}{l}\text { NR-modified graphite } \\
\text { plate anode (118), } \\
\text { graphite plate cathode } \\
\text { (118) }\end{array}$ & $\begin{array}{l}80 \mathrm{mmol} \mathrm{dm}^{-3} \text { acetate, } \\
1 \mathrm{~g} \mathrm{dm}^{-3} \text { of each of } \\
\mathrm{KH}_{2} \mathrm{PO}_{4}, \text { yeast extract, } \\
\text { peptone, } \mathrm{NH}_{4} \mathrm{Cl} \text { and } \\
\mathrm{CaCl}_{2}, 2 \mathrm{~g} \mathrm{dm}^{-3} \mathrm{NaCl} \text { at } \\
\text { anode. } 1 \mathrm{~mol} \mathrm{dm}^{-3} \mathrm{KCl} \text { at } \\
\text { cathode }\end{array}$ & N/A & 3.1 & 1.14 & $\begin{array}{l}\text { Current and power } \\
\text { densities with native (i.e. } \\
\text { no NR) anode were } \\
1.41 \mu \mathrm{A} \mathrm{cm}^{-1} \text { and } \\
0.239 \mu \mathrm{W} \mathrm{cm}^{-2} \text {, } \\
\text { respectively }\end{array}$ & Park et al. (2000) \\
\hline MET $\mathrm{H}_{2} / \mathrm{MET} \mathrm{O}_{2}$ & $\begin{array}{l}\text { Suspended } \\
\text { Desulphovibrio vulgaris, } \\
\text { hydrogen saturated } \\
\text { (anode) } / 0.1 \mu \mathrm{mol} \mathrm{dm}^{-3} \\
\text { BOx solution, } \\
\text { oxygen-saturated } \\
\text { (cathode) }\end{array}$ & $\begin{array}{l}\text { Carbon felt mat (5.1) } \\
\text { (both) }\end{array}$ & $\begin{array}{l}50 \mathrm{mmol} \mathrm{dm}^{-3} \text { phosphate } \\
\text { buffer } \mathrm{pH} 7.0 \text {, ionic } \\
\text { strength made to } 0.1 \text { with } \\
\mathrm{KCl} 0.5 \mathrm{mmol} \mathrm{dm}^{-3} \mathrm{MV} \\
\text { or } 0.25 \mathrm{mmol} \mathrm{dm}^{-3} \\
\text { anthroquinone } \\
\text { 2-sulphonate (AQS) } \\
\text { mediator at anode, } \\
0.25 \text { mmol dm } \\
\text { mediator at cathode }\end{array}$ & 1.17 & 176 (with MV) & 176 (with MV) & $\begin{array}{l}\text { Complete biofuel cell. } \\
\text { Current values limited by } \\
\text { BOx concentration }\end{array}$ & $\begin{array}{l}\text { Tsujimura et al. } \\
\text { (2001a) }\end{array}$ \\
\hline DET lactate $/ \mathrm{O}_{2}$ & $\begin{array}{l}\text { Suspended Shewanella } \\
\text { putrefaciens (various } \\
\text { strains) and E. coli } \\
\text { (MET), anaerobic }\end{array}$ & Graphite felt (56) (both) & $\begin{array}{l}50 \mathrm{mmol} \mathrm{dm}^{-3} \\
\text { Na-phosphate buffer } \mathrm{pH} \\
7.0,0.1 \mathrm{~mol} \mathrm{dm}^{-3} \mathrm{NaCl} \text {. } \\
\text { For some experiments } \\
\text { with } \text { E. coli anode also } \\
\text { contains } 25 \text { mmol dm } \\
\text { methylene blue }\end{array}$ & $\begin{array}{l}0.5(0.52 \text { with } \\
E . \\
\text { coli + mediator })\end{array}$ & $\begin{array}{l}0.71 \\
\text { (stabilised at } \\
0.43 \text { after } 6 \\
\text { days) }\end{array}$ & $\begin{array}{l}0.02 \text { ( } 0.01 \\
\text { stabilised after } \\
6 \text { days })\end{array}$ & $\begin{array}{l}\text { Current decrease is after } \\
\text { sequential batch operation } \\
\text { and may be due to } \\
\text { nutrient limitation or dead } \\
\text { cell contamination }\end{array}$ & Kim et al. (2002a) \\
\hline $\begin{array}{l}\text { DET/MET marine } \\
\text { sediment con- } \\
\text { stituents/seawater } \\
\text { constituents }\end{array}$ & Mixed natural bacteria & $\begin{array}{l}\text { Drilled graphite discs } \\
\text { (1830) (each) }\end{array}$ & $\begin{array}{l}\text { Seawater. Anode } 15 \mathrm{~cm} \\
\text { below sediment surface, } \\
\text { cathode } 15 \mathrm{~cm} \text { above } \\
\text { sediment surface }\end{array}$ & 0.75 & 7 & $3.2^{*}$ & $\begin{array}{l}\text { Complete biofuel cell. } \\
\text { Single compartment } \\
\text { design. Electrode area is } \\
\text { footprint of disc. } \\
\text { *Another site gave } 2.66 \\
\text { reducing to } \\
2.54 \mu \mathrm{W} \mathrm{cm}{ }^{-2} \text { over } 6 \\
\text { months }\end{array}$ & $\begin{array}{l}\text { Tender et al. } \\
(2002)\end{array}$ \\
\hline $\begin{array}{l}\text { MET lactate (also } \\
\text { pyruvate, acetate and } \\
\text { glucose }) / \mathrm{O}_{2}\end{array}$ & $\begin{array}{l}\text { Suspended Shewanella } \\
\text { putrefaciens, anaerobic }\end{array}$ & $\begin{array}{l}\text { Woven graphite }\left(^{*}\right), \\
\text { NR-woven graphite }\left(^{*}\right) \text { or } \\
\mathrm{Mn}^{4+} \text { graphite plate }(80) \\
\text { anode, } \mathrm{Fe}^{3+} \text { modified } \\
\text { graphite plate cathode } \\
\text { (50) }\end{array}$ & $\begin{array}{l}100 \text { or } 200 \mathrm{mmol} \mathrm{dm}^{-3} \\
\text { lactate, } 100 \mathrm{mmol} \mathrm{dm}^{-3} \\
\text { phosphate buffer, } \\
1 \mathrm{~g} \mathrm{dm}^{-3} \text { of each of yeast } \\
\text { extract, peptone and } \\
\mathrm{NH}_{4} \mathrm{Cl} \text {. pH } 7.0\end{array}$ & $\begin{array}{l}0.6 \text { (with } \\
\mathrm{Mn}^{4+} \text {-graphite } \\
\text { anode) }\end{array}$ & $\begin{array}{l}3.75 \text { (with } \\
\mathrm{Mn}^{4+} \text {-graphite } \\
\text { anode, after } \\
60 \mathrm{~h} \\
\text { incubation, } \\
1 \mathrm{k} \Omega \text { external } \\
\text { resistance) }\end{array}$ & $\begin{array}{l}0.94 \text { (with } \\
\mathrm{Mn}^{4+} \text {-graphite } \\
\text { anode, after } \\
60 \mathrm{~h} \\
\text { incubation, } \\
1 \mathrm{k} \text { ( external } \\
\text { resistance) }\end{array}$ & $\begin{array}{l}\text { Single compartment } \\
\text { design. }{ }^{*} \text { Woven graphite } \\
\text { anodes are } 1.27 \mathrm{~m}^{2} \\
\text { non-superficial area }\end{array}$ & $\begin{array}{l}\text { Park and Zeikus } \\
\text { (2002) }\end{array}$ \\
\hline
\end{tabular}


could be considered as such. An extensive review of the means by which various liquid and gaseous fuels could be produced using biotechnology, of which ethanol (EtOH), methanol and methane are the most potentially useful in fuel cells, was written by Kosaric and Velikonja (1995).

A product type system that can be considered as a true biofuel cell involves combining two unit operations, such that the microbial process takes place in the same compartment as the electrode reaction (Fig. 3B). Prior reviews of this type of system have been carried out (Katz et al., 2003; Palmore and Whitesides, 1994).

The fuel cell systems of Bennetto et al. (1983) were cited as the main contributor to the microbial fuel cell design currently used in gastrobotics, the construction of food powered autonomous robots and a robot, 'Gastronome', was presented at the International Conference on Robotics and Applications 2000 (Wilkinson, 2000). The proposed design uses a digestive anode compartment bacterial population, consuming a variety of fuels/foods. The initial product 'Gastronome' operates on the addition of sugar cubes as food, and as such is not autonomous, but serves as a test bed for the technology. More recently carnivorous robots aimed at hunting and eating slugs (Kelly, 2003) or trapping flies have been designed (Ieropolous et al., 2004).

Mixed mode systems showing some of the characteristics of a product type system have been developed (Tender et al., 2002); a marine biofuel cell that partly derives its power from the oxidation of sediment sulphides produced by the microbial breakdown of sedimentary organic carbon and partly from biocatalytic oxidation of the organic carbons. This biofuel cell system used uncatalysed drilled graphite disc electrodes used either 'as received' or lightly sanded. The electrodes were placed parallel to the sediment surface with the anode ca. $15 \mathrm{~cm}$ below the surface and the cathode ca. $15 \mathrm{~cm}$ above it, in water with a mid-tide depth of ca. $4 \mathrm{~m}$. The fuel cells generated approximately $26 \mathrm{~mW} \mathrm{~m}^{-2}$ at $0.27 \mathrm{~V}$ for periods of 5-6 months, with the voltage only dropping significantly during one incident in which the cathode was covered by sediment. Clearing the sediment by the use of human divers restored power production. In one environment, the power was derived ca. $40 \%$ from oxidation of biologically generated sediment sulphide, and the remainder from biocatalytic oxidation of sediment acetate. The magnitude of these two contributions would clearly depend on the specific environment. This technology produces only low power, but could be scaled up relatively easily to provide long-term power to, e.g., marine sensors.

Recently, a product type system in which electricity can be generated from macromolecules (starch), glucose or molasses via the in situ generation of hydrogen by Clostridium butyricum or Clostridium beijerinckii (Niessen et al., 2004). The anode used was platinised-woven carbon based but the platinisedwoven carbon electrode was also coated with electropolymerised poly(tetrafluoroaniline). This coating layer is claimed to prevent the platinum from becoming poisoned by the constituents of the microbial fuel cell broth. Unlike an earlier electrode design (Schroder et al., 2003), no pulsed oxidative cleaning process is required to maintain the activity of this electrode. The fuel cell system described in this paper was able to achieve cur- rent densities as high as $1 \mathrm{~mA} \mathrm{~cm}^{-2}$ when operating with starch as the electron source. The time stability of the system and the efficiency of the energy conversion, however, were not elucidated.

\subsection{Whole organism diffusive MET biofuel cells}

Living organisms use both internal and external membranes as a highly effective control of their metabolic redox processes, serving both to support and provide a suitable environment for the enzymes performing the reactions and to regulate electron and chemical movement around the cells. Without careful regulation electron transfers and reactions within the cell would lead to a uniform intracellular potential, whereupon metabolism would stop. Unfortunately for the purposes of researchers trying to produce a biofuel cell, this very regulation often makes it difficult to force a cell to 'leak' electrons to an electrode. MET biofuel cells utilising whole cells rely on the reduction (oxidation) of mediators within the cell or at the cell surface (reaction (21)) followed by their oxidation (reduction) at the anode (cathode) (reaction (22)).

$$
\begin{aligned}
& \text { substrate }+ \text { mediator }_{\mathrm{O}} \stackrel{\text { organism }}{\longrightarrow} \text { product }+ \text { mediator }_{\mathrm{R}} \\
& \text { mediator }_{\mathrm{R}} \stackrel{\text { anode }}{\longrightarrow} \text { mediator }_{\mathrm{O}}+\text { electrons }
\end{aligned}
$$

A whole range of properties are therefore desirable in such a mediator: a potential just different enough from the potential of the organism to facilitate electron transfer while maintaining a high (electrochemical) cell potential, a high diffusion coefficient in the supporting electrolyte and (possibly) through the cell membrane, rapid electron transfer at the organism and electrode, suitability for repeated redox cycles, non-cytotoxicity, and good absorption/adsorption/desorption profiles at the organism, electrode and other fuel cell surfaces so that it remains in solution and remains available for the process.

A cell has been manufactured with a biofuel cell anode compartment using 2-hydroxy-1,4-naphthoquinone (HNQ) as a mediator in solution and Proteus vulgaris bound to carbon felt anode via either an amide bond or culturing the bacteria on the anode (Allen and Bennetto, 1993). The cathodic reaction was either reduction of ferricyanide at a reticulated vitreous carbon (RVC) electrode or reduction of $\mathrm{O}_{2}$ at a platinised carbon electrode (platinised carbon paper, PCP). The anodic substrate supply was $50 \mathrm{mmol} \mathrm{dm}^{-3}$ glucose in $\mathrm{pH} 7.0$ buffer injected into the anode compartment under computer control. Optimal production of power and optimal coulombic yield from oxidation of fuel were both investigated. A comparison of anodes containing free and immobilised bacteria was performed using RVC cathodes: immobilised cells were found to have a slower response but a higher current plateau (ca. $0.5 \mathrm{~mA}$ ) than freely suspended cells (ca. $0.46 \mathrm{~mA}$ ), but the overall coulombic efficiencies were the same at $15 \%$ (under a $1 \mathrm{k} \Omega$ load). In other experiments using the oxygen PCP cathode, it was found that the open circuit voltage (OCV) achieved by free bacteria was higher than that of the immobilised bacteria $(0.75$ and $0.65 \mathrm{~V}$, respectively). On addition of glucose, the current response (closed circuit $1 \mathrm{k} \Omega$ 
external resistance) was more rapid with the immobilised cells. Both immobilised and free cells gave a stable current of ca. $0.5 \mathrm{~mA}$ at $1 \mathrm{k} \Omega$. By computer control of glucose addition, injecting substrate whenever the voltage produced dropped below $0.4 \mathrm{~V}$, a stable current of $0.4 \mathrm{~mA}$ was maintained for 5 days, only requiring intervention to maintain the $\mathrm{pH}$ of the cathodic buffer. Glucose was initially oxidised at a coulombic efficiency of $33 \%$ for $48 \mathrm{~h}$ but this stabilised at $25 \%$ after a week, this representing a doubling of the efficiency that would be achieved by a single large dose of substrate. The period of current oscillation from this fed batch operation was $22 \mathrm{~min}$ with free cells and 12 min with immobilised bacteria. This system gave a very small current density of $19.8 \mu \mathrm{A} \mathrm{cm}^{-2}$ at $1 \mathrm{k} \Omega$ load.

A biofuel cell concept has been considered (Cooney et al., 1996) in which the reduction of sulphate ions to hydrogen sulphide was driven by the oxygenation of substrate by the sulphate reducing bacterium Desulphovibrio desulphuricans. In this cell Desulphovibrio desulphuricans Essex 6 oxidised lactate or pyruvate, reducing

$\mathrm{SO}_{4}^{2-}+$ substrate $\stackrel{\text { bacteria }}{\longrightarrow} \mathrm{S}^{2-}+$ biomass + wastes

$\mathrm{S}^{2-}+4 \mathrm{H}_{2} \mathrm{O} \stackrel{\text { anode }}{\longrightarrow} \mathrm{SO}_{4}^{2-}+8 \mathrm{H}^{+}+8 \mathrm{e}^{-}$

sulphate to sulphide (23). The sulphide was then reoxidised at the anode, regenerating the sulphate (24). Their study demonstrated that for equal biomass, a higher current density was achieved by using lactate as substrate rather than pyruvate, but the pyruvate required less sulphate due to a lower production of hydrogen sulphide gas. Unfortunately, their work investigated the growth kinetics, substrate consumption and production of sulphides and acetate (by-product) but did not actually record the performance of the actual fuel cell.

Kim et al. (2000a,b) developed a Proteus vulgaris fuel cell using thionin as an anodic mediator and comparing it to safranine O. The first work optimised the operation of the fuel cell: a plateand-frame configuration with a Nafion membrane between the compartments and RVC anode. Unfortunately, the paper fails to give either a weight or pore size for the RVC, so the nonsuperficial electrode area cannot be estimated. The cathode was platinum in $0.1 \mathrm{~mol} \mathrm{dm}^{-3}$ ferricyanide solution. The best performance of the cell was at $37^{\circ} \mathrm{C}$, which is the optimum temperature for growth of $P$. vulgaris, although below a current of ca. $1 \mathrm{~mA}$ the cell voltage did not show sensitivity to temperature. The optimum concentration of thionin was found to be $0.1 \mathrm{mmol} \mathrm{dm}^{-3}$. At $0.01 \mathrm{mmol} \mathrm{dm}^{-3}$ the electron transfer to the electrode was limited by thionin concentration, and at $1 \mathrm{mmol} \mathrm{dm}^{-3}$ it was postulated that surplus oxidised thionin molecules adsorb onto the electrode surface and hinder the transfer of reduced thionin to that surface.

The second paper (Kim et al., 2000b) investigated more thoroughly how the coulombic efficiency of a series of fuel cells of the same design utilising Proteus vulgaris mediated by thionin varied with the variation of both fuel carbon source (sources used: glucose, galactose, maltose, sucrose, trehalose) and the carbon source in which the bacterium was cultivated. The cell was discharged through a $1 \mathrm{k} \Omega$ external resistance until the cell
Table 4

Percentage coulombic efficiency ${ }^{\mathrm{a}}$ for various carbon source conditions (after Kim et al., 2000b)

\begin{tabular}{llllll}
\hline $\begin{array}{l}\text { Initial carbon } \\
\text { source condition }\end{array}$ & \multicolumn{5}{l}{$\begin{array}{l}\text { Percentage coulombic efficiency for } \\
\text { various carbon sources }\end{array}$} \\
\cline { 2 - 6 } & Glucose & Galactose & Sucrose & Maltose & Trehalose \\
\hline Glu-ini & 29 & 56 & 27 & 32 & 26 \\
Gal-ini & 33 & 42 & 41 & b & 36 \\
Suc-ini & 26 & 12 & 26 & - & 0.9 \\
Mal-ini & 41 & 40 & 30 & 19 & 32 \\
Tre-ini & 39 & 63 & 48 & - & 37 \\
\hline
\end{tabular}

${ }^{a}$ Coulombic efficiency defined as the ratio of coulombic output obtained from the fuel cell vs. that calculated from the consumed quantity of carbon sources added.

b Current output hardly observed.

voltage dropped below $0.1 \mathrm{~V}$, then another injection of $0.5 \mathrm{~cm}^{3}$ fuel carbon source solution was added and a discharge curve was recorded. The coulombic efficiencies observed are presented in Table 4. It was found that after complete discharge the addition of new carbohydrate resulted in the cell recovering its initial voltage with the exception of galactose for Glu-ini (bacteria initially cultured on glucose). With galactose as fuel however the cell operated for a longer period (ca. $50 \mathrm{~min}$ ), resulting in high coulombic efficiency despite the lower voltage. Glucose showed the highest recovery rate, but the voltage dropped rapidly after 20 min resulting in a lower overall efficiency. Disaccharides generally gave a lower efficiency, with maltose giving a marginally higher efficiency than sucrose and trehalose (32, 27 and 26\%, respectively). With different initial culture conditions differing metabolic pathways were induced, giving different discharge profiles and coulombic efficiencies. The peak voltages obtained were of the order of $0.4 \mathrm{~V}$ as the system was discharged through a $1 \mathrm{k} \Omega$ external resistor. Although the system designed in this case was suitable for use as a fuel cell it was operated as a batch process with very limited amounts of substrate, and therefore gave no information about the long-term viability of fuel cells based on these systems. The duration of any changes to metabolic pathways induced by different growth media was unreported.

Choi, Kim et al. of this group later returned to this system (Choi et al., 2003b) to further investigate the properties of thionin and safranine $\mathrm{O}$ within the hydrophobic layers of cells. Once again, thionin was found to give much greater current outputs upon the addition of glucose than safranine $\mathrm{O}$ did, despite the more negative redox potential of safranine $O$. A simulated cell membrane was formed using 1- $\alpha$-phosphatidylcholine and 1,6diphenyl-1,3,5-hexatriene mixed and formed into approximately $140 \mathrm{~nm}$ unilamellar vesicles for fluorescence measurements or $1-\alpha$-phosphatidylcholine applied as a surface coating on the electrode. It was found that with safranine $\mathrm{O}$ the oxidised form could pass into the cell membrane but that once reduced by the oxidation of substrate it would remain and accumulate there, greatly reducing the fuel cell efficiency whereas thionin was not accumulated in either oxidised or reduced forms. The clear conclusion was that the dynamic (mass transport) behaviour of a diffusing mediator is as important as its electrochemical behaviour. 
Choi, Jung et al. investigated the electrochemical effects of homeoviscous adaptation (change in membrane fluidity via change in membrane fatty acid composition) in Proteus vulgaris in response to environmental shocks (Choi et al., 2003a). The bacteria were grown aerobically at $37^{\circ} \mathrm{C}$ in a nutrient broth. At the mid-log phase of growth a temperature $\left(10,25,46^{\circ} \mathrm{C}\right)$ or ethanol $(0.5,1.0,3.0 \%)$ shock was applied for $3 \mathrm{~h}$, after which the bacteria were harvested, washed and resuspended for the experiments. The fuel cell used had two nitrogen-bubbled compartments separated by Nafion membrane. An RVC anode (area unknown) was used with phosphate buffer containing $1 \mathrm{mg}$ dry wt. $\mathrm{cm}^{-3}$ microorganism and $1 \mu \mathrm{mol}$ thionin mediator as the anolyte. The cathode was a platinum plate, with $0.1 \mathrm{~mol} \mathrm{dm}^{-3}$ ferricyanide solution as catholyte. Upon the addition of $1 \mu \mathrm{mol}$ glucose to the anode compartment the current was recorded with time with a $560 \Omega$ external resistance and the coulombic yields were calculated from this for bacteria exposed to each type of shock. Cold temperature shocks slightly increased the maximum current output and also the coulombic yield $\left(0.69 \mathrm{C}\right.$ at $37^{\circ} \mathrm{C}, 0.73 \mathrm{C}$ at $10^{\circ} \mathrm{C}, 0.76 \mathrm{C}$ at $\left.25^{\circ} \mathrm{C}\right)$, but the high temperature shock at $46^{\circ} \mathrm{C}$ resulted in a drastic decrease in both current output and coulombic yield $(0.25 \mathrm{C})$. $P$. vulgaris can grow at $46^{\circ} \mathrm{C}$, so this decrease is not due to death of the organism, but rather to changes in the cell membrane lipid composition. After having experienced ethanolic shock, the maximum currents and coulombic outputs reduced as the percentage of ethanol used in producing the shock was increased $(0.71 \mathrm{C}$ at $0 \% \mathrm{EtOH}, 0.64 \mathrm{C}$ at $0.5 \% \mathrm{EtOH}, 0.48 \mathrm{C}$ at $1 \% \mathrm{EtOH}$, and $0.40 \mathrm{C}$ at $3 \% \mathrm{EtOH})$. Chromatography analysis of the degree of saturation of cell membrane lipids showed that the various shocks caused the bacteria to change the composition of their cell membranes to maintain their integrity and the electrochemical measurements demonstrated that this change can have significant effects on the ability of thionin mediator to penetrate the cell. Cyclic voltammetry of extracted lipids on a glassy carbon electrode demonstrated that after high temperature (or ethanolic) shock the membrane compositions excluded the thionin. These results show that the cell membrane composition can be varied by culturing cells in different conditions and that such changes can have dramatic effects on the effectiveness of the mediator molecules for electron transfer. This paper did not produce longer term results, being limited to batch operation with the experiments limited to an hours duration. It is unknown to what extent and how quickly the membrane composition recovers its unshocked state. This is an important area for future study.

Park and Zeikus studied the relationships between different bacterial cultures and electron mediators (Park and Zeikus, 2000). The properties of neutral red (NR) and thionin for NADH (the reduced form of NAD) oxidation were determined and compared. NR was found to be a better electron mediator than thionin for enhancing electricity production from glucose in a biofuel cell system using either E. coli or Actinobacillus succinogenes. The effect of growth phase of organisms was investigated. Biofuel cell experiments performed with a mixed microbial culture (sewage sludge) were described, showing that electricity could be produced during waste-water treatment. The fuel cell used for these experiments used carbon felt electrodes separated by Nafion membrane. Either NR or thionin in phosphate buffer was used as anolyte with phosphate buffer plus $50 \mathrm{mmol} \mathrm{dm}^{-3}$ ferricyanide as catholyte. The best current density achieved under load was $0.085 \mu \mathrm{A} \mathrm{cm}^{-2}$ with a cell potential of $0.62 \mathrm{~V}$ with an external resistance of $120 \Omega$, and an initial glucose concentration of $111 \mathrm{mmol} \mathrm{dm}^{-3}$. The system was stable for $118 \mathrm{~h}$. As this was a batch system it is unclear whether the stability limit was simply due to falling substrate concentration, but comparison with figures for smaller initial glucose supplies suggest otherwise since a similar system with one tenth the initial amount of glucose remained stable for $32 \mathrm{~h}$.

Tsujimura et al. (2001a) demonstrated a $\mathrm{H}_{2} / \mathrm{O}_{2}$ biofuel cell operating at ambient temperature and neutral $\mathrm{pH}$. The anodic reaction was methyl viologen (MV) mediated hydrogenase activity of Desulphovibrio vulgaris. The cathodic reaction was the $\mathrm{ABTS}^{2-}$ mediated reduction of oxygen by bilirubin oxidase (BOx) in free solution. Carbon felt electrodes were used in both compartments. The biofuel cell system achieved an open circuit potential of $1.17 \mathrm{~V}$, close to the standard value of $1.23 \mathrm{~V}$ for the reaction $\mathrm{H}_{2}+1 / 2 \mathrm{O}_{2} \rightarrow \mathrm{H}_{2} \mathrm{O}$. The $E_{\text {cell }}$ remained at $1.0 \mathrm{~V}$ with a current of $0.9 \mathrm{~mA}$ but rapidly fell to zero at $1 \mathrm{~mA}$ (catholyte $0.1 \mu \mathrm{mol} \mathrm{dm}{ }^{-3}$ BOx and $0.4 \mathrm{mmol} \mathrm{dm}^{-3} \mathrm{ABTS}^{2-}$, anolyte $D$. vulgaris $(\mathrm{H})$ at absorbance at $610 \mathrm{~nm}=10$ and $1.5 \mathrm{mmol} \mathrm{dm}^{-3}$ $\mathrm{MV}^{2+}$ ). The maximum current was found to be controlled by the rate of the cathode reaction, and was dependent on the BOx concentration. The duration of this system was only given as 'at least $2 \mathrm{~h}$ ' and the study of the chemistry governing the lifetime of the cell was identified as the next direction for research.

It has been noted from the work of Park et al. (2001) that a biofuel cell culture consortium can enrich itself over a period of time. This process and the nature of electron transfer between suspended and attached bacteria in a biofuel cell were studied over several months by Rabaey et al. (2004). Bacteria obtained from a methanogenic sludge from a potato-processing plant were placed in a fuel cell system. Following nine cultivation stages each lasting a week, at the end of each of which bacteria growing on the graphite anode were removed and resuspended to inoculate the next stage, both the suspended and attached bacteria in the system were removed and used to inoculate the test biofuel cell. After 2 weeks of operation the anode suspension was removed and replaced, with the removed suspension being inserted into a second test cell so that the performances of the free and attached bacteria could be compared. From this point operation was maintained for a further 155 days. The culture composition was tracked using denaturing gradient gel electrophoresis, which revealed that the culture composition changed over time, although the reasons for this were not entirely clear and the authors concluded that it would be desirable to avoid this for future experiments (although culture composition variation had no noticeable effect on fuel cell stability). This also revealed that by the end of the 155-day culture period the suspended and attached microbial consortia were similar.

The coulombic efficiency and power output of the cell increased during the initial enrichment period, with the electron recovery rate from the carbon source increasing from $4 \%$ (initially) to $81 \%$ and the power output increasing form $0.65 \mathrm{~W} \mathrm{~m}^{-2}$ 
to a maximum of $4.31 \mathrm{~W} \mathrm{~m}^{-2}$. Hydrogen concentrations in the headspace decreased from $43 \%$ to below detection limits. Methanogenesis was largely suppressed from the beginning of the experiments onwards. The maximum power output occurred in the cell which was initially inoculated with the suspended bacteria only. When the electrolytically active bacteria were cultured in the same broth without an electrode present they were found to rapidly revert to utilising $\mathrm{H}^{+}$as the terminal electron acceptor, indicated by hydrogen evolution. At the end of the 155 days operation, some of the bacterial species in the fuel cell were isolated by plating on Agar gel and it was possible to identify that some of the isolates excreted a mediator molecule, phenazine pyocyanin. The electrochemical activity of some of these isolates grown in a biofuel cell was compared with that of the same species grown anaerobically without an electrode, and was found to be five times greater. Some of the bacteria in the consortium were found to connect directly with the electrode via cell wall-associated mediator molecules, others excreted redox mediating molecules. Amongst other things, this finding indicates that bacterial cultures which appear not to be effective in the short-term may develop an electrical connection to an anode over a longer period.

A similar biofuel cell system (using an enriched culture presumably arising from the same source) was used by the same group to investigate the effects of loading rates (i.e. substrate supply per unit volume per unit time) (Rabaey et al., 2003). A mixed bacterial culture obtained after 5 months of enrichment in a biofuel cell (as above) was used, and glucose was used as the carbon source at feed rates from 0.5 to $5 \mathrm{~g}(\mathrm{COD}) \mathrm{dm}^{-3} \mathrm{day}^{-1}$ $(0.04 \mathrm{~g}$ [COD] corresponds to $1 \mathrm{~g}$ [glucose]), although the feed was conducted in a batch rather than continuous manner. The coulombic efficiencies, biomass and volatile fatty acid production were tabulated and compared, revealing that at low feed rates the coulombic efficiency is highest $(89 \%$ at $\left.0.5 \mathrm{~g}(\mathrm{COD}) \mathrm{dm}^{-3} \mathrm{day}^{-1}\right)$ and that above a certain feed concentration (ca. $3 \mathrm{~g}$ (COD) $\mathrm{dm}^{-3} \mathrm{day}^{-1}$ ) the coulombic efficiency dropped dramatically (77\% at $2.5 \mathrm{~g}(\mathrm{COD}) \mathrm{dm}^{-3} \mathrm{day}^{-1}, 65 \%$ at $3.0 \mathrm{~g}(\mathrm{COD}) \mathrm{dm}^{-3} \mathrm{day}^{-1}, 19 \%$ at $\left.3.5 \mathrm{~g}(\mathrm{COD}) \mathrm{dm}^{-3} \mathrm{day}^{-1}\right)$. At high feed rates it appeared that the mode of metabolism changed from outwardly oxidative to fermentative as the biomass production was approximately constant across feed rates (except at the lowest extreme of $0.5 \mathrm{~g}(\mathrm{COD}) \mathrm{dm}^{-3} \mathrm{day}^{-1}$ feed where the biomass production was much lower), but at $3 \mathrm{~g}(\mathrm{COD}) \mathrm{dm}^{-3} \mathrm{day}^{-1}$ and above the volatile fatty acid concentration rapidly increased, reducing the $\mathrm{pH}$ (below $3 \mathrm{~g}(\mathrm{COD}) \mathrm{dm}^{-3}$ day $^{-1}$ the volatile fatty acid concentrations in the fermentation broth actually decreased over the course of the experiment). This work suggested that the problem in biofuel cell development is not energy conversion efficiency (which at $>80 \%$ is high), but energy conversion rate-for other green energy systems such as anaerobic digestion a feed rate of $5-25 \mathrm{~g} \mathrm{dm}^{-3}$ day $^{-1}$ is cited.

\subsection{Whole organism non-diffusive biofuel cells}

Direct electron transfer in microbial biofuel cell systems is achieved by culture of organisms on the electrode surface, com-
(A)
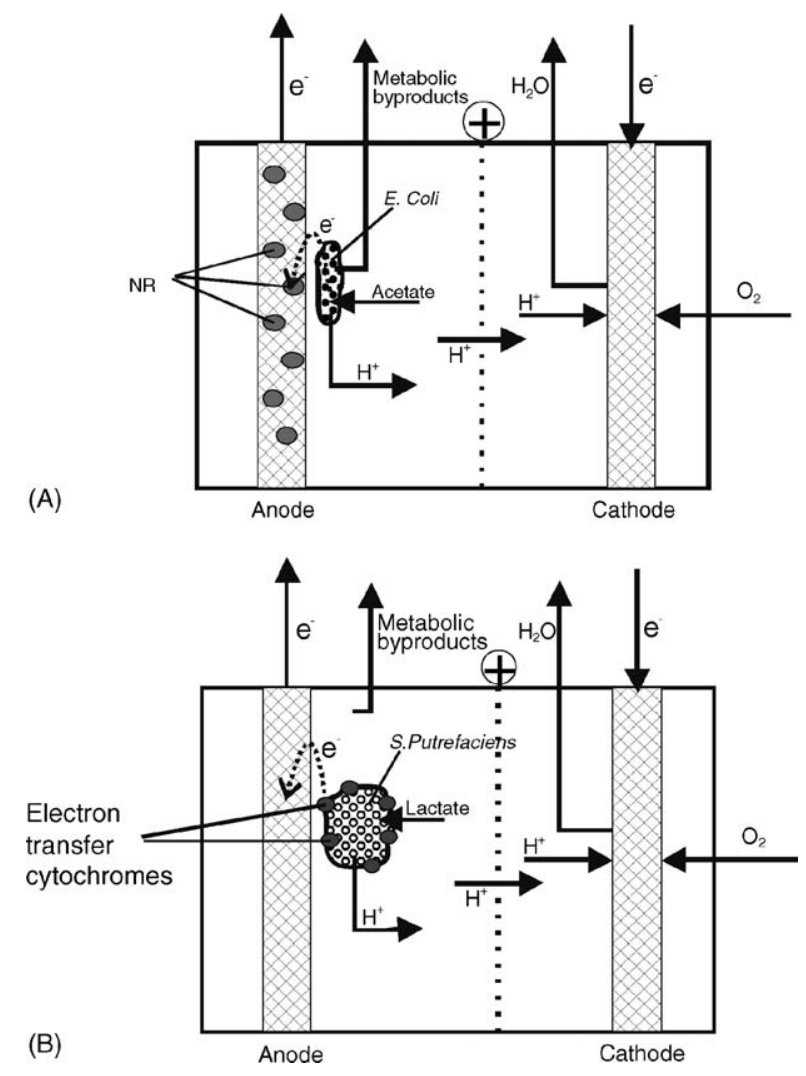

Fig. 4. MET and DET processes. (A) Schematic illustrating non-diffusive MET in this case between $E$. coli and a neutral red (mediator) modified carbon electrode after (Park et al., 2000). (B) Schematic showing how naturally occurring cytochromes in the outer membrane of some organisms can permit DET to an unmodified electrode, in this case with S. putrefaciens (after Kim et al., 1999).

bined with either a surface modified to accept electrons from the cell through incorporation of a mediator or metal ion system (non-diffusive MET), or an organism with electron transfer groups naturally (or through genetic modification) incorporated into the cell membrane (DET) (Fig. 4).

A fuel cell-based biosensor using direct electron transfer between a suspension of Shewanella putrefaciens IR-1 and a graphite felt anode was demonstrated by Kim et al. (1999). The anode compartment was continuously sparged with oxygen free nitrogen to maintain anoxic conditions and to provide agitation. The cathode was RVC with potassium ferricyanide in the catholyte. Lactate solutions of known concentration were added to the anolyte and the change in current was recorded at $5 \mathrm{~s}$ intervals. Currents through a $500 \Omega$ external resistance were found to increase to a plateau of ca. $2 \mu \mathrm{A}$, and a somewhat crude correlation between the initial rate of current increase and the lactate concentration in the sample was found. The potential of this as a power generating fuel cell was not investigated and the experiments were only of a few hundred seconds duration.

Park et al. (2000) immobilised the mediator neutral red on a carbon electrode surface to obtain non-diffusive electron transfer from $E$. coli oxidising acetate. The experiment was conducted using both a mediator-modified electrode and a native one in the anode compartment. With the native electrode the electricity production was much lower and the bacterial growth 

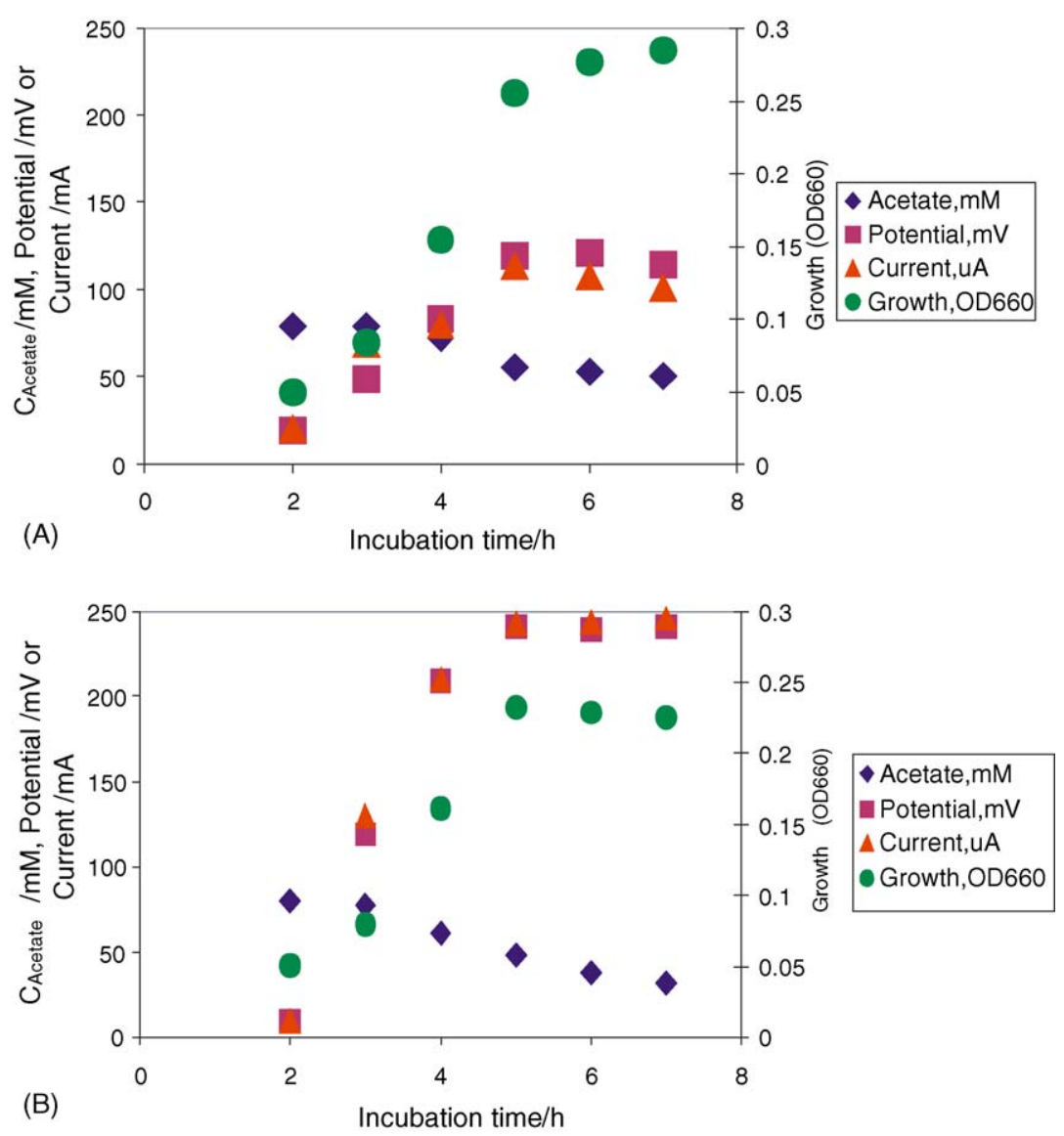

Fig. 5. Illustration of the effect of modifying an electrode with a mediator, in this case neutral red. (A) Electricity production in a two compartment biofuel cell using E. coli and unmodified graphite plate electrodes. (B) The same system with the anode modified by covalent attachment of neutral red (after Park et al., 2000).

was only very weakly influenced by the electricity production $\left(1.44 \mathrm{mV}, 1.41 \mu \mathrm{A} \mathrm{cm}^{-2}, 21 \mathrm{mmol} \mathrm{dm}^{-3}\right.$ acetate consumed in $30 \mathrm{~h}$, Fig. 5A). With the NR-modified anode the growth was inhibited by electricity production despite more substrate being consumed $\left(3.12 \mathrm{mV}, 3.10 \mu \mathrm{A} \mathrm{cm}^{-2}, 39 \mathrm{mmol} \mathrm{dm}^{-3}\right.$ acetate consumed in $30 \mathrm{~h}$, Fig. 5B). No comment was made in the paper on the time stability of the system, as the paper was simply a feasibility study on the system.

Kim et al. (2002a) investigated the mediatorless electron transfer properties of various different strains of Shewanella putrefaciens and of E. coli (NCIB 10772). The bacteria were employed as a cell suspension in the anode compartment of the fuel cell, which was nitrogen bubbled to maintain anaerobic conditions. Both electrodes were graphite felt and the cathode reduced supplied oxygen. Ten millimoles per cubic decimetre of lactate was used as the fuel fed to the anode compartment when the bacteria used were S. putrefaciens, and glucose $\left(10 \mathrm{mmol} \mathrm{dm}^{-3}\right)$ was used in the $E$. coli based fuel cell. It was found that anaerobically grown suspensions of all S. putrefaciens were electrochemically active, but aerobically grown cell suspensions were not, and that $E$. coli exhibited no electrochemical activity. In the fuel cell the $E$. coli suspension showed no increase in potential (from $0.03 \mathrm{~V}$ ) on $10 \mathrm{mmol} \mathrm{dm}^{-3}$ glucose addition. When $25 \mathrm{mmol} \mathrm{dm}^{-3}$ methylene blue mediator was added the potential increased to $0.52 \mathrm{~V}$. S. putrefaciens suspensions gave an initial potential of ca. $0.2 \mathrm{~V}$, which rose to $0.44-0.55 \mathrm{~V}$ on the addition of $10 \mathrm{mmol} \mathrm{dm}^{-3}$ lactate, depending on strain. Currents of $0.03-0.04 \mathrm{~mA}\left(0.6-0.8 \mu \mathrm{A} \mathrm{cm}^{-2}\right)$ were generated by the $S$. putrefaciens strains with $1 \mathrm{k} \Omega$ external resistance (no current was generated by unmediated $E$. coli). In a sequential batch operation the current produced by the IR-1 strain declined from 0.039 to $0.025 \mathrm{~mA}$ over 6 days but then stabilised somewhat at $0.02 \mathrm{~mA}$ after 8 days, a similar trend (decrease and then stabilise) occurring in the coulombic yield. This pattern was explained as being caused either by nutrient limitation or by the presence of contaminants metabolising the dead cells and substrate. The bacterial strain may have developed a protective mechanism to reduce the loss of energy to the electrode.

Tender et al. (2002) deployed a biofuel cell in a marine environment as described above under product type microbial biofuel cells. Reference is made here as the action of the microbes involved was partially direct electrocatalysis by microbes colonising the electrode surface.

A DET based biofuel cell completely oxidising glucose to $\mathrm{CO}_{2}$ and water has recently been described by Chaudhuri and Lovley (2003). Rhodoferax ferrireducens was employed, and was found to be able to achieve coulombic efficiencies for glucose conversion of $83 \%$ at plain graphite electrodes (rod, foam and woven graphite). Under excess glucose $\left(10 \mathrm{mmol} \mathrm{dm}^{-3}\right)$ the cell was able to sustain $3.1 \mu \mathrm{A} \mathrm{cm}^{-2}$ at $265 \mathrm{mV}\left(0.8 \mu \mathrm{W} \mathrm{cm}{ }^{-2}\right)$ 
with $R_{\mathrm{e}}=1000 \Omega$ (actual current $0.20 \mathrm{~mA}$ ) for approximately 27 days (after approximately 6 days start-up following bacteria addition). Although the power density of this cell is very low, the coulombic efficiency is high and it is more readily scalable than many enzyme based designs. The concentrations of fuel $\left(0.36 \mathrm{~g} \mathrm{dm}^{-3}\right.$ glucose $)$ used in this system are very low and the work of Rabaey et al. (2003) suggested that increased fuel concentrations $\left(75 \mathrm{~g} \mathrm{dm}^{-3}\right.$ was an upper limit for high coulombic efficiency) may lead to a drop in efficiency and that the major barrier to a practical biofuel cell is now conversion rate rather than coulombic efficiency.

Gil et al. (2003) attempted to quantify the effects of changing various parameters based around an already optimised mediatorless biofuel cell. The bacterium used was probably Clostridium butyricum EG3, as isolated from a biofuel cell that has been operated on a starch plant waste-water for over 3 years (Park et al., 2001), but it is unclear whether this isolate or a mixed culture from the biofuel cell was used. The research attempted to identify rate-limiting factors in the steps of oxidation of fuel, electron transfer (cells $\rightarrow$ anode), external electric load, proton transfer through membrane and oxygen supply at cathode. The possibility of mass transfer limits on substrate at the anode was not considered. The fuel cell system operated at $37^{\circ} \mathrm{C}$ and used carbon felt electrodes separated by a Nafion membrane; the anode compartment was continuously purged with nitrogen. The cathode compartment was initially set up with $\mathrm{pH} 7.0$ phosphate buffer and $100 \mathrm{mmol} \mathrm{dm}^{-3} \mathrm{NaCl}$ electrolyte and the anode compartment contained starch plant wastewater diluted to $400 \mathrm{mg} \mathrm{dm}^{-3}$ chemical oxygen demand (COD) with the same electrolyte. Variation of $\mathrm{pH}$ in the anode compartment demonstrated an optimal $\mathrm{pH}(7-8)$ for maximum current (ca. $0.22 \mathrm{~mA}$ ) and coulombic output. Variation of the external load demonstrated a rate limiting effect for external load $>500 \Omega$, with a low level but steady current maintained for over $30 \mathrm{~h}$. At lower external resistances of 10 and $100 \Omega$ the current rapidly reached a maximum peak and then decreased rapidly to two shoulders, showing that the rate limiting step at over $500 \Omega$ was the external resistance; below $200 \Omega$ the rate limit is due to a limited supply of either protons or oxygen reaching the cathode. The coulombic output decreased as the external resistance was increased, probably indicating that limiting the current output encourages side reactions leading to the use of alternate electron acceptors, such as oxygen diffused through the membrane. The third experiment varied the electrolyte composition using wastewater diluted to COD $100 \mathrm{ppm}$. Removing the $\mathrm{NaCl}$ from the buffer caused a slight decrease in the peak current measured $(1.35 \mathrm{~mA} \rightarrow 1.20 \mathrm{~mA})$, presumably attributable to a reduction in conductivity, while removing the phosphate drastically reduced it to ca. $0.45 \mathrm{~mA}$, and using distilled water gave ca. $0.50 \mathrm{~mA}$. The coulombic output showed the same trend (phosphate $+\mathrm{NaCl}>$ phosphate alone $>$ distilled $\mathrm{H}_{2} \mathrm{O}>\mathrm{NaCl}$ alone). The lower limit on the conductivity and coulombic output presumably indicate the effects of the wastewater itself. A fourth experiment compared $\mathrm{pH}$ change of the fuel cell with buffer and with distilled water. Within $10 \mathrm{~h}$, the $\mathrm{pH}$ of the anode operating with distilled water had dropped to 5.4 and the catholyte $\mathrm{pH}$ had risen to over 9.5. In contrast, the control (buffered) system changed $\mathrm{pH}$ by less than 0.5 units in each compartment. This demonstrated that proton transfer across the membrane was slower than both consumption of protons in the cathode and generation of protons in the anode and that buffer is required to maintain optimal microbial activities. A single compartment design was commended on grounds of avoiding this problem. A comparison between aerating the cathode compartment and using air-saturated buffer feed to the cathode showed that aeration is required to avoid a mass transfer rate limit at the cathode. The authors assert that this demonstrates that the dissolved oxygen level is the major limiting factor in the operation of a microbial fuel cell where graphite is used as the electrode, but it is possible that the aeration introduced turbulence and hence simply improved the mass transport of oxygen to the cathode.

Kim et al. (2003a) reported a BOD sensor based on this fuel cell using measurement of the coulombic output. The sensor had the drawback that it could take up to $10 \mathrm{~h}$ to measure the BOD of a sample (sample at $206.4 \mathrm{ppm}$ BOD), but the advantage that provided an unlimited supply of fuel (in this case wastewater from the starch plant) is available the sensor is viable for at least 5 years. The culture upon which the anode was based was enriched by utilising the wastewater the experiments were based on however, so this particular sensor may give different performance if a substrate (test stream) has a different BOD chemical composition, and may require recalibrating over long periods as the culture enriches further.

Park and Zeikus (2003) investigated electron transfer in a single compartment biofuel cell using $E$. coli and oxidising lactate using carbon plate electrodes doped with $\mathrm{Fe}^{3+}, \mathrm{Mn}^{4+}$ or woven graphite felt - bonded neutral red. The surface concentration of NR was estimated at $30 \mu \mathrm{mol} \mathrm{dm}{ }^{-3}$ NR by cyclic voltammetry of the electrode. The metal ions were incorporated into a kaolin (porcelain clay)/graphite plate. Two fuel cell designs were used: in a two compartment system a proton-permeable kaolin septum was used to separate the two compartments, and the catholyte required the aeration and addition of ferricyanide mediator. The single compartment fuel cell was achieved by attaching a $1 \mathrm{~mm}$ kaolin septum to the surface of the $\mathrm{Fe}^{3+}$-graphite cathode during its manufacture. This cathode was then window mounted with the proton-permeable kaolin side inwards. The modified electrodes enhanced the power density for both fuel cells based on $E$. coli and on mixed sewage sludge culture, with the combination of the manganate anode and the ferric cathode being the most effective. Comparing the electricity produced by the NRmodified graphite felt and soluble NR with graphite felt electrode (Park and Zeikus, 2000) the soluble NR system obtained a maximum potential of $0.65 \mathrm{~V}$ and maximum current density of $0.47 \mathrm{~mA} \mathrm{~g}^{-1}$ woven graphite, where the NR-modified graphite developed $0.35 \mathrm{~V}$ and $1.2 \mathrm{~mA} \mathrm{~g}^{-1}$ woven graphite. The modified electrodes were found not to develop as great a potential as the redox couples they were based upon, but pass equal or greater current due to better electron transfer kinetics.

This work was followed by a comparison of the effect of changing electron donors (substrates), cell concentrations and circuitry design on electricity production by resting cells of $S$. putrefaciens (Park and Zeikus, 2002). The same type of fuel cell as with the previous study was used; a single compartment fuel 
cell using a kaolin septum to permit proton transfer to a $\mathrm{Fe}^{3+}$ graphite plate cathode and anodes of woven graphite, neutral red-linked woven graphite or $\mathrm{Mn}^{4+}$-graphite plate. Harvested and washed bacterial cell suspensions were placed into the compartment at optical densities at $660 \mathrm{~nm}\left(\mathrm{OD}_{660}\right)$ of 0.5-4.0 (cell protein of $978 \mathrm{mg} \mathrm{dm}^{-3}$ cell suspension gives $\mathrm{OD}_{660}=1.0$ ) to investigate the effect of cell concentration. It was found that in this system lactate was the most effective electron donor, closely followed by pyruvate and that acetate and glucose were very poor electron donors using either the NR-modified or $\mathrm{Mn}^{4+}$ anodes (based on current density). The unmodified graphite electrode was ineffective when compared with either of the modified electrodes. As the lactate concentration was increased (with cell concentration at $\mathrm{OD}_{660}=4.0$ ) the current increased approximately linearly up to $150 \mathrm{mmol} \mathrm{dm}^{-3}$ lactate, at which point the current levelled off (the authors asserted excess at $200 \mathrm{mmol} \mathrm{dm}^{-3}$ lactate but the figures showed that this was conservative). When using $200 \mathrm{mmol} \mathrm{dm}^{-3}$ lactate as electron donor the electricity produced increased as the cell concentration was increased up to $\mathrm{OD}_{660}$ of 3.0 ( $2.9 \mathrm{~g} \mathrm{l}^{-1}$ protein) at which point the cells were in excess, which can be interpreted as the electrode surface being completely covered.

\subsection{Photomicrobial fuel cells}

Photomicrobial fuel cells have much in common with other microbial fuel cells, differing only in that the energy converted to electricity comes originally from a light source rather than a fuel substrate, and the additional requirement that any mediator used needs to be light-stable. Two operating modes can be considered; firstly, energy can be produced and stored by the cells during illumination and later released and processed as with a non-photosynthetic biofuel cell, or secondly the energy may be extracted by a mediator transporting electrons during illumination. A single photosynthetic fuel cell may be capable of both of these modes of action. Recent examples include the work of Seon et al. (1993), Yagishita et al. (1999) and Tsujimura et al. (2001b).

Seon et al. (1993) constructed a photomicrobial hydrogen generating bioreactor using immobilised Rhodospirillum rubrum KS-301 in Ca-alginate beads. A nozzle loop configuration was used to reduce the mass transfer resistances in the reactor by circulating the substrate continuously.

Yagishita et al. (1999) investigated the effects of glucose addition and light on the current output of a photomicrobial fuel cell using Synechocystis sp. PCC6714. The current output was found to be dependent on both the photosynthetic and respiratory activity of the cyanobacterium.

Tsujimura et al. (2001b) produced a photomicrobial biofuel cell with no special fuel requirement, in which the photosynthetic anodic reaction is the oxidation of water to produce dioxygen and protons. This was done using Synechococcus sp. PCC7942 and either 2,6-dimethyl-1,4-benzoquinone (DMBQ) or diaminodurene (DAD) as a mediator in the anode compartment. In the cathode compartment $\mathrm{BOx}$ was used as a biocatalyst with $\mathrm{ABTS}^{2-}$ as a mediator. The maximum power obtained from the cell was $0.13 \mathrm{~mW}\left(29 \mu \mathrm{W} \mathrm{cm}{ }^{-2}\right.$ projected surface area) at a potential of $0.26 \mathrm{~V}$ with a $500 \Omega$ external

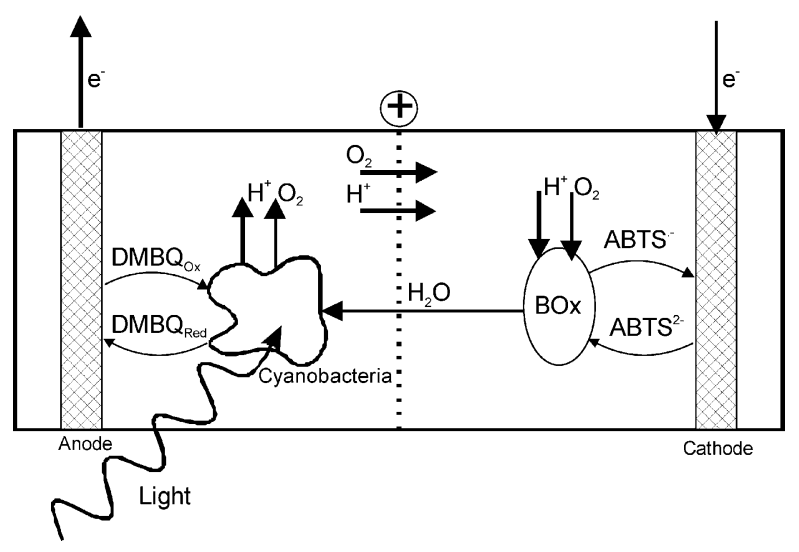

Fig. 6. A photomicrobial biofuel cell after (Tsujimura et al., 2001b), employing a photosynthetic cyanobacterium in the anode compartment using incident light to oxidise water to $\mathrm{O}_{2}$ and $\mathrm{H}^{+}$ions, and to reduce DMBQ (a mediator molecule). The DMBQ is reoxidised at the anode as the direct electrode reaction. In the cathode compartment $\mathrm{O}_{2}$ is reduced back to water by bilirubin oxidase mediated by ABTS, completing a cyclic reaction.

resistance. The efficiency of light energy conversion was calculated to be $1.9 \%$ (Fig. 6).

\section{Fuel cells utilising a purified enzyme}

Fuel cells making use of a purified enzyme have arisen from a desire to have specific and defined reaction(s) occurring in the fuel cell. Many proposed uses for this type of system are in vivo applications, such as self-powering glucose sensing for use in diabetics (Katz et al., 2001; Quinn et al., 1997) or the long-standing goal of the implantable power supply for a cardiac pacemaker. As such, several technologies for DET and MET biofuel cells of this type have developed in parallel or associated with biosensor technology and have previously been reviewed from this angle (Habermuller et al., 2000; Willner et al., 1997). Biofuel cells have different requirements than biosensors however, and electrode fabrication methods involving entrapment in conductive polymer (for example those reviewed by Cosnier (1999)) are often less ideal for biofuel cells due to the establishment of unnecessary diffusional resistances in the entrapment matrix. The exception to this last generalisation is if a biofuel cell can be constructed as a membrane electrode assembly (MEA), as the short diffusional distances compensate for the more convoluted diffusion path. This configuration has recently been achieved (Akers and Minteer, 2003; Akers et al., 2005). Recent examples of demonstrated biofuel cells employing purified enzymes are summarised in Table 5.

\subsection{Enzymatic product type systems}

It is much less common to use purified enzymes in a product type system than it is to use complete microorganisms, but the principle is the same. Product type systems operating with purified enzymes harvesting hydrogen from a substrate through the paired action of a hydrogenase and a dehydrogenase enzyme have been demonstrated (O'Neill and Woodward, 2000; Woodward et al., 1996). The hydrogen is then utilised in 


\begin{tabular}{|c|c|c|c|c|c|c|c|c|}
\hline $\begin{array}{l}\text { System } \\
\text { (oxidation/reduction) }\end{array}$ & $\begin{array}{l}\text { Bio- } \\
\text { catalyst(s) }\end{array}$ & Electrodes $\left(\right.$ area $/ \mathrm{cm}^{2}$ ) & Electrolyte & $\mathrm{OCV} / \mathrm{V}$ & $\begin{array}{l}\text { Current } \\
\text { density } \\
\left(\mu \mathrm{Acm}^{-2}\right)\end{array}$ & $\begin{array}{l}\text { Power density } \\
\left(\mu \mathrm{A} \mathrm{cm}^{-2}\right)\end{array}$ & Comments & Reference \\
\hline \multicolumn{9}{|c|}{ (A) Fuel cells not based on the '2-fibre' biofuel cell design } \\
\hline $\begin{array}{l}\mathrm{MET} \mathrm{CH}_{3} \mathrm{OH} \text { to } \\
\mathrm{H}_{2} \mathrm{CO} \text { to } \\
\mathrm{HCOOH} \text { to } \mathrm{CO}_{2}, \\
\text { reducing } \mathrm{NAD}^{+}, \\
\mathrm{NADH} \text { reducing } \\
\mathrm{BV}^{2+}, \\
\mathrm{BV}^{+} / \text {oxygen }\end{array}$ & $\begin{array}{l}\text { ADH, AldDH, } \\
\text { FDH and } \\
\text { diaphorase }\end{array}$ & $\begin{array}{l}\text { Graphite plate anode (2), } \\
\text { platinised platinum gauze } \\
\text { cathode (3) }\end{array}$ & $\begin{array}{l}1 \mathrm{~mol} \mathrm{dm}^{-3} \mathrm{LiCl} \text {, } \\
0.1 \mathrm{~mol} \mathrm{dm}^{-3} \mathrm{Tris} \text { buffer } \\
\mathrm{pH} 7.5 . \text { Anolyte also } \\
0.1 \mathrm{~mol} \mathrm{dm}^{-3} \mathrm{CH}_{3} \mathrm{OH} \text {, } \\
1.0 \mathrm{mmol} \mathrm{dm}^{-3} \mathrm{NAD}^{+} \text {, } \\
50 \mathrm{mmol} \mathrm{dm}^{-3} \mathrm{BV}^{2+} \text { and } \\
\text { argon purged and } \\
\text { blanketed. Catholyte } \mathrm{O}_{2} \\
\text { saturated. }\end{array}$ & 0.8 & 2.6 & $680($ at $0.49 \mathrm{~V})$ & $\begin{array}{l}\text { Voltage drops due to } \\
\text { depletion of } \mathrm{BV}+\text {, but can } \\
\text { be returned to initial open } \\
\text { circuit values by removal of } \\
\text { load within an } 8 \mathrm{~h} \text { period }\end{array}$ & Palmore et al. (1998) \\
\hline $\begin{array}{l}\text { MET glucose/MET } \\
\qquad \mathrm{H}_{2} \mathrm{O}_{2}\end{array}$ & GOx/MP-11 & $\begin{array}{l}\text { Apo-GOx reconstituted on } \\
\text { PQQ-FAD monolayer } \\
\text { associated with gold wire } \\
\text { anode }(0.2) \text {, MP-11 coupled } \\
\text { to cystamine monolayer on } \\
\text { gold wire cathode }(0.2)\end{array}$ & $\begin{array}{l}0.1 \mathrm{~mol} \mathrm{dm}^{-3} \text { phosphate } \\
\text { buffer } \mathrm{pH} 7.0 \text {. Anolyte } \\
\text { also } 1 \mathrm{mmol} \mathrm{dm}{ }^{-3} \\
\text { glucose. Catholyte also } \\
1 \mathrm{mmol} \mathrm{dm}^{-3} \mathrm{H}_{2} \mathrm{O}_{2}\end{array}$ & 0.32 & 1.7 & $\begin{array}{l}160 \text { (at } 3 \mathrm{k} \\
\text { ( external load) }\end{array}$ & $\begin{array}{l}\text { Complete biofuel cell. Short } \\
\text { circuit current density } \\
\text { limited by GOx. Outputs the } \\
\text { same under Ar or air. Power } \\
\text { output decreased by } 50 \% \\
\text { after ca. } 3 \text { h. Half of the loss } \\
\text { attributed to substrate } \\
\text { consumption }\end{array}$ & Willner et al. (1998b) \\
\hline $\begin{array}{l}\text { MET NADH/MET } \\
\mathrm{H}_{2} \mathrm{O}_{2}\end{array}$ & $-/ \mathrm{MP}-11$ & $\begin{array}{l}\text { PQQ monolayer } \\
\text { functionalised gold wire } \\
\text { anode }(0.2), \text { MP- } 11 \text { coupled } \\
\text { to cystamine monolayer on } \\
\text { gold wire cathode }(0.2)\end{array}$ & 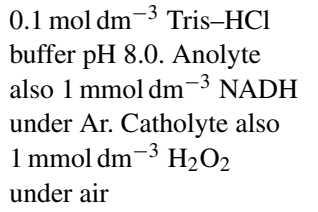 & 0.31 & 0.5 & $\begin{array}{l}40 \text { (at } 3 \mathrm{k}( \\
\text { external load) }\end{array}$ & Stability not investigated & Willner et al. (1998a) \\
\hline $\begin{array}{l}\text { MET glucose/MET } \\
\text { cumene peroxide }\end{array}$ & GOx/MP-11 & $\begin{array}{l}\text { Apo-GOx reconstituted on } \\
\text { PQQ-FAD monolayer } \\
\text { associated with gold disc } \\
\text { anode }(0.126) \text {, MP- } 11 \\
\text { coupled to cystamine } \\
\text { monolayer on gold disc } \\
\text { cathode }(0.126)\end{array}$ & $\begin{array}{l}\text { Anolyte } 0.01 \mathrm{~mol} \mathrm{dm}^{-3} \\
\text { phosphate buffer pH } 7.0 \\
\text { and } 0.05 \mathrm{~mol} \mathrm{dm}^{-3} \\
\text { TBATFB. Catholyte } \\
\text { dichloromethane with } \\
0.05 \mathrm{~mol} \mathrm{dm}^{-3} \text { TBATFB }\end{array}$ & 0.99 & 14.3 & $\begin{array}{l}5140 \text { (at } 0.4 \mathrm{k}( \\
\text { external load) }\end{array}$ & $\begin{array}{l}\text { Complete biofuel cell. } \\
\text { Current and voltage } \\
\text { decrease by ca. } 4 \text { and } 8 \% \text {, } \\
\text { respectively, over ca. } 3 \mathrm{~h} \text {, } \\
\text { mainly due to depletion of } \\
\text { fuel and oxidiser substrates }\end{array}$ & Katz et al. (1999a) \\
\hline $\begin{array}{l}\text { MET glucose/MET } \\
\mathrm{O}_{2}\end{array}$ & GOx/COx & $\begin{array}{l}\text { Apo-GOx reconstituted on } \\
\text { PQQ-FAD monolayer } \\
\text { associated with gold anode } \\
(0.8), \text { COx affinity complexed } \\
\text { with Cyt. } c \text { on a maleimide } \\
\text { monolayer, and crosslinked } \\
\text { with glutaric dialdehyde on } \\
\text { gold cathode }(0.8)\end{array}$ & 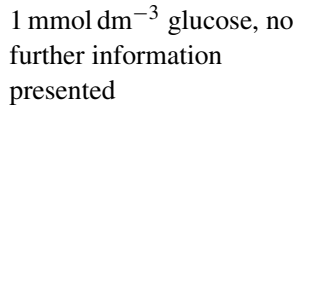 & 0.112 & 0.115 & $\begin{array}{l}5 \text { (at } 0.9 \mathrm{k}( \\
\text { external load) }\end{array}$ & $\begin{array}{l}\text { Non-compartmentalised, } \\
\text { complete biofuel cell. Thin } \\
\text { layer cell with } 5 \mathrm{~mm} \\
\text { electrode separation. Stable } \\
\text { (no potential or current } \\
\text { variation) over } 48 \mathrm{~h} \text { with } \\
\text { flowing } 1 \mathrm{mmol} \mathrm{dm}{ }^{-3} \\
\text { glucose }\end{array}$ & Katz et al. (1999c) \\
\hline $\mathrm{H}_{2} / \mathrm{MET} \mathrm{O}_{2}$ & -/laccase & $\begin{array}{l}\text { Platinised platinum gauze } \\
\text { anode (32), either glassy } \\
\text { carbon (4.0) or platinum foil } \\
\text { (2.5) cathode }\end{array}$ & $\begin{array}{l}0.2 \mathrm{~mol} \mathrm{dm}^{-3} \text { acetate } \\
\text { buffer } \mathrm{pH} 4 \text {. Anolyte } \mathrm{H}_{2} \\
\text { saturated. Catholyte also } \\
2 \text { mmol dm } \\
\text { saturated }\end{array}$ & 1 & 0.12 & $\begin{array}{l}42 \text { (at } 0.61 \mathrm{~V} \\
\text { with } 1 \mathrm{k}( \\
\text { external load) }\end{array}$ & $\begin{array}{l}\text { Maximum power density } \\
\text { without laccase and ABTS } \\
\text { present } 15 \mu \mathrm{W} \mathrm{cm}^{-2} \text { at } \\
0.26 \mathrm{~V} \text { or } 2.9 \mu \mathrm{W} \mathrm{cm}^{-2} \text { at } \\
0.28 \mathrm{~V} \text { with Pt or GC } \\
\text { electrodes, respectively }\end{array}$ & Palmore and Kim (1999) \\
\hline
\end{tabular}


MET glucose or
hydrolysed corn

GOx/HRP

syrup/MET

$\mathrm{H}_{2} \mathrm{O}_{2}$

(MET

MET glucose/MET
$\mathrm{O}_{2}$

sGDH/BOx

(also some

notes on GOx

Glassy carbon disc electrodes (0.07). Anode has sGDH (or GOx) with

poly(1-vinylimidazole)

complexed with Os $\left(4,4^{\prime}-\right.$

dimethyl-2,2'-bipyridine) ${ }_{2} \mathrm{Cl}$.

Cathode has BOx with

poly(4-vinylpyridine)

complexed with

$\mathrm{Os}\left(2,2^{\prime} \text {-bipyridine }\right)_{2} \mathrm{Cl}$ and

quaternised with

MET glucose/MET GOx/COx

with Cu-poly (acrylic acid)

anode Apo-GOx

reconstituted on PQQ-FAD

monolayer. Cathode COx

affinity complexed with Cyt.

$c$ on a maleimide monolayer,

and crosslinked with glutaric

dialdehyde bromoethylamine

and functionalised with:
$0.5 \mathrm{~g} \mathrm{dm}^{-3}$ Na-benzoate,

$0.1 \mathrm{~mol} \mathrm{dm}^{-3}$

K-phosphate $\mathrm{pH} 7.0$,

nitrogen purged and

blanketed. Anolyte also

$1 \mathrm{mmol} \mathrm{dm}^{-3}$ glucose or

hydrolysed corn syrup.

Catholyte also

$1 \mathrm{mmol} \mathrm{dm}{ }^{-3} \mathrm{H}_{2} \mathrm{O}_{2}$
$30 \mathrm{mmol} \mathrm{dm}^{-3}$ MOPS buffer $\mathrm{pH} 7.0$,

$3 \mathrm{mmol} \mathrm{dm}^{-3} \mathrm{CaCl}_{2}$ and

$50 \mathrm{mmol} \mathrm{dm}^{-3}$ glucose,

$\mathrm{O}_{2}$ saturated
0.44 (at $25^{\circ} \mathrm{C}$ ) $\quad 0.43$ (under

$80 \mathrm{mmol} \mathrm{dm}^{-3}$ glucose, $0.1 \mathrm{~mol} \mathrm{dm}^{-3}$ Tris buffer, $\mathrm{pH}$ 7.0, air-saturated
0.12

更
stirring)

$\begin{array}{ll}5.94 \times 10^{-3} & 0.15(\text { at } \\ \text { at } 100 \mathrm{k}( & 0.021 \mathrm{~V}) \\ \text { external } & \end{array}$

0.55
Complete biofuel cell.

Data in figures and text do

not agree. Almost stable

power output over 15 days

operating on glucose:

$0.15 \mu \mathrm{W} \mathrm{cm} \mathrm{cm}^{-2}$ at $0.021 \mathrm{~V}$.

(Maximum potential

decreased by $2.32 \%$ over

this period.) Without

halting the system the

feed solution was changed

to hydrolysed corn syrup.

This increased the

potential output by $5.8 \%$,

and exhibited similar

stability over 15 days

58 (at $0.19 \mathrm{~V}$ ) Non-compartmentalised, Tsujimura et al. (2002)

complete biofuel cell.

BOx reaction is the

limiting factor governing

the cell maximum

currents (or output)

4.3 (at $1 \mathrm{k}($
external load)

Non-compartmentalised,

complete biofuel cell.

$\mathrm{Cu}^{2+}$ poly(acrylic acid)

film between the gold

electrode and the

enzyme-contacting layers

could be cycled between

the conducting $\left(\mathrm{Cu}^{0}\right)$ and

non-conducting $\left(\mathrm{Cu}^{2+}\right)$

states by the application

of an external potential,

allowing the cell to be

switched on or off. OCV

declined by $25 \%$ over $3 \mathrm{~h}$

but could be reactivated

by $-0.5 \mathrm{~V}$ (vs. SCE) for

$1000 \mathrm{~s}$

Maximum power loss

Anolyte $\mathrm{pH} 7.15$ buffer,

0.62

3

1160

$6.1 \%$ over 7 days

$\mathrm{CH}_{3} \mathrm{CHO}$ to $\quad$ AldDH, Or poly(methylene green) and

$\mathrm{CH}_{3} \mathrm{COOH}$ or $\mathrm{ADH}+$

TBATFB/Nafion with

$\mathrm{MeOH}$ to $\mathrm{H}_{2} \mathrm{CO}$ formaldehyde enzyme(s) entrapped anode

to $\mathrm{HCOOH}$ to dehydroge- (1), ELAT gas diffusion

$\mathrm{CO}_{2} / \mathrm{O}_{2}$

nase + FDH

cathode with $20 \%$ [1 mg

and $1.0 \mathrm{mmol}^{-3} \mathrm{dm}^{-3}$

0.82

(EtOH or $\mathrm{MeOH})$.

$0.82 \quad 5.2$

Catholyte pH 7.15

phosphate buffer,

AldDH)

2

(EtOH-ADH)

2040

(EtOH-ADH). $\mathrm{MeOH}$ cell

$\mathrm{cm}^{-2}$ ] Pt (area unspecified) saturated with $\mathrm{O}_{2}$
AldDH). 5.0

$(\mathrm{MeOH})$
(EtOH-ADH- suffers no performance

AldDH). 1550 drop in 5 days

$(\mathrm{MeOH})$
Pizzariello et al. (2002) 


\begin{tabular}{|c|c|c|c|c|c|c|c|c|}
\hline $\begin{array}{l}\text { System } \\
\text { (oxidation/reduction) }\end{array}$ & $\begin{array}{l}\text { Bio- } \\
\text { catalyst(s) }\end{array}$ & Electrodes $\left(\operatorname{area} / \mathrm{cm}^{2}\right)$ & Electrolyte & $\mathrm{OCV} / \mathrm{V}$ & $\begin{array}{l}\text { Current } \\
\text { density } \\
\left(\mu \mathrm{Acm}^{-2}\right)\end{array}$ & $\begin{array}{l}\text { Power density } \\
\left(\mu \mathrm{Acm}^{-2}\right)\end{array}$ & Comments & Reference \\
\hline MET glucose $/ \mathrm{O}_{2}$ & GDH/- & $\begin{array}{l}\text { Zinc Chlorin-e }{ }_{6} \text { adsorbed } \\
\text { nano-crystalline titanium } \\
\text { dioxide on optically } \\
\text { transparent conductive glass } \\
\text { plate anode (5). Platinum } \\
\text { coated optically transparent } \\
\text { conductive glass plate } \\
\text { cathode (N/A). }\end{array}$ & $\begin{array}{l}0.1 \mathrm{~mol} \mathrm{dm}^{-3} \text { glucose, } \\
3.5 \mathrm{mmol} \mathrm{dm} \mathrm{NAD}^{-3} \mathrm{NAD}^{+}, \\
100,000 \mathrm{units} \mathrm{dm}^{-3} \mathrm{GDH}, \\
0.1 \mathrm{~mol} \mathrm{dm}^{-3} \mathrm{KCl}, \\
10 \mathrm{mmol} \mathrm{dm}^{-3} \text { potassium } \\
\text { phosphate buffer } \mathrm{pH} 7.0 . \\
\text { Dissolved oxygen used to } \\
\text { fuel platinum cathode }\end{array}$ & 0.44 & $6.8 \times 10^{-3}$ & $16 \times 10^{-3}$ & $\begin{array}{l}\text { Photo-operated cell which } \\
\text { will only oxidise glucose } \\
\text { when illuminated }\end{array}$ & Takeuchi and Amao (2004) \\
\hline \multicolumn{9}{|c|}{ (B) Fuel cell based on the 'two-fibre' design } \\
\hline $\begin{array}{l}\text { MET glucose/MET } \\
\mathrm{O}_{2}\end{array}$ & GOx/laccase & $\begin{array}{l}7 \mathrm{~mm} \text { diameter } 2 \mathrm{~cm} \text { carbon } \\
\text { fibre electrodes }\left(4.4 \times 10^{-3}\right) \text {. } \\
\text { Anode has GOx crosslinked } \\
\text { with poly }\{N \text {-vinyl imidazole } \\
{\left[\mathrm{Os}\left(4,4^{\prime}-\text { dimethyl- } 2,2^{\prime}-\right.\right.} \\
\left.\text { bipyridine })_{2} \mathrm{Cl}\right]^{+/ 2+}-\text { co- } \\
\text { acrylamide }\} \text {, cathode has } \\
\text { laccase and } \\
\text { poly }(N \text {-vinyl-imidazole }) \text { with } \\
\text { one fifth of the rings } \\
\text { complexed with }\left[\text { Os }\left(4,4^{\prime}-\right.\right. \\
\text { dimethyl-2, } \\
\left(2,2^{\prime}, 6^{\prime}, 2^{\prime \prime} \text {-terpyripyidine }\right)\end{array}$ & $\begin{array}{l}15 \mathrm{mmol} \mathrm{dm}^{-3} \text { glucose, } \\
0.2 \mathrm{~mol} \mathrm{dm}^{-3} \text { citrate } \\
\text { buffer } \mathrm{pH} 5.0, \text { aerated }\end{array}$ & 0.8 & 0.46 & $\begin{array}{l}64\left(\text { at } 23^{\circ} \mathrm{C}\right) \text {, } \\
137\left(\text { at } 37^{\circ} \mathrm{C}\right) \\
\text { both at } 0.4 \mathrm{~V}\end{array}$ & $\begin{array}{l}\text { Non-compartmentalised, } \\
\text { complete biofuel cell. } \\
\text { Carbon fibres ca. } 0.8 \mathrm{~mm} \\
\text { apart. }<10 \% \text { power loss } \\
\text { over } 24 \mathrm{~h}, \mathrm{ca} .25 \% \text { power } \\
\text { loss over } 72 \mathrm{~h} \text { continuous } \\
\text { operation }\end{array}$ & Chen et al. (2001) \\
\hline $\begin{array}{l}\text { MET glucose/MET } \\
\mathrm{O}_{2}\end{array}$ & GOx/BOx & $\begin{array}{l}7 \mathrm{~mm} \text { diameter } 2 \mathrm{~cm} \text { carbon } \\
\text { fibre electrodes }\left(4.4 \times 10^{-3}\right) \text {. } \\
\text { Anode has GOx with redox } \\
\text { polymer containing } \\
{\left[\mathrm{Os}\left(N, N^{\prime} \text {-dialkylated- } 2,2^{\prime}-\right.\right.} \\
\left.\text { bis-imidazole })_{3}\right]^{2+/ 3+} \text { centres. } \\
\text { Cathode has BOx with redox } \\
\text { copolymer of polyacrylamide } \\
\text { and poly }(N \text {-vinyl-imidazole }) \\
\text { complexed with } \\
{\left[\text { Os }\left(4,4^{\prime} \text {-dichloro-2,2'- }\right.\right.} \\
\left.\text { bipyridine })_{2} \mathrm{Cl}_{2}\right]^{+/ 2+}\end{array}$ & $\begin{array}{l}15 \mathrm{mmol} \mathrm{dm}^{-3} \text { glucose, } \\
0.14 \mathrm{~mol} \mathrm{dm}^{-3} \mathrm{NaCl}, \\
20 \mathrm{mmol} \mathrm{dm}^{-3} \text { phosphate, } \\
\text { pH 7.2, aerated }\end{array}$ & 0.84 & 0.85 & $\begin{array}{l}432\left(\text { at } 37^{\circ} \mathrm{C},\right. \\
0.52 \mathrm{~V})\end{array}$ & $\begin{array}{l}\text { Non-compartmentalised, } \\
\text { complete biofuel cell. } \\
\text { When operating } \\
\text { continuously for a week } \\
\text { the power output declines } \\
\text { from } 1.9 \text { to } 1.0 \mu \mathrm{W} \text { at } \\
0.52 \mathrm{~V}\end{array}$ & Mano et al. (2002c) \\
\hline $\begin{array}{l}\text { MET glucose/MET } \\
\mathrm{O}_{2}\end{array}$ & GOx/BOx & $\begin{array}{l}7 \mathrm{~mm} \text { diameter } 2 \mathrm{~cm} \text { carbon } \\
\text { fibre electrodes }\left(4.4 \times 10^{-3}\right) \text {. } \\
\text { Anode has GOx with redox } \\
\text { polymer } \\
\mathrm{PVI}-\left[\mathrm{Os}\left(4,4^{\prime}-\text { diamino- } 2,2^{\prime}-\right.\right. \\
\left.\text { bipyridine })_{2} \mathrm{Cl}\right]^{+/ 2+} \text {. Cathode } \\
\text { has BOx with redox } \\
\text { copolymer of polyacrylamide } \\
\text { and poly }(N \text {-vinyl-imidazole }) \\
\text { complexed with } \\
{\left[\mathrm{Os}\left(4,4^{\prime}-\text {-dichloro- } 2,2^{\prime}-\right.\right.} \\
\left.\text { bipyridine })_{2} \mathrm{Cl}_{2}\right]^{+/ 2+}\end{array}$ & $\begin{array}{l}15 \mathrm{mmol} \mathrm{dm}^{-3} \text { glucose, } \\
20 \mathrm{mmol} \mathrm{dm}^{-3} \\
\text { phosphate, } \mathrm{pH} 7.4 \\
0.14 \mathrm{~mol} \mathrm{dm}^{-3} \mathrm{NaCl}\end{array}$ & 0.68 & $\begin{array}{l}0.2 \text { (limited by } \\
\text { glucose } \\
\text { electro- } \\
\text { oxidation } \\
\text { rate) }\end{array}$ & $\begin{array}{l}50(\text { at } 0.5 \mathrm{~V} \\
\left.\text { and } 37.5^{\circ} \mathrm{C}\right) \\
10(\text { at } 0.5 \mathrm{~V} \\
\left.\text { and } 23^{\circ} \mathrm{C}\right)\end{array}$ & $\begin{array}{l}\text { Non-compartmentalised, } \\
\text { complete biofuel cell. } \\
\text { After } 2 \text { days of operation } \\
\text { the power density dropped } \\
\text { from } 50 \text { to } 30 \mu \mathrm{W} \mathrm{cm}{ }^{-2}\end{array}$ & Kim et al. (2003b) \\
\hline
\end{tabular}




\begin{tabular}{|c|c|c|c|c|c|c|c|c|}
\hline $\begin{array}{l}\text { MET glucose (or } \\
\text { plant } \\
\text { sugars)/MET } \mathrm{O}_{2}\end{array}$ & GOx/BOx & $\begin{array}{l}7 \mu \mathrm{m} \text { diameter } 2 \mathrm{~cm} \text { carbon } \\
\text { fibre electrodes }\left(4.4 \times 10^{-3}\right) \text {. } \\
\text { Anode has GOx with redox } \\
\text { polymer } \\
\left(\mathrm{PVP}-\left[\mathrm{Os}\left(N, N^{\prime} \text {-dialkylated- }\right.\right.\right. \\
\left.\left.\left.2,2^{\prime} \text {-bisimidazole }\right)_{3}\right]^{2+/ 3+}\right) \text {. } \\
\text { Cathode has BOx with redox } \\
\text { polymer(PAA-PVI-[Os }\left(4,4^{\prime}-\right. \\
\text { dichloro-2,2'- } \\
\left.\left.\text { bipyridine }{ }_{2} \mathrm{Cl}\right]^{+/ 2+}\right)\end{array}$ & $\begin{array}{l}15 \mathrm{mmol} \mathrm{dm}^{-3} \text { glucose, } \\
20 \mathrm{mmol} \mathrm{dm} \text { phosphate, }^{-3} \text { pH } 7.4,0.14 \text { mol dm}^{-3} \\
\text { NaCl Or implantation into } \\
\text { a grape, pH 5.4, } \\
>30 \mathrm{mmol} \mathrm{dm}^{-3} \text { glucose }\end{array}$ & 0.8 & 0.1 & $\begin{array}{l}440 \text { (at } 0.52 \mathrm{~V} \text {, } \\
\text { under air at } \\
37^{\circ} \mathrm{C} \text { ) }\end{array}$ & $\begin{array}{l}\text { Non-compartmentalised, } \\
\text { complete biofuel cell. } \\
\text { When implanted in a } \\
\text { grape the maximum } \\
\text { power density was } \\
240 \mu \mathrm{W} \mathrm{cm}{ }^{-2} \text { with the } \\
\text { cathode fibre near the skin } \\
\text { of the grape (oxygen } \\
\text { supply was limiting), and } \\
78 \% \text { of initial power } \\
\text { output remained after } 24 \mathrm{~h} \\
\text { operation }\end{array}$ & Mano et al. (2003a) \\
\hline $\begin{array}{l}\text { MET glucose/MET } \\
\mathrm{O}_{2}\end{array}$ & GOx/BOx & $\begin{array}{l}7 \mu \mathrm{m} \text { diameter } 2 \mathrm{~cm} \text { carbon } \\
\text { fibre electrodes }\left(4.4 \times 10^{-3}\right) \text {. } \\
\text { Anode has GOx with redox } \\
\text { polymer } \\
\left(\text { PVP-[Os }\left(4,4^{\prime} \text {-dimethoxy- }\right.\right. \\
\left.\left.\left.2,2^{\prime} \text {-bipyridine }\right)_{2} \mathrm{Cl}\right]^{+/ 2+}\right) \text {. } \\
\text { Cathode has BOx with redox } \\
\text { polymer(PAA-PVI-[Os }\left(4,4^{\prime}-\right. \\
\text { dichloro- } 2,2^{\prime}- \\
\left.\text { bipyridine }{ }_{2} \mathrm{Cl}\right]^{+/ 2+} \text { ) }\end{array}$ & $\begin{array}{l}15 \mathrm{mmol} \mathrm{dm}^{-3} \text { glucose, } \\
20 \mathrm{mmol} \mathrm{dm}^{-3} \\
\text { phosphate, } \mathrm{pH} 7.4, \\
0.14 \mathrm{~mol} \mathrm{dm}^{-3} \mathrm{NaCl}\end{array}$ & 0.63 & 0.8 & $\begin{array}{l}244 \text { (at } 0.36 \mathrm{~V} \text {, } \\
\text { under air at } \\
37.5^{\circ} \mathrm{C} \text { ) }\end{array}$ & $\begin{array}{l}\text { Non-compartmentalised, } \\
\text { complete biofuel cell. } \\
\text { Power density limited by } \\
\text { glucose oxidation } \\
\text { electrocatalysis rate. } \\
\text { Stability not investigated }\end{array}$ & Mano and Heller (2003) \\
\hline $\begin{array}{l}\text { MET glucose/MET } \\
\mathrm{O}_{2}\end{array}$ & GOx/laccase & $\begin{array}{l}7 \mu \mathrm{m} \text { diameter } 2 \mathrm{~cm} \text { carbon } \\
\text { fibre electrodes }\left(4.4 \times 10^{-3}\right) \text {. } \\
\text { Anode has GOx with redox } \\
\text { polymer } \\
\left(\mathrm{PVI}-\left[\mathrm{Os}\left(N, N^{\prime} \text {-dialkylated- }\right.\right.\right. \\
\left.\left.\left.2,2^{\prime} \text {-bisimidazole }\right)_{3}\right]^{2+/ 3+}\right) \text {. } \\
\text { Cathode has BOx with redox } \\
\text { polymer }\left(\mathrm{PVI}-\left[\mathrm{Os}\left(2,2^{\prime}, 6^{\prime}, 2^{\prime \prime}-\right.\right.\right. \\
\text { terpyridine- } 4,4^{\prime} \text {-dimethyl- } \\
\left.\left.\left.2,2^{\prime} \text {-bipyridine }\right)_{2} \mathrm{Cl}\right]^{+/ 2+}\right)\end{array}$ & $\begin{array}{l}15 \mathrm{mmol} \mathrm{dm}^{-3} \text { glucose, } \\
20 \mathrm{mmol} \mathrm{dm}^{-3} \text { citrate } \mathrm{pH} \\
5.0 \text { under air, } 37^{\circ} \mathrm{C}\end{array}$ & 1.0 & 0.36 & $\begin{array}{l}268 \text { (at } 0.78 \mathrm{~V} \text {, } \\
\text { under air at } \\
37^{\circ} \mathrm{C} \text { ) }\end{array}$ & $\begin{array}{l}\text { Non-compartmentalised, } \\
\text { complete biofuel cell. } \\
\text { When operated } \\
\text { continuously for a week it } \\
\text { lost ca. } 10 \% \text { of its power } \\
\text { per day }\end{array}$ & Mano et al. (2003b) \\
\hline MET glucose $/ \mathrm{O}_{2}$ & GOx/laccase & 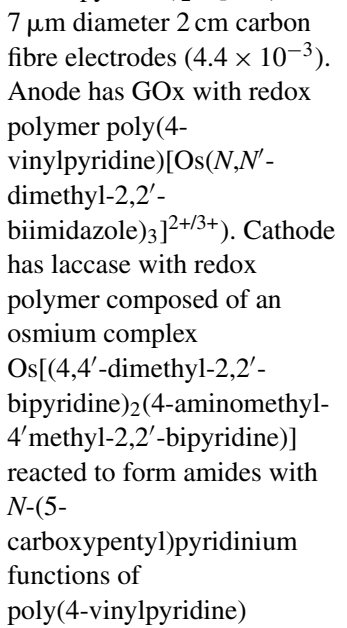 & $\begin{array}{l}0.1 \mathrm{~mol} \mathrm{dm} \mathrm{dm}^{-3} \mathrm{pH} \text { citrate } \\
\text { buffer, } 15 \mathrm{mmol} \mathrm{dm}^{-3} \\
\text { glucose under air at } 37^{\circ} \mathrm{C}\end{array}$ & 1.0 & 0.45 & 350 & $\begin{array}{l}\text { Non-compartmentalised, } \\
\text { complete biofuel cell. } \\
\text { Stability not tested. } \\
\text { Overpotential for oxygen } \\
\text { reduction in these } \\
\text { conditions is lower than } \\
\text { that for platinum }\end{array}$ & Heller (2004) \\
\hline
\end{tabular}

440 (at $0.52 \mathrm{~V}, \quad$ Non-compartmentalised, Mano et al. (2003a) under air at complete biofuel cell. $\mu \mathrm{W} \mathrm{cm}^{-2}$ with the de fibre near the ski the grape (oxygen $78 \%$ of initial power output remained after 24 
a conventional hydrogen-oxygen platinum catalysed fuel cell. The authors are not aware of any attempt made to include this system in an integrated fuel cell (i.e. with the enzymes and the electrodes in the same compartment).

\subsection{Enzyme electrodes: the common challenges in DET and MET enzymatic biofuel cells}

For convenience in discussing methods of establishing electron transfer between enzymes and electrodes (Heller, 1992) divided redox enzymes into three groups. The differences between the groups are not absolutely defined, but they provide a framework for considering the different problems with using different enzymes (Fig. 7).

The first group has enzymes with nicotinamide adenine dinucleotide (NADH/NAD ${ }^{+}$) or nicotinamide adenine dinucleotide phosphate $\left(\mathrm{NADPH} / \mathrm{NADP}^{+}\right)$redox centres, which are often weakly bound to the protein of the enzyme. The weak binding allows the redox centres to diffuse away from the enzyme, acting as carriers of electrons - one of their natural functions is cellular electron transfer. In biofuel cell systems this allows the cofactor to also function as a natural redox mediator. There are three problems that must be solved in using a NADH/NAD ${ }^{+}$ or $\mathrm{NADPH} / \mathrm{NADP}^{+}$system. Firstly, the electrodes must be designed for two-electron transfer so that the reaction can com- plete, i.e. any free radical produced by the transfer of a single electron must be stabilised by the transfer of a second electron before it can irreversibly react. Secondly, the NADH/NAD ${ }^{+}$ or $\mathrm{NADPH} / \mathrm{NADP}^{+}$must be prevented from diffusing away from the enzymes and electrode. Thirdly, $\mathrm{NADH} / \mathrm{NAD}^{+}$or $\mathrm{NADPH} / \mathrm{NADP}^{+}$must not be hydrolysed at a rapid rate. Additionally, there may be another condition that the overpotential for the two-electron-transfer reaction at the electrode must be small enough not to cause side reactions.

In the second group of enzymes at least part of the redox centre is conveniently located at or near the periphery of the protein shell (e.g. peroxidases). These enzymes are 'designed' to transfer or accept electrons on contact and are thus able to communicate directly with electrodes. The key challenge with this type of enzyme is of orienting the enzyme on the electrode for maximum activity, both for rapid electron transfer and also for diffusional access of the substrate to the enzyme.

The third model type of enzyme is the enzyme with a strongly bound redox centre deeply bound in a protein or glycoprotein shell. This type of enzyme neither communicates readily with electrodes, nor releases the active centre to act as an electron shuttle. If direct communication via adsorption on an electrode is attempted the potentials required to oxidise or reduce the active centre destroy the enzyme, and the rate of electron transfer unaided by these large potentials is negligibly

(A)
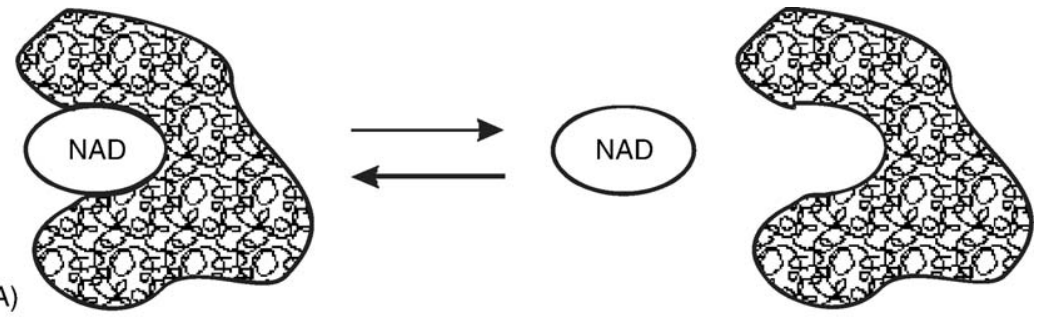

(B)
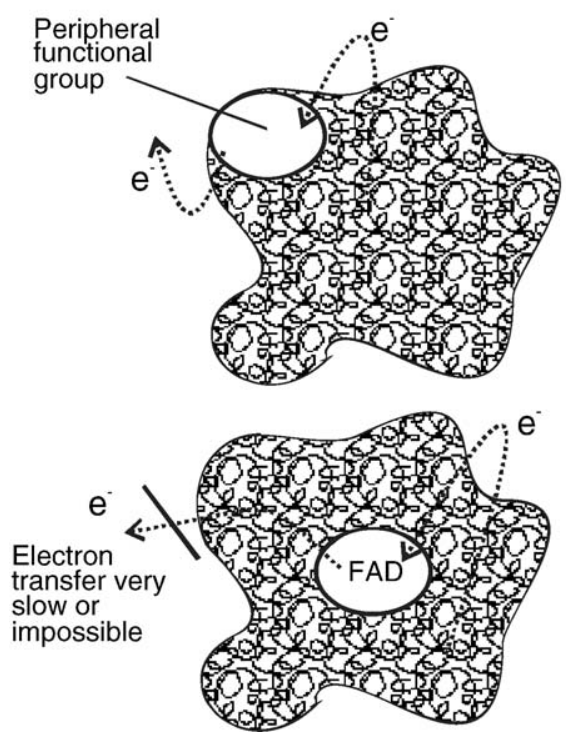

(C)

Fig. 7. The different locations of enzyme active centres, and how they effect electron transfer in unmodified enzymes. (A) Enzyme active centre is NAD(H) or $\mathrm{NADP}(\mathrm{H})$. The active centre can diffuse out of the enzyme and travel to the electrode, transferring electrons itself. (B) The active centre (often porphyrin derivatives) is located on the periphery of the enzyme, and can transfer electrons directly to (or receive electrons from) an electrode. (C) The enzyme has strongly bound redox centres, surrounded by the glycoprotein shell. Direct electron transfer from the active centre is either extremely slow or impossible, requiring the use of mediator molecules capable of penetrating into the enzyme to transport charge. 
slow compared with the turnover rate of the enzyme. Glucose oxidase (GOx), by far the most studied biosensor and fuel cell enzyme, is an example of this type of enzyme, having a strongly bound FAD active centre.

\subsection{Diffusive MET enzymatic electrodes}

This class of enzymatic biofuel cell system relies on some sort of mediator to transfer electrons from the site of the fuel oxidation at the enzyme to the electrode surface. The mediator is regenerated at the electrode surface and circulates continuously between the enzyme and the electrode. Of the models of redox enzymes in the group above, mediated electron transfer applies to most systems involving weakly bound NADH or NADPH active centres diffusing to the electrode, and also led to much early research using enzymes with strongly bound redox centres. In the former case the active centre would diffuse, in the latter an artificial mediator molecule would shuttle between the enzyme and the electrode.

Palmore et al. (1998) demonstrated a multi-enzyme fuel cell oxidising methanol to carbon dioxide and water. The successive steps of methanol oxidation were performed by alcohol$(\mathrm{ADH})$, aldehyde- (AldDH), and formate- (FDH) dehydrogenases, dependent upon $\mathrm{NAD}^{+}$reduction. A fourth enzyme, diaphorase regenerated the $\mathrm{NAD}^{+}$, reducing benzylviologen $\left(1,1^{\prime}\right.$-dibenzyl-4,4'-bipyridinium dichloride, $\left.\mathrm{BV}^{+/ 2+}\right)$. The benzylviologen was oxidised at a graphite plate anode $\left(2 \mathrm{~cm}^{2}\right.$ area) to complete the electron transfer half-reaction. The cathode used was an oxygen-reducing Pt-gauze. The completed cell was limited by the NADH to $\mathrm{NAD}^{+}$oxidation reaction, and associated reduction of $\mathrm{BV}^{2+}$ to $\mathrm{BV}^{+}$at the enzyme concentrations used in the experiments. The power produced by the cell decreased over time as concentration polarisation occurred at the anode as $\mathrm{BV}^{+}$was depleted. Over $8 \mathrm{~h}$ the voltage of the biofuel cell could be repeatedly returned to open circuit values when the load was removed, indicating continuous biocatalytic $\mathrm{BV}^{+}$production. This cell produced open circuit voltage of $0.8 \mathrm{~V}$ and $0.68 \mathrm{~mW} \mathrm{~cm}^{-2}$ at $0.49 \mathrm{~V}$ maximum power density. The stability and lifetime of the fuel cell were not reported outside of the context of needing periodic load removal to maintain current values. The multiple enzyme system used in this case offers a chance to completely oxidise a substrate but at the cost of greater complexity. This makes a structured system based on this chemistry harder to design as provision for intermediate products diffusing between enzymes must be made.

A biofuel cell functionalising electrodes with catalytic monolayers for use with oxidoreductase enzymes in each compartment was demonstrated by Willner et al. (1998a). This system covalently bound pyrolloquinoline quinone (PQQ) onto a gold anode and microperoxidase-11 (MP-11) onto a gold cathode, in both cases using self-assembled monolayers (SAM) of cystamine. The PQQ modified anode would two-electron oxidise $\mathrm{NADH}$ and $\mathrm{NADPH}$ to $\mathrm{NAD}(\mathrm{P})^{+}$, particularly in the presence of $\mathrm{Ca}^{2+}$ ions, making it suitable as a catalytic electrode surface to be paired with an oxidase that reduces $\mathrm{NAD}(\mathrm{P})^{+}$as its electron acceptor. The MP-11 modified cathode reduced hydrogen peroxide to water, allowing it to generate power from peroxide produced from the action of a flavo-oxido-reductase. The open circuit voltage of the cell was approximately $0.3 \mathrm{~V}$. With the substrates (NADH and $\mathrm{H}_{2} \mathrm{O}_{2}$ ) in slight excess of the saturation levels the maximum power load obtained from the fuel cell was $8 \mu \mathrm{W}$ at an external load of $3 \mathrm{k} \Omega$, equivalent to $40 \mu \mathrm{W} \mathrm{cm}{ }^{-2}$ of electrode, roughness factor ca. 15. Although the system used in this cell is a direct system, with catalyst (PQQ, anode) and enzyme (MP-11, cathode) bound to the electrodes it is intended for use as the base in an indirect scheme where other enzymes generate the NADH and the $\mathrm{H}_{2} \mathrm{O}_{2}$ that these electrodes utilise. Due to the expense of NADH, a system relying on the addition of NADH as fuel would be overly expensive, and thus a mechanism for retaining the $\mathrm{NAD}(\mathrm{H})$ within the system would be required. No stability information for these modified electrodes is provided in the paper.

Palmore and Kim (1999) investigated the cathodic reduction of oxygen to water by the enzyme laccase in free solution, mediated by 2,2'-azinobis(3-ethylbenzothiazoline-6sulphonate) (ABTS) at platinum and glassy carbon cathodes. A platinised platinum gauze hydrogen anode was used in the fuel cell design. The standard electrolyte in each compartment was a $0.2 \mathrm{~mol} \mathrm{dm}^{-3}$ acetate buffer, adjusted to $\mathrm{pH} 4.0$. The catholyte also contained laccase and $2 \times 10^{-3} \mathrm{~mol} \mathrm{dm}^{-3}$ ABTS. It was found that laccase was most effective when used in a $0.2 \mathrm{~mol} \mathrm{dm}^{-3}$ citrate-phosphate buffer adjusted to $\mathrm{pH} 3$ $\left(40 \mathrm{mU} \mathrm{mg}^{-1}\right)$. The cathode performance was assessed with $10 \mathrm{mg}$ laccase (activity ca. $35 \mathrm{mU} \mathrm{mg}^{-1}$ ). The maximum power density achieved with the biocathode was $42 \mu \mathrm{W} \mathrm{cm}{ }^{-2}$ at $0.61 \mathrm{~V}$ $(R=1 \mathrm{k} \Omega)$. When oxygen was reduced to water at platinum or glassy carbon in these conditions without the presence of laccase and ABTS the maximum power densities were $15 \mu \mathrm{W} \mathrm{cm}{ }^{-2}$ at $0.26 \mathrm{~V}$ and $2.9 \mu \mathrm{W} \mathrm{cm}{ }^{-2}$ at $0.28 \mathrm{~V}$, respectively (Fig. 8).

Recently a method for producing an alcohol dehydrogenase $(\mathrm{ADH})$ based biofuel cell in a novel membrane electrode assembly (MEA) configuration has been described (Akers et al., 2005). This is an important step for the use of biofuel cells in a wider commercial environment as the MEA represents a highly efficient fuel cell configuration with almost zero gap between the electrodes, and is a popular design for inorganic fuel cells for the automotive industry. The enzymes used were $\mathrm{NAD}^{+}$ dependant, so the expanded graphite electrode was pre-treated with methylene green, electropolymerised to poly(methylene green) as an $\mathrm{NAD}^{+}$oxidation electrocatalyst. The enzyme was contained in a quaternary ammonium salt-modified Nafion membrane coated onto the electrode. The modification of the membrane neutralised its acidity and increased the pore size so that it not only retained the enzyme, but also reduced the inactivation rate, prolonging the enzyme lifetime to 60-90 days (Akers and Minteer, 2003). Alcohol dehydrogenase and a combination of alcohol and aldehyde dehydrogenase (AldDH) were utilised with ethanol as the fuel, and for comparison with the cell of Palmore (Palmore et al., 1998) a methanol oxidising cell was constructed using alcohol-, formaldehydeand formate-dehydrogenases (FDH) (Eqs. (13)-(15)). The MEA based cell methanol achieved $1.55 \mathrm{~mW} \mathrm{~cm}^{-2}$ and open circuit potential $0.71 \mathrm{~V}-$ a slightly lower open circuit potential than Palmore et al.'s cell, but over double their power density. 


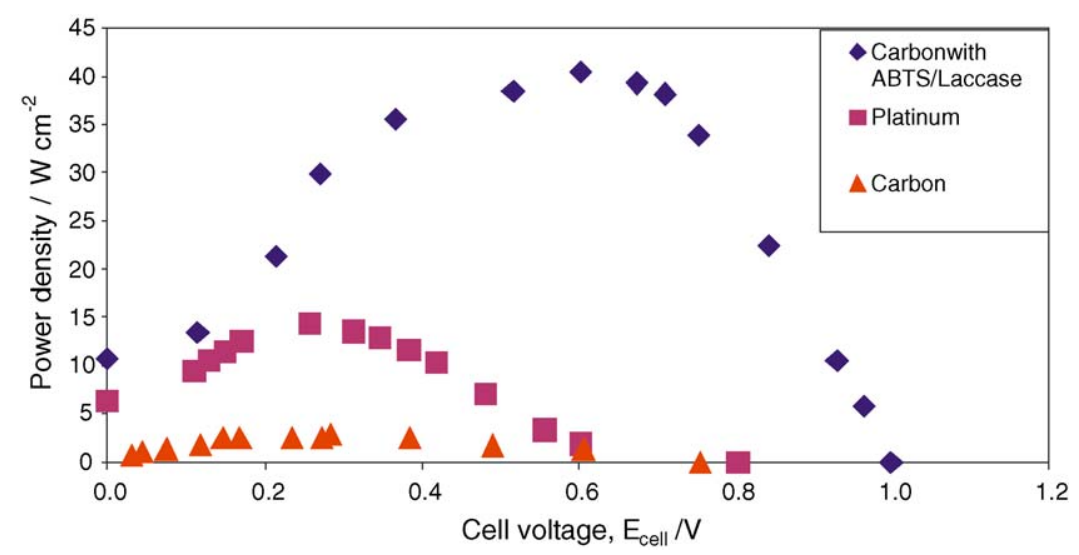

Fig. 8. Power density of a prototype enzymatic biofuel cell plotted against cell potential to illustrate the cell voltage at which the power density reaches a maximum for different cathodes, and dramatically illustrating the enhancement possible through the use of enzymatic catalysis (after Palmore and Kim, 1999).

\subsection{Non-diffusive enzyme electrodes}

In a non-diffusive enzyme electrode electrons are passed without molecular diffusion from the active site of the enzyme to the electrode and external circuit. In the case of some enzymes (such as peroxidases) DET can be achieved by placing them in contact with the electrode so electrons can conduct through the peripheral redox centres. More usually the enzymes in question are of the third type with strongly bound redox centres, and the techniques used have evolved from attempting connection by simple adsorption (DET) (Bianco et al., 1990), through entrapment in conductive polymers (Gregg and Heller, 1991a,b), to methods connecting the active centre either through a defined structured path (Katz et al., 2001, 1999a,b,c; Katz and Willner, 2003; Willner et al., 1996, 1997, 1998a,b; Zayats et al., 2002b) or a highly conductive redox group-modified polymer electrostatically retaining the enzyme, and latterly with partially mobile redox groups able to penetrate to the active centre(s) (Barton et al., 2002; Chen et al., 2001; Kim et al., 2003b; Mano and Heller, 2003; Mano et al., 2002a,b,c, 2003a,b; Mao et al., 2003; Tsujimura et al., 2002, 2003) (all non-diffusive MET).

Willner et al. (1998b) produced a fuel cell using enzymes for both anode and cathode reactions that had defined communication pathways between the enzyme active centres and the gold electrodes. The anodic reaction was glucose oxidation to gluconic acid by glucose oxidase (reactions (25)-(27)), and the cathodic reaction was reduction of hydrogen peroxide by microperoxidase- 11 .

Electrode-PQQ-FAD-GOx + Glucose

$\rightarrow$ Electrode-PQQ-FADH ${ }_{2}-\mathrm{GOx}+$ Gluconic_acid

$$
\begin{aligned}
& \text { Electrode-PQQ-FADH }{ }_{2}-\mathrm{GOx} \\
& \quad \rightarrow \text { Electrode-PQQH }{ }_{2}-\mathrm{FAD}-\mathrm{GOx}
\end{aligned}
$$

\section{Electrode- $\mathrm{PQQH} \mathrm{H}_{2}-\mathrm{FAD}-\mathrm{GOx}$}

$$
\rightarrow \text { Electrode-PQQ-FAD-GOx }+2 \mathrm{H}^{+}+2 \mathrm{e}^{-}
$$

The anode was assembled by reconstitution of apo-glucose oxidase (glucose oxidase with the FAD active centre removed) onto a monolayer of pyrroloquinoline quinone (PQQ) and flavin adenine dinucleotide phosphate (FAD) associated with a rough gold electrode. The PQQ-FAD monolayer is associated with a rough gold electrode by coupling to a cystamine monolayer (Willner et al., 1996). The MP-11 electrode is constructed more simply as the enzyme is an oligopeptide obtained from controlled hydrolytic digestion of cytochrome $c$ (Cyt $c$ ), and thus consists only of the active site microenvironment and can communicate directly with the electrode.

It is estimated that the glucose oxidase monolayer reconstituted in this manner operates at a turnover rate of electron transfer exceeding that of native GOx with dioxygen as the electron acceptor. The open circuit voltage of the cell was ca. $310 \mathrm{mV}$. The maximum power density obtained from the cell was ca. $160 \mu \mathrm{W} \mathrm{cm}{ }^{-2}$ (geometric area $0.2 \mathrm{~cm}^{2}$ and roughness factor ca. 15) at $3 \mathrm{k} \Omega$ external load. The output from the biofuel cell was identical under Ar and air, as a result of the effective electrical contact of the aligned GOx with the electrode. The power of the fuel cell decreased by $50 \%$ after ca. $3 \mathrm{~h}$ of operation (current dropped but cell voltage remained stable). As the cell was not of a flow construction, part of the current loss was explained by an estimate that $25 \%$ of the available substrate had been consumed, and hence $25 \%$ of the current loss was due to this factor. The remaining decrease in the current was not further explored, so it is unknown whether it was due to inactivation of the enzyme, formation of a fouling layer on the electrode surface or another cause.

The biofuel cell design based on the use of reconstituted glucose oxidase oriented on the anode was developed further (Katz et al., 1999c), replacing the MP-11 based cathode reaction with one based on tethered (site specific coupling of cytochrome $c$ to a maleimide monolayer), ordered (affinity complex) and crosslinking stabilised (crosslinking by glutaric dialdehyde) cytochrome c/cytochrome oxidase (COx) complexes (Fig. 9). This cathode construction reduces dioxygen to water and therefore avoids the need to have hydrogen peroxide as a cathodic 


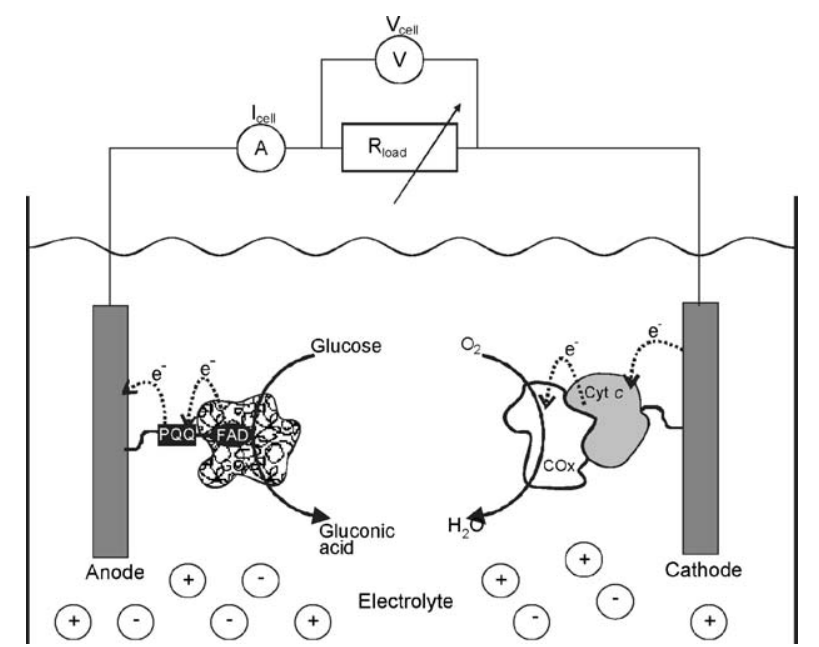

Fig. 9. Schematic diagram showing configuration of a single compartment biofuel cell employing glucose and $\mathrm{O}_{2}$ as fuel and oxidiser, respectively. Structured electron transfer on the PQQ-FAD $\mid$ Gox anode and Cyt. $c \mid$ COx cathode is clearly indicated (after Katz et al., 2003).

reactant. The alignment of the glucose oxidase and high electron transfer turnover rate make the anode insensitive to the presence of oxygen, and the biofuel cell can therefore operate in one compartment. As with the previously listed paper (Willner et al., 1998b) the reconstituted GOx anode operates at a electron transfer turnover rate exceeding that of native GOx with molecular oxygen (the native electron acceptor). The biocathode shifted the reduction of oxygen from ca. $-0.3 \mathrm{~V}$ versus SCE to ca. $0.0 \mathrm{~V}$ versus SCE, indicating that despite the introduction of two proteins associated with the electrode the electrochemical reduction of $\mathrm{O}_{2}$ was facilitated. The maximum power derived from this cell with the electrodes assembled into a thin-layer electrochemical cell with $5 \mathrm{~mm}$ between the electrodes was $4 \mu \mathrm{W}$ at an external load of $0.9 \mathrm{k} \Omega$, equivalent to $5 \mu \mathrm{W} \mathrm{cm} \mathrm{cm}^{-2}$. The open circuit voltage obtained was ca. $110 \mathrm{mV}$. A current/voltage curve for the fuel cell indicated a region of low resistance attributed to ohmic cell-resistance, and a region of high resistance at high current values attributed to interfacial electron transfer resistance at the cathode. The electron transfer resistance between cytochrome $c$ and the electrode is believed to be the rate-limiting factor in this fuel cell design. In a flow system that maintained glucose concentration at $1 \mathrm{mmol} \mathrm{dm}^{-3}$ (the potential of the GOx anode saturates at this concentration) and with air-saturated electrolyte solution the cell performance remained constant over $48 \mathrm{~h}$. The lifetime of the cell beyond this was not reported.

Another variation on the GOx/MP-11 system was to produce a biofuel cell based on a two phase separation of anolyte and catholyte (Katz et al., 1999a). The same gold-PQQ-GOx anode system was used in $0.01 \mathrm{~mol} \mathrm{dm}^{-3}$ phosphate buffer $\mathrm{pH} 7.0$ oxidising $1 \mathrm{mmol} \mathrm{dm}^{-3}$ glucose formed an aqueous upper layer. The catholyte was an organic phase of dichloromethane containing tetrabutylammonium tetrafluoroborate (TBATFB) supporting electrolyte, using an MP-11 modified gold cathode to reduce $1 \mathrm{mmol} \mathrm{dm}{ }^{-3}$ cumene peroxide to cumene alcohol, although the two phase system can use the cathode to reduce any hydroperoxide so long as it is soluble only in the organic oil phase. This fuel cell system had an open circuit voltage of $1 \mathrm{~V}$ and a short circuit current density of $0.83 \mathrm{~mA} \mathrm{~cm}^{-2}$. The maximum power produced was $520 \mu \mathrm{W}$ (ca. $4.1 \mathrm{~mW} \mathrm{~cm}^{-2}$ ) at $0.46 \mathrm{~V}$ with an external resistance of $0.4 \mathrm{k} \Omega$.

In a $3 \mathrm{~h}$ stability test the voltage and current decrease by ca. 4 and $8 \%$, respectively, after $3 \mathrm{~h}$ of operation, attributed 'mainly' to substrate depletion. The authors concluded that this demonstrates that the system had 'quite good' stability, but this conclusion would appear to be premature based on such a short test under conditions where the substrate depletes.

Katz and Willner (2003) have recently reported a biofuel cell system based on the PQQ-FAD-reconstituted GOx wiring method that can be electronically activated or disabled. This was achieved by using a $\mathrm{Cu}^{2+}$-poly(acrylic acid) film on a glass supported $50 \mathrm{~nm}$ thick polycrystalline Au electrode as the base onto which the PQQ, FAD and GOx layers were subsequently assembled. The same base was used to assemble the previously described cytochrome $c /$ cytochrome oxidase electrode for an oxygen-reducing cathode. By applying a potential of $-0.5 \mathrm{~V}$ versus SCE the $\mathrm{Cu}^{2+}$-poly(acrylic acid) film can be reduced to $\mathrm{Cu}^{0}$-poly(acrylic acid) that electrically contacts the bioreactive part of the electrode. The reduced film can be reoxidised to the non-conductive $\mathrm{Cu}^{2+}$ state by the application of a potential of $0.5 \mathrm{~V}$. This reversibility allows the biofuel cell system to be cycled between a conductive and non-conductive state. Reduction of the $\mathrm{Cu}^{2+}$ is a slow process involving the migration of the ions through the film to conductive sites (taking ca. $1000 \mathrm{~s}$ ). Therefore, varying the duration of the reducing potential allows the degree of conductivity of the film to be controlled, and hence the output power of the biofuel cell can be tuned.

The biofuel cell system produced by this method had a short circuit current of $550 \mu \mathrm{A} \mathrm{cm}^{-2}$ in the 'on' state $\left(\mathrm{Cu}^{0}\right.$ poly(acrylic acid)) and $0 \mu \mathrm{A} \mathrm{cm}^{-2}$ in the 'off' state, and open circuit voltage $120 \mathrm{mV}$ and $0 \mathrm{mV}$ in the 'on' and 'off' states, respectively, these measurements taken in air-saturated $80 \mathrm{mmol} \mathrm{dm}^{-3}$ glucose solution. At this feed concentration the maximum power generated by the fully 'on' cell was $21 \mu \mathrm{W} \mathrm{cm}{ }^{-2}$ at approximately $1 \mathrm{k} \Omega$ external resistance. By repeated application of a $-0.5 \mathrm{~V}$ potential to maintain the reduced form of the copper in the poly(acrylic acid) layer the cell performance could be maintained for over $48 \mathrm{~h}$.

Another switchable cell has been described (Takeuchi and Amao, 2004), in this case a photo-switchable biofuel cell. They modified a nanocrystalline titanium oxide electrode with zinc chlorin- $\mathrm{e}_{6}$ to act as an electron acceptor from NADH, with glucose oxidation to gluconic acid by glucose dehydrogenase being the initial electron source. A platinum-on-glass cathode was used for oxygen reduction. The cell was illuminated at $100 \mathrm{~mW} \mathrm{~cm}^{-2}$, and achieved currents of up to $6.8 \mu \mathrm{A} \mathrm{cm}^{-2}$ at short circuit and open circuit voltage of $444 \mathrm{mV}$. The maximum power was estimated to be $16 \mathrm{nW} \mathrm{cm}{ }^{-2}$. When the cell was not illuminated, approximately no current or voltage was detected. The cell as described thus requires far more light energy input to activate it than it returns through the consumption of fuel.

A group at the University of Texas at Austin have developed a non-compartmentalised, miniature biofuel cell based on two carbon fibres coated with redox polymer. The polymers (several 
variations have been used) entrap the enzyme and act as electron conductors, connecting glucose oxidase to the anode and one of two oxygen-reducing enzymes to the cathode; laccase (Chen et al., 2001; Mano et al., 2003b; Soukharev et al., 2004) or bilirubin oxidase (Kim et al., 2003b; Mano et al., 2002c, 2003a). In each case the electrodes consist of a $7 \mu \mathrm{m}$ diameter $2 \mathrm{~cm}$ long carbon fibre, each with an active surface area of $0.44 \mathrm{~mm}^{2}$. This fuel cell was developed with the carbon fibres in $1 \mathrm{~mm} \times 1 \mathrm{~mm}$ grooves in a polycarbonate support, with the grooves being $400 \mu \mathrm{m}$ apart. This configuration was modified in recent work (Mano et al., 2003a), where two of the fibres were implanted into a grape, thereby demonstrating operation in a living plant.

The catalytic coating on the carbon fibre electrodes is a hydrogel comprised crosslinked electrostatic adducts of enzyme and conductive polymer containing complexed osmium ions. The composition and structure of the polymer has varied as the biofuel cell has been developed. The objectives of this series of biofuel cells have been explained by (Heller, 2004), who believes that the appropriate scope for their development is as power sources for medium term (of the order of months) implanted biosensors. Many of the performances tabulated in Table 5 are representative of this type of enzyme 'wiring'.

Tsujimura et al. (2002), using the same wiring polymer and complexed osmium-based system as the group at the University of Texas, constructed a single compartment biofuel cell using glassy carbon disc electrodes, bilirubin oxidase and soluble glucose dehydrogenase (sGDH). Cyclic voltammetric studies were also done on a GOx based anode system using the same polymer for comparison. The anodic enzyme (sGDH) was wired using poly(1-vinylimidazole) complexed with Os(4,4'-dimethyl-2,2'-bipyridine $)_{2} \mathrm{Cl}$, and oxidised glucose to gluconate. The cathodic enzyme (BOx) was wired using poly(4-vinylpyridine) complexed with $\mathrm{Os}\left(2,2^{\prime} \text {-bipyridine }\right)_{2} \mathrm{Cl}$ and quaternised with bromoethylamine and reduced oxygen to water. The assembled fuel cell used an electrolyte comprising oxygen-saturated $30 \mathrm{mmol} \mathrm{dm}^{-3}$ MOPS buffer $\mathrm{pH} 7.0$ containing $3 \mathrm{mmol} \mathrm{dm}^{-3} \mathrm{CaCl}_{2}$ (to ensure sGDH function) and $50 \mathrm{mmol} \mathrm{dm}^{-3}$ glucose as anodic substrate. The cell gave an open circuit voltage of $0.44 \mathrm{~V}$ at $25^{\circ} \mathrm{C}$, and a short circuit current density of $0.43 \mathrm{~mA} \mathrm{~cm}^{-2}$ under stirring. The maximum power density achieved was $58 \mu \mathrm{W} \mathrm{cm}{ }^{-2}$ at $0.19 \mathrm{~V}$. This power output is comparable with that obtained by Chen et al. $58 \mu \mathrm{W} \mathrm{cm}{ }^{-2}$ at $0.19 \mathrm{~V}$ (Chen et al., 2001), but the cell voltage is considerably lower. No stability assessments were made on this system, so the variation of the output with time is unknown.

The limiting factor on current generation in this fuel cell system is the reaction rate of bilirubin oxidase (demonstrated by cyclic voltammograms). The cell potential is limited by significant thermodynamic losses, particularly at the anode. The authors suggest that other mediators could be used in the anodic wiring polymer to make the $E^{0 \prime}$ of the electrode more negative in systems using sGDH. This would increase the cell potential. This idea would seem to have been proven correct by the subsequent work by the University of Texas group, who have significantly improved the power and potential demonstrated by their systems by improving the wiring polymers. This paper has also demonstrated that the redox hydrogel based approach to a biofuel cell system is viable for larger electrodes than individual carbon fibres, opening the door to systems that scale the technology up to produce greater current outputs.

A hydrogenase based hydrogen electrode based on a hydrogenase from Thiocapsa roseopersicina has been developed (Morozov et al., 2002). Direct bioelectrocatalytic hydrogen oxidation at an exchange current density slightly greater than that of a platinum electrode was demonstrated with the enzyme directly adsorbed onto carbon filament material, and the enzyme electrode operated at the equilibrium hydrogen potential. The enzyme used still retained half of its activity after half a year of storage with periodical testing. A 'wired' hydrogenase enzyme was also described but this was not as effective (lower exchange current densities and limited to the mediator potential).

Pizzariello et al. (2002) produced a laminar electrode-based biofuel cell that was stable for 30 days of continuous work using a spray printing technology. The anodic enzyme used was GOx, and the cathodic enzyme used was horseradish peroxidase (HRP). $4.0 \%$ enzyme (w.r.t. final weight of composite electrode material) was dissolved in water and graphite powder was then added. The resulting suspension was then mixed thoroughly until the water was evaporated. $0.5 \mathrm{~g}$ of enzyme modified graphite was then resuspended by adding $15 \mathrm{~g}$ of chloroform containing $3.4 \%(\mathrm{w} / \mathrm{w})$ 2-hexadecanone and $0.32 \%(\mathrm{w} / \mathrm{w})$ ferrocene. This suspension was mixed such that it could be sprayed through a mesh screen onto a polymer support. The electrodes produced by this method are thin laminar structures on an inert polymer support sheet. Electrical connection to the electrodes was ensured by the use of a silver track $1.5 \mathrm{~mm} \times 2 \mathrm{~cm}$ preprinted onto the polymeric support. The electrodes each had $0.032 \mathrm{~cm}^{2}$ surface area and were separated in the fuel cell by a $0.02 \mathrm{~mm}$ thick Nafion membrane. The text and figures in the paper are somewhat contradictory about the fuel cell performance in respect to cell voltage generated: the abstract indicates an open circuit voltage of $0.22 \mathrm{~V}$, a figure showing the cell voltage with external loads suggests open circuit voltage tending to ca. $0.06 \mathrm{~V}$ and the body of the text indicates that $0.31 \mathrm{~V}$ was obtained with the concentrations of glucose (anodic substrate) and hydrogen peroxide (cathodic substrate) at $1 \mathrm{mmol} \mathrm{dm}^{-3}$, a level demonstrated to be sufficient to saturate the enzymes on both electrodes. Glucose and hydrogen peroxide were initially present in $1 \mathrm{mmol} \mathrm{dm}^{-3}$ concentrations in their respective compartments. During continuous operation of the fuel cell the substrate levels were monitored and restored to original concentrations every $30 \mathrm{~h}$. Between batch addition of fresh electrolyte the voltage decreased reversibly by $10.5 \%$. The system produced an almost stable power output for 15 days operating on glucose of $0.15 \mu \mathrm{W} \mathrm{cm}^{-2}$ at $0.021 \mathrm{~V}$. (Maximum potential decreased by $2.32 \%$ over this period.) Without halting the system the anodic feed solution was then changed to hydrolysed corn syrup ( $1.75 \%$ in $0.1 \mathrm{~mol} \mathrm{dm}^{-3}$ potassium phosphate buffer $\mathrm{pH} 7.0$ ). This increased the potential output by $5.8 \%$, and exhibited similar stability over 15 days (2.5\% drop in voltage after 15 days).

Comparison of the last fuel cell described here with the glucose $/ \mathrm{H}_{2} \mathrm{O}_{2}$ biofuel cell using MP-11 as the cathodic catalyst (Willner et al., 1998b) is difficult due to the errors in the paper. The authors give the open circuit voltage for their sys- 
tem as $0.31 \mathrm{~V}$ stable with an external resistance greater than ca. $50 \mathrm{k} \Omega$, so it seems likely that the value of $0.32 \mathrm{~V}$ reported in the body of the text is the correct one. Interestingly this is reported as becoming stable only with an external resistance greater than $600 \mathrm{k} \Omega$. The biofuel cell using MP-11 was found to have an optimum power output with an external resistance of $3 \mathrm{k} \Omega$. Pizzariello et al. do not give an optimum situation for their cell, just the performance at $100 \mathrm{k} \Omega$ external resistance. Unfortunately neither paper gives quite enough information that the cause(s) of the differences in performance can be explained.

\section{Conclusions}

\subsection{Review of progress}

Palmore and Whitesides (1994) have identified the overall objective of biofuel cell research as to establish whether biofuel cells are real contenders for practical use. It was noted that the stability and activity of a hydrogen-oxidising anode provide a high performance; hence it is difficult for biochemical fuels to compete with the relatively high power density of gaseous hydrogen (Tsujimura et al., 2001a) and liquid fuels such as methanol. Biofuel cell research has shown success in investigating systems based on more complex fuel molecules (Palmore and Kim, 1999). Recent experiments have demonstrated the possibility of exceeding the hydrogen oxidation activity of platinum (Morozov et al., 2002), at least in the short-term.

Much of the work in the past decade has focused on development of the chemistries of the electrode-enzyme-substrate interactions. This research has resulted in the identification of more robust and active microbes (Chaudhuri and Lovley, 2003; Palmore and Kim, 1999) and enzymes (Mano et al., 2002a), the development of mediators with potentials very close to those of the enzyme active site systems (Tsujimura et al., 2001a, 2003) and improved mediator arrangements: structured electron transfer pathways (Mano et al., 2002c; Zayats et al., 2002a) and mediators integrated into the electrode (Mano et al., 2003b; Park and Zeikus, 2002). Improved electron transfer mechanisms have been developed that can successfully compete with oxygen as a terminal electron acceptor, allowing oxidising enzyme electrodes to function in oxygenated solutions (Chen et al., 2001; Katz et al., 1999c). This is an essential step in producing practical fuel cells that do not require continuous purging of the anode compartment with inert gas, and reduces concern about the oxygen barrier properties of a membrane between compartments to the extent where membraneless biofuel cells have been produced.

In many cases, the operational loss of mediator species has been eliminated by entrapment of the mediator either into the electrode (Park and Zeikus, 2003), against the electrode (Akers et al.) or into a structured electron transfer path on the electrode (Tsujimura et al., 2002). Mediator immobilisation is a familiar problem in biosensor design. Immobilisation strategies should significantly reduce the cost of biofuel cells and improve their longer term performance, as loss of mediator has been a strongly limiting factor, particularly for NAD-dependent enzyme systems (although the tendency of $\mathrm{NAD}(\mathrm{H})$ to hydrolyse has not been addressed).

The potential for lowering the cost of suitable enzymes through genetic engineering (Palmore and Whitesides, 1994) has so far been largely ignored in favour of research to discover more efficient enzymes. While several improved enzymes have been discovered, genetic enzyme modification may eventually enable wider commercialisation of biofuel cells.

More efficient biofuel cell designs allowing operation without a membrane (Chen et al., 2001; Park and Zeikus, 2003; Tender et al., 2002) or in a membrane/electrode assembly (Akers and Minteer, 2003), that have been recently reported, have helped the move of biofuel cells towards portable and/or remote power applications.

\subsection{A forward look}

If biofuel cells are to find a real world application there is a credibility gap (Fig. 10) that must be bridged. Calabrese Barton et al. (2004) estimated that with a $100 \mathrm{~nm}^{2}$ cross section

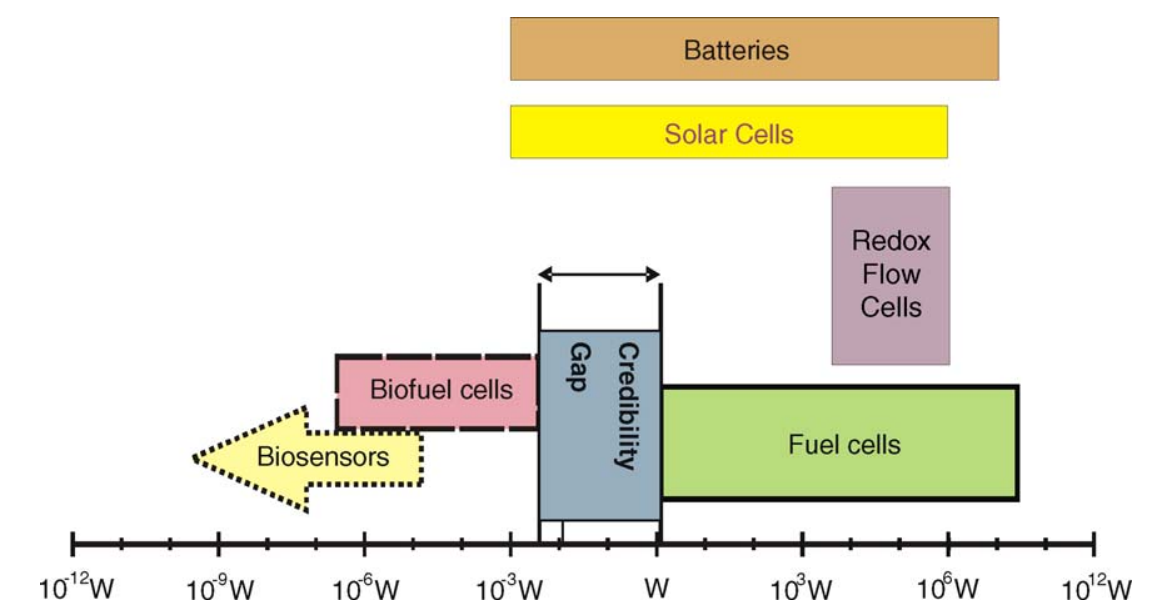

Fig. 10. Approximate power output ranges of biosensors, biofuel cells and inorganic fuel cells, illustrating the scale of the credibility gap challenging the biofuel cell researcher. 
enzyme with $500 \mathrm{e}^{-} \mathrm{s}^{-1}$ turnover a monolayer thickness generates approximately $80 \mu \mathrm{A} \mathrm{cm}^{-2}$, whereas a practical biofuel cell will require ca. $10 \mathrm{~mA} \mathrm{~cm}^{-2}$; an increase of over two orders of magnitude. Cell voltage also tends to be lower in biofuel cells than in other fuel cells such as $\left(\mathrm{H}_{2} \mid\right.$ air, $\mathrm{CH}_{3} \mathrm{OH} \mid$ air ones $)$. The result is a low power output per unit electrode area. Many applications require a power output in the range $10-100 \mathrm{~W} \mathrm{~cm}^{-2}$. In order to meet these challenges, further work should aim to increase not only the immediate efficiency of the biofuel cell electrode (by improving the chemistry), but also to consider engineering problems. The need for increased catalyst loadings while maintaining catalyst utilisation levels is paramount. Demonstration biofuel cell systems, tailored to specific applications will be important in providing confidence in this emerging technology.

With enzymatic cells in particular the lifetime of the biocatalysts, currently of the order of a month in favourable cases, needs to be increased to the order of at least a year to find commercial favour.

The literature on biofuel cells has a tendency to focus on the chemistry of electron transfer at an electrode/electrolyte interface but the information required to truly evaluate system performance, in terms of energy output per unit size, is rarely present. In particular, the dimensions and complete geometry of biofuel cells are rarely considered. Often, cell design descriptions are incomplete e.g. giving only a volume of each compartment. Electrode separations, dimensions and most crucially areas really need to be determined and presented to fully describe a system. The surface areas of high area electrodes such as RVC or carbon felt are rarely given; instead the superficial dimensions are presented. Pore size, mass and dimensions can be used to estimate an area (if all three are provided), but an adsorption-based test could be used to determine an accurate figure.

For enzyme-based systems the areas of electrodes are usually small - up to a few centimetres - and hence the power output is not large enough for many potential applications. Several of the newer electron transfer systems are limited by the turnover rate of the enzyme, a hard limit to vary (variation by genetic manipulation may be possible). To achieve higher currents the enzyme loading on the electrode therefore has to be increased and the simplest way to achieve this is to use a higher area electrode. High specific surface area electrode materials have been used, but the 'obvious' expedient of using a larger electrode has not. This is a pity as it has left investigation of scale-up problems in biofuel cell systems unexplored. Research on small electrodes is worthwhile, especially since proposed in vivo biofuel cell applications demand a small but efficient electrode, but that there is a gap in the research where scaled up systems could be attempted.

With microbial biofuel cell systems larger electrodes have been employed with some success (e.g. Tender et al., 2002), in part because of the comparatively simple challenge of electrochemically connecting larger numbers of microbes to an electrode. Even so there is the potential for interesting research into increasing the size and throughput of any system intended to generate power or remediate a waste stream, and discovery of what the implications of the increased load are.
For practical systems it is necessary to know how the biofuel cell will perform over its lifetime. Indeed, it is necessary to determine what that lifetime will be. Microbial systems are 'live' and are therefore self-renewing so long as steady state can be maintained, but enzymatic systems are based on a catalyst protein that is certain to degrade over time. The rate and relevant factors of this degradation need to be well understood in a biofuel cell, but essential stability tests on enzyme-based systems are often poorly done - tests often show stability over a $24 \mathrm{~h}$ period in the $>98 \%$ region but do not explore it further. At one time this would have been an achievement, but as the field progresses it becomes more important to extend the duration of these tests to determine what the limits of a system are. Also, stability tests are often conducted in an unsteady state system in which an initial supply of substrate is consumed. This makes it impossible to separate the intrinsic lifetime of the electrolytic system and the effects of substrate and product concentrations. Stability tests need to be conducted in a steady state system to ensure stable substrate concentrations so that the effects seen are solely due to the action of the electroactive system. A flowing fed system is one way of achieving this. Stability also needs to be tested in a consistent way - a test that considers the operation of a system under load continuously for a week with a constant supply of substrate will have a different outcome from one which measures the performance of the system under test conditions for an hour each day and stores the electrode in a refrigerator in between.

As observed by Palmore and Whitesides in 1994, the energy budget of the biofuel cell system as a whole also needs to be considered (Palmore and Whitesides, 1994). If the final design is not a battery relying on diffusion to transport substrate and components of the reaction system to and from the electrode, then the energy demands of any pumps in place must be considered: a biofuel cell that requires more energy to pump the fuel than it can itself develop is of little use unless an alternate source for the pumping energy can be found.

It can also be observed from the literature that glucose oxidase has been used as a model system for a large body of work. While this is entirely appropriate for any design that is proposed to eventually operate in vivo as a glucose/oxygen cell, it is not necessarily the best substrate to select in trying to develop any other actual biofuel cell application. Enzyme based systems can only fully oxidise glucose by using several enzymes, and the product of the first stage of the oxidation has the potential to polymerise and foul the electrode surface. If an applied biofuel cell is to be demonstrated then other substrates may lend themselves to easier handling. While the well understood model enzyme system is ideal for developing further understanding of the electrical connection of enzymes to electrodes, the development of biofuel cells as a whole body of work might be better served by also studying enzyme-substrate systems that lend themselves to solving the engineering side of the equation.

Methanol and ethanol are readily obtainable, have good energy density and are miscible with water, making the transport issues easier to handle. This system has been studied by some groups, and is a good model for $\mathrm{NAD}(\mathrm{H})$ mediated enzymatic catalysis. Given the hydrolysis of $\mathrm{NAD}(\mathrm{P})(\mathrm{H})$ an FAD based 
Table 6

Potential biofuel cells and applications

\begin{tabular}{|c|c|c|}
\hline Fuel cell & Fuel & Application \\
\hline In vivo power supply & Blood glucose and oxygen & Pacemaker, glucose sensor, prosthetic valve actuator power supply \\
\hline Trans-cutaneous power socket & Blood glucose and oxygen & Variety of low power electronic devices \\
\hline Waste remediation & Process residues & Remediation of process wastes with power recovery (microbial fuel cell) \\
\hline Waste remediation & Urine & Use of wastes for power generation in remote areas \\
\hline Portable power cell & Alcohol & $\begin{array}{l}\text { Portable power supply for mobile telephones or other consumer electronics. Instant recharge } \\
\text { times, lifetime of order of a month between replacements. No precious metals required so } \\
\text { readily recyclable or disposable }\end{array}$ \\
\hline Biosensors & Target molecule & $\begin{array}{l}\text { Can act as a specific biosensor (if enzyme based) or a non-specific one if microbe based. The } \\
\text { latter has a potentially indefinite lifetime }\end{array}$ \\
\hline Static power generation & Cellulosic materials & $\begin{array}{l}\text { Potentially lignocellulosic materials (e.g. Corn stalks, wood) could be broken down and used } \\
\text { to directly generate power sustainably }\end{array}$ \\
\hline Static power generation & Sewage & $\begin{array}{l}\text { Sewage digesting bacteria have been demonstrated to be capable of generating electricity, and } \\
\text { the biological oxygen demand of the fuel itself could serve to maintain a system in an } \\
\text { anaerobic state, but the levels of power for a practical system have not yet been demonstrated }\end{array}$ \\
\hline Static power generation & Marine sediment & $\begin{array}{l}\text { The biofuel cell demonstrated by Tender et al. is almost immediately applicable to providing } \\
\text { long-term power to remote marine electronics }\end{array}$ \\
\hline Mobile power generation & Organic materials & Start and forget gastrobot operations, if suitable food-locating behaviours can be programmed \\
\hline
\end{tabular}

alcohol consuming cell would seem to be a good potential target.

Table 6 sets out some potential applications for biofuel cells that could be developed. Of these, the most likely to "come of age' in the near future are implantable power supplies on a limited scale based on the 'two fibre' biofuel cell design (Mano et al., 2003a), biosensors that sustain themselves on nutrient content extracted from the sampled medium (Kim et al., 2003a), and portable power cells based on the recent development of an MEA configured biofuel cell (Minteer et al., 2003). The latter two of these chiefly require scaling up before they are ready for practical use, with other applications still requiring some further small scale testing. The 'two fibre' design, intended for implantation may be usable without scale-up once it can be demonstrated in vivo, as it already produces an appropriate amount of power for some of its foreseen applications. It is understood that a biofuel cell-based glucose monitoring system has been submitted by Therasense for FDA tests in the USA (2005) related to this work.

Biofuel cells have been developed from an almost purely chemical viewpoint for some time, often in the context of offshoots from biosensor technology. Problems of level and stability of total power output have too often been neglected, with test systems being very small scale, and often set up with an initial load of fuel that is allowed to deplete, placing an intrinsic limit on output duration. For several demonstrated designs the next challenge will be to produce larger devices that have real-world applications, and (especially for enzyme systems) to demonstrate that they can remain productive for longer time-scales (days rather than hours, then weeks rather than days and up to months and years before many applications can be realised).

Successful commercial biofuel cell development requires a 'chemical engineering' approach to design. Research into defining the reaction environment needs to be conducted so that models of system behaviour can be created, validated and employed. Necessary elements in this research include temperature variation, pressure, fluid flow, mass transport (of nutrients, wastes and by-products) and reactant conversion. Once these elements are considered it should become possible to design a biofuel cell as a unit operation that can be employed as a part of a larger process.

\section{Acknowledgements}

The authors are grateful to DSTL and EPSRC for the award of a CASE studentship to RAB.

\section{References}

Akers, N.L., Minteer, S.D., 2003. Preprint Pap. Am. Chem. Soc. Div. Fuel Chem. 48 (2), 895

Akers, N.L., Moore, C.M., Minteer, S.D., 2005. Electrochim. Acta 50 (12), 2521-2525.

Allen, R.M., Bennetto, H.P., 1993. Appl. Biochem. Biotechnol. 39, 27-40.

Armstrong, F.A., Wilson, G.S., 2000. Electrochim. Acta 45 (15-16), 2623-2645.

Aston, W.J., Turner, A.P.F., 1984. Biotechnol. Genetic Eng. Rev. 1, 89-120.

Barton, S.C., Pickard, M., Vazquez-Duhalt, R., Heller, A., 2002. Biosens. Bioelectron. 17 (11-12), 1071-1074.

Bennetto, H.P., Stirling, J.L., Tanaka, K., Vega, C.A., 1983. Biotechnol. Bioengin. 25 (2), 559-568.

Bianco, P., Haladjian, J., Bourdillon, C., 1990. J. Electroanal. Chem. 293 (1-2), 151-163.

Calabrese Barton, S., Gallaway, J., Atanassov, P., 2004. Chem. Rev. 104 (10), 4867-4886.

Chaudhuri, S.K., Lovley, D.R., 2003. Nat. Biotechnol. 21 (10), 1229-1232.

Chen, T., Barton, S.C., Binyamin, G., Gao, Z.Q., Zhang, Y.C., Kim, H.H., Heller, A., 2001. J. Am. Chem. Soc. 123 (35), 8630-8631.

Choi, Y., Jung, E., Kim, S., Jung, S., 2003a. Bioelectrochemistry 59 (1-2), $121-127$

Choi, Y., Kim, N., Kim, S., Jung, S., 2003b. Bull. Korean Chem. Soc. 24 (4), 437-440.

Cohen, B., 1931. J. Bacteriol. 21, 18.

Cooney, M.J., Roschi, E., Marison, I.W., Comninellis, C., vonStockar, U., 1996. Enzyme Microb. Technol. 18 (5), 358-365.

Cosnier, S., 1999. Biosens. Bioelectron. 14 (5), 443-456.

Das, D., Veziroglu, T.N., 2001. Int. J. Hydrogen Energy 26 (1), 13-28.

Divisek, J., Emonts, B., 2003. Energy storage via electrolysis/fuel cells. In: Vielstich, W., Lamm, A., Gasteiger, H.A. (Eds.), Handbook of Fuel 
Cells-Fundamentals, Technology and Applications, Fundamentals and Survey of Systems, vol. 1. Wiley, Chichester, UK, pp. 416-431.

Galvani, L., 1791. De bononiensi scientiarum et artium instituto atque academia Comentarrii 7, 363-418.

Gil, G.C., Chang, I.S., Kim, B.H., Kim, M., Jang, J.K., Park, H.S., Kim, H.J., 2003. Biosens. Bioelectron. 18 (4), 327-334.

Gileadi, E., 1993. Electrode Kinetics for Chemists, Chemical Engineers and Materials Scientists. VCH Publishers, Inc., New York.

Gregg, B.A., Heller, A., 1991a. J. Phys. Chem. 95 (15), 5970-5975.

Gregg, B.A., Heller, A., 1991b. J. Phys. Chem. 95 (15), 5976-5980.

Grove, W.R., 1839. Philos. Mag. Ser. 3 (14), 127.

Haas, O., Holzer, F., Müller, K., Müller, S., 2003. Metal/air batteries: the zinc/air case. In: Vielstich, W., Lamm, A., Gasteiger, H.A. (Eds.), Handbook of Fuel Cells-Fundamentals, Technology and Applications. Fundamentals and Survey of Systems, vol. 1. Wiley, Chichester, UK, pp. 382-408.

Habermuller, L., Mosbach, M., Schuhmann, W., 2000. Fresen. J Anal. Chem. 366 (6-7), 560-568.

Heller, A., 1992. J. Phys. Chem. 96 (9), 3579-3587.

Heller, A., 2004. Phys. Chem. Chem. Phys. 6 (2), 209-216.

Higgins, I.J., Hill, H.A.O., 1985. Essays Biochem. 21, 119-145.

Ieropolous, I., Melhuish, C., Greenman, J., 2004. Energetically autonomous robots, Proceedings of the Eighth Intelligent Autonomous Systems Conference (IAS-8), Amsterdam, pp. 128-135.

Ikeda, T., Kano, K., 2003. Biochim. Biophys. Acta Proteins Proteomics 1647 (1-2), 121-126.

Ikeda, T., Kano, K., 2001. J. Biosci. Bioeng. 92 (1), 9-18.

Kano, K., Ikeda, T., 2003. Electrochemistry 71 (2), 86-99.

Kano, K., Ikeda, T., 2000. Anal. Sci. 16 (10), 1013-1021.

Katz, E., Buckmann, A.F., Willner, I., 2001. J. Am. Chem. Soc. 123 (43), 10752-10753.

Katz, E., Filanovsky, B., Willner, I., 1999a. New J. Chem. 23 (5), 481-487.

Katz, E., Riklin, A., Heleg-Shabtai, V., Willner, I., Buckmann, A.F., 1999 b. Anal. Chim. Acta 385 (1-3), 45-58.

Katz, E., Shipway, A.N., Willner, I., 2003. Biochemical fuel cells. In: Vielstich, W., Gasteiger, H.A., Lamm, A. (Eds.), Handbook of Fuel Cells-Fundamentals, Technology and Applications, Fundamentals and Survey of Systems, vol. 1. John Wiley \& Sons, Ltd., Hoboken, NJ, pp. 355-381.

Katz, E., Willner, I., 2003. J. Am. Chem. Soc. 125 (22), 6803-6813.

Katz, E., Willner, I., Kotlyar, A.B., 1999c. J. Electroanal. Chem. 479 (1), 64-68.

Kelly, I., 2003. Robotica 21, 399-406.

Kelly, I., Melhuish, C., 2001. Slugbot: a robot predator. In: European Conference on Artificial Life, Prague.

Kim, B.H., Chang, I.S., Gil, G.C., Park, H.S., Kim, H.J., 2003a. Biotechnol. Lett. 25 (7), 541-545.

Kim, H.H., Mano, N., Zhang, X.C., Heller, A., 2003b. J. Electrochem. Soc. 150 (2), A209-A213.

Kim, H.J., Hyun, M.S., Chang, I.S., Kim, B.H., 1999. J. Microbiol. Biotechnol. 9 (3), 365-367.

Kim, H.J., Park, H.S., Hyun, M.S., Chang, I.S., Kim, M., Kim, B.H., 2002a. Enzyme Microb. Technol. 30 (2), 145-152.

Kim, J.K., Cho, J.H., Lee, J.S., Hahm, K.S., Park, D.H., Kim, S.W., 2002 b. Appl. Biochem. Biotechnol. 98, 753-764.

Kim, N., Choi, Y., Jung, S., Kim, S., 2000a. Bull. Korean Chem. Soc. 21 (1), 44-48.

Kim, N., Choi, Y., Jung, S., Kim, S., 2000b. Biotechnol. Bioeng. 70 (1), 109-114.

Kosaric, N., Velikonja, J., 1995. FEMS Microbiol. Rev. 16 (2-3), 111-142.

Kreysa, G., Sell, D., Kraemer, P., 1990. Berichte der Bunsengesellschaft fuer Physikalische Chemie 94 (9), 1042-1045.

Larminie, J., Dicks, A., 2000. Fuel Cell Systems Explained, 1st ed. John Wiley \& Sons Ltd., Chichester.

Maness, P.-C., Weaver, P.F., 1999. Biological h2 from fuel gases and from h2o. In: 1999 U.S. DOE Hydrogen Program Review.

Maness, P.C., Weaver, P.F., 1994. Appl. Biochem. Biotechnol. 45-46, 395-406.
Mano, N., Heller, A., 2003. J. Electrochem. Soc. 150 (8), A1136-A1138.

Mano, N., Kim, H.H., Heller, A., 2002a. J. Phys. Chem. B 106 (34), 8842-8848.

Mano, N., Kim, H.H., Zhang, Y.C., Heller, A., 2002b. J. Am. Chem. Soc. 124 (22), 6480-6486.

Mano, N., Mao, F., Heller, A., 2003a. J. Am. Chem. Soc. 125 (21), 6588-6594.

Mano, N., Mao, F., Heller, A., 2002c. J. Am. Chem. Soc. 124 (44), 12962-12963.

Mano, N., Mao, F., Shin, W., Chen, T., Heller, A., 2003b. Chem. Commun. 4, 518-519.

Mao, F., Mano, N., Heller, A., 2003. J. Am. Chem. Soc. 125 (16), $4951-$ 4957.

Minteer, S.D., Akers, N.L., Thomas, T.J., Moore, C.M., 2003. Abstr. Papers Am. Chem. Soc. 225 (1-2).

Mitsos, A., Palou-Rivera, I., Barton, P.I., 2004. Ind. Eng. Chem. Res. 43 (1), 74-84.

Morozov, S.V., Karyakina, E.E., Zorin, N.A., Varfolomeyev, S.D., Cosnier, S., Karyakin, A.A., 2002. Bioelectrochemistry 55 (1-2), 169-171.

Niessen, J., Schroder, U., Scholz, F., 2004. Electrochem. Commun. 6 (9), 955-958.

O'Neill, H., Woodward, J., 2000. Construction of a bio-hydrogen fuel cell: utilisation of environmental sources of carbohydrates. In: DARPA Advanced Energy Technologies Energy Harvesting Program, Arlington, VA.

Palmore, G.T.R., 2004. Trends Biotechnol. 22 (3), 99-100.

Palmore, G.T.R., Bertschy, H., Bergens, S.H., Whitesides, G.M., 1998. J. Electroanal. Chem. 443 (1), 155-161.

Palmore, G.T.R., Kim, H.-H., 1999. J. Electroanal. Chem. 464, 110-117.

Palmore, G.T.R., Whitesides, G.M., 1994. Microbial and enzymatic biofuel cells. In: Himmel, E. (Ed.), Enzymatic Conversion of Biomass for Fuels Production, vol. 566. American Chemical Society, pp. 271-290.

Park, D.H., Kim, S.K., Shin, I.H., Jeong, Y.J., 2000. Biotechnol. Lett. 22 (16), 1301-1304.

Park, D.H., Zeikus, J.G., 2000. Appl. Environ. Microbiol. 66 (4), 1292-1297.

Park, D.H., Zeikus, J.G., 2002. Appl. Microbiol. Biotechnol. 59 (1), 58-61.

Park, D.H., Zeikus, J.G., 2003. Biotechnol. Bioeng. 81 (3), 348-355.

Park, H.S., Kim, B.H., Kim, H.S., Kim, H.J., Kim, G.T., Kim, M., Chang, I.S., Park, Y.K., Chang, H.I., 2001. Anaerobe 7 (6), 297-306.

Pizzariello, A., Stred'ansky, M., Miertus, S., 2002. Bioelectrochemistry 56 (1-2), 99-105.

Potter, M.C., 1910. Proceedings of the Royal Society B, vol. 84, p. 260.

Quinn, C.A.P., Connor, R.E., Heller, A., 1997. Biomaterials 18 (24), $1665-1670$.

Rabaey, K., Boon, N., Siciliano, S.D., Verhaege, M., Verstraete, W., 2004. Appl. Environ. Microbiol. 70 (9), 5373-5382.

Rabaey, K., Lissens, G., Siciliano, S.D., Verstraete, W., 2003. Biotechnol. Lett. 25, 1531-1535.

Schroder, U., Niessen, J., Scholz, F., 2003. Angew. Chem. Int. Ed. 42 (25), 2880-2883.

Seon, Y.H., Lee, C.G., Park, D.H., Hwang, K.Y., Joe, Y.I., 1993. Biotechnol. Lett. 15 (12), 1275-1280.

Shukla, A.K., Suresh, P., Berchmans, S., Rajendran, A., 2004. Curr. Sci. 87 (4), 455-468.

Soukharev, V., Mano, N., Heller, A., 2004. J. Am. Chem. Soc. 126 (27), 8368-8369.

Takeuchi, Y., Amao, Y., 2004. J. Jpn. Petrol. Inst. 47 (5), 355-358.

Tender, L.M., Reimers, C.E., Stecher, H.A., Holmes, D.E., Bond, D.R., Lowy, D.A., Pilobello, K., Fertig, S.J., Lovley, D.R., 2002. Nat. Biotechnol. 20 (8), 821-825.

Tsujimura, S., Fujita, M., Tatsumi, H., Kano, K., Ikeda, T., 2001a. Phys. Chem. Chem. Phys. 3 (7), 1331-1335.

Tsujimura, S., Wadano, A., Kano, K., Ikeda, T., 2001b. Enzyme Microb. Technol. 29 (4-5), 225-231.

Tsujimura, S., Kano, K., Ikeda, T., 2002. Electrochemistry 70 (12), 940942.

Tsujimura, S., Kawaharada, M., Nakagawa, T., Kano, K., Ikeda, T., 2003. Electrochem. Commun. 5 (2), 138-141. 
Van Dijk, C., Laane, C., Veeger, C., 1985. Recueil Des Travaux Chimiques Des Pays-Bas-Journal of the Royal Netherlands Chemical Society 104 (10), 245-252.

Vielstich, W., Lamm, A., Gasteiger, H.A. (Eds.), 2003. Handbook of Fuel Cells-Fundamentals Technology and Applications, Fundamentals and Survey of Systems, vol. 1. Wiley, Chichester, UK.

Wilkinson, S., 2000. Gastronome-a pioneering food powered mobile robot. In: M.H. Hamza (Ed.), IASTED International Conference on Robotics and Applications, Acta Pr., Honolulu, Hawaii.

Willner, I., Arad, G., Katz, E., 1998a. Bioelectrochem. Bioenerget. 44 (2), 209-214.

Willner, I., HelegShabtai, V., Blonder, R., Katz, E., Tao, G.L., 1996. J. Am. Chem. Soc. 118 (42), 10321-10322.

Willner, I., Katz, E., Patolsky, F., Buckmann, A.F., 1998b. J. Chem. Soc., Perkin Trans. 2 (8), 1817-1822.
Willner, I., Katz, E., Willner, B., 1997. Electroanalysis 9 (13), 965977.

Wingard, L.B., Shaw, C.H., Castner, J.F., 1982. Enzyme Microb. Technol. 4 (3), 137-142.

Wong, T., Schwaneberg, U., 2003. Curr. Opin. Biotechnol. 14 (6), 590596.

Woodward, J., Mattingly, S.M., Danson, M., Hough, D., Ward, N., Adams, M., 1996. Nat Biotechnol. 14, 872-874.

Yagishita, T., Sawayama, S., Tsukahara, K., Ogi, T., 1999. J. Biosci. Bioeng. 88 (2), 210-214.

Zayats, M., Katz, E., Willner, I., 2002a. J. Am. Chem. Soc. 124 (49), 14724-14735.

Zayats, M., Katz, E., Willner, I., 2002b. J. Am. Chem. Soc. 124 (10), 2120-2121. 